\title{
Contributions of biomass-burning, urban, and biogenic emissions to the concentrations and light-absorbing properties of particulate matter in central Amazonia during the dry season
}

\author{
Suzane S. de Sá ${ }^{1}$, Luciana V. Rizzo ${ }^{2}$, Brett B. Palm ${ }^{3, \text { a }}$, Pedro Campuzano-Jost ${ }^{3}$, Douglas A. Day ${ }^{3}$, Lindsay D. Yee ${ }^{4}$, \\ Rebecca Wernis ${ }^{5}$, Gabriel Isaacman-VanWertz ${ }^{4, b}$, Joel Brito ${ }^{6, c}$, Samara Carbone ${ }^{6, d}$, Yingjun J. Liu ${ }^{1, e}$, \\ Arthur Sedlacek $^{7}$, Stephen Springston ${ }^{7}$, Allen H. Goldstein ${ }^{4}$, Henrique M. J. Barbosa ${ }^{6}$, M. Lizabeth Alexander ${ }^{8}$, \\ Paulo Artaxo ${ }^{6}$, Jose L. Jimenez ${ }^{3}$, and Scot T. Martin ${ }^{1,9}$ \\ ${ }^{1}$ John A. Paulson School of Engineering and Applied Sciences, Harvard University, Cambridge, MA, USA \\ ${ }^{2}$ Department of Environmental Sciences, Universidade Federal de São Paulo, Diadema, São Paulo, Brazil \\ ${ }^{3}$ Department of Chemistry and Cooperative Institute for Research in Environmental Sciences, \\ University of Colorado, Boulder, CO, USA \\ ${ }^{4}$ Department of Environmental Science, Policy, and Management, University of California, \\ Berkeley, CA, USA \\ ${ }^{5}$ Department of Civil and Environmental Engineering, University of California, Berkeley, Berkeley, CA, USA \\ ${ }^{6}$ Institute of Physics, University of São Paulo, São Paulo, Brazil \\ ${ }^{7}$ Brookhaven National Laboratory, Upton, NY, USA \\ ${ }^{8}$ Environmental Molecular Sciences Laboratory, Pacific Northwest National Laboratory, Richland, WA, USA \\ ${ }^{9}$ Department of Earth and Planetary Sciences, Harvard University, Cambridge, MA, USA \\ anow at: Department of Atmospheric Sciences, University of Washington, Seattle, WA, USA \\ ${ }^{b}$ now at: Department of Civil and Environmental Engineering, Virginia Tech, Blacksburg, VA, USA \\ ${ }^{c}$ now at: IMT Lille Douai, Université Lille, SAGE, Lille, France \\ ${ }^{d}$ now at: Agrarian Sciences Institute, Federal University of Uberlândia, Minas Gerais, Brazil \\ ${ }^{e}$ now at: College of Environmental Science and Engineering, Peking University, Beijing, China
}

Correspondence: Scot T. Martin (scot_martin@harvard.edu)

Received: 18 December 2018 - Discussion started: 9 January 2019

Revised: 5 May 2019 - Accepted: 6 May 2019 - Published: 18 June 2019

\begin{abstract}
Urbanization and deforestation have important impacts on atmospheric particulate matter (PM) over Amazonia. This study presents observations and analysis of $\mathrm{PM}_{1}$ concentration, composition, and optical properties in central Amazonia during the dry season, focusing on the anthropogenic impacts. The primary study site was located $70 \mathrm{~km}$ downwind of Manaus, a city of over 2 million people in Brazil, as part of the GoAmazon2014/5 experiment. A high-resolution time-of-flight aerosol mass spectrometer (AMS) provided data on $\mathrm{PM}_{1}$ composition, and aethalometer measurements were used to derive the absorption coefficient $b_{\mathrm{abs}, \mathrm{BrC}}$ of brown carbon $(\mathrm{BrC})$ at $370 \mathrm{~nm}$. Non-refractory $\mathrm{PM}_{1}$ mass concentrations averaged $12.2 \mu \mathrm{g} \mathrm{m}^{-3}$ at the primary study site, dominated by organics $(83 \%)$, followed
\end{abstract}

by sulfate $(11 \%)$. A decrease in $b_{\mathrm{abs}, \mathrm{BrC}}$ was observed as the mass concentration of nitrogen-containing organic compounds decreased and the organic $\mathrm{PM}_{1} \mathrm{O}: \mathrm{C}$ ratio increased, suggesting atmospheric bleaching of the $\mathrm{BrC}$ components. The organic $\mathrm{PM}_{1}$ was separated into six different classes by positive-matrix factorization (PMF), and the mass absorption efficiency $E_{\text {abs }}$ associated with each factor was estimated through multivariate linear regression of $b_{\mathrm{abs}, \mathrm{BrC}}$ on the factor loadings. The largest $E_{\text {abs }}$ values were associated with urban $\left(2.04 \pm 0.14 \mathrm{~m}^{2} \mathrm{~g}^{-1}\right)$ and biomass-burning $(0.82 \pm 0.04$ to $1.50 \pm 0.07 \mathrm{~m}^{2} \mathrm{~g}^{-1}$ ) sources. Together, these sources contributed at least $80 \%$ of $b_{\mathrm{abs}, \mathrm{BrC}}$ while accounting for $30 \%$ to $40 \%$ of the organic $\mathrm{PM}_{1}$ mass concentration. In addition, a comparison of organic $\mathrm{PM}_{1}$ composition between wet and 
dry seasons revealed that only part of the 9-fold increase in mass concentration between the seasons can be attributed to biomass burning. Biomass-burning factor loadings increased by 30 -fold, elevating its relative contribution to organic $\mathrm{PM}_{1}$ from about $10 \%$ in the wet season to $30 \%$ in the dry season. However, most of the $\mathrm{PM}_{1}$ mass $(>60 \%)$ in both seasons was accounted for by biogenic secondary organic sources, which in turn showed an 8-fold seasonal increase in factor loadings. A combination of decreased wet deposition and increased emissions and oxidant concentrations, as well as a positive feedback on larger mass concentrations are thought to play a role in the observed increases. Furthermore, fuzzy $c$-means clustering identified three clusters, namely "baseline", "event", and "urban" to represent different pollution influences during the dry season. The baseline cluster, representing the dry season background, was associated with a mean mass concentration of $9 \pm 3 \mu \mathrm{g} \mathrm{m}^{-3}$. This concentration increased on average by $3 \mu \mathrm{g} \mathrm{m}^{-3}$ for both the urban and the event clusters. The event cluster, representing an increased influence of biomass burning and long-range transport of African volcanic emissions, was characterized by remarkably high sulfate concentrations. The urban cluster, representing the influence of Manaus emissions on top of the baseline, was characterized by an organic $\mathrm{PM}_{1}$ composition that differed from the other two clusters. The differences discussed suggest a shift in oxidation pathways as well as an accelerated oxidation cycle due to urban emissions, in agreement with findings for the wet season.

\section{Introduction}

The Amazon basin has undergone significant urbanization and deforestation in the past decades (Davidson et al., 2012; Martin et al., 2017; van Marle et al., 2017). An understanding of how the composition of atmospheric particulate matter (PM) changes due to anthropogenic activities and how these changes affect PM optical properties is essential for quantifying the global anthropogenic radiative forcing (IPCC, 2013; Sena et al., 2013). Light absorption coefficients, $b_{\mathrm{abs}}$, and their spectral dependence, commonly referred to as the

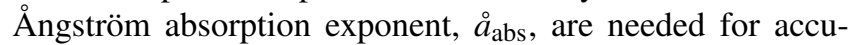
rate interpretation of satellite-retrieved aerosol optical depth (AOD) for climate modeling. Estimates of the mass absorption efficiency $E_{\text {abs }}$ for PM subcomponents are useful for models to estimate optical effects based on PM composition and mass concentrations (Laskin et al., 2015).

Organic material that can efficiently absorb radiation in the near-ultraviolet through the blue end of the visible spectrum, with decreasing absorption efficiency as wavelength increases, is termed "brown carbon" (BrC) (Pöschl, 2003; Andreae and Gelencsér, 2006; Laskin et al., 2015). By comparison, black carbon (BC) absorbs light efficiently throughout the visible spectrum. Although global climate models have typically treated organic PM as purely scattering, several studies have shown that brown carbon can contribute substantially to light absorption by PM, especially in regions affected by biomass-burning and urban emissions (Andreae and Gelencsér, 2006; Ramanathan et al., 2007; Bond et al., 2011; Bahadur et al., 2012; Ma and Thompson, 2012; Feng et al., 2013). In addition to primary emissions of $\mathrm{BrC}$, secondary production of $\mathrm{BrC}$ can occur from the oxidation of non-methane volatile organic compounds (NMVOCs) present in biomass smoke (Saleh et al., 2014) and from atmospheric multiphase reactions involving a wide range of precursor NMVOCs (Nozière et al., 2007; De Haan et al., 2009; Nguyen et al., 2012; Lee et al., 2013; Lin et al., 2014; Powelson et al., 2014). The specific sources, chemical characteristics, and optical properties of $\mathrm{BrC}$ remain largely unconstrained.

Biomass-burning and urban pollution can affect the concentrations, composition, and properties of atmospheric PM. In Amazonia, urban pollution is significant downwind of large cities such as Manaus, Brazil (Kuhn et al., 2010; Martin et al., 2017; Cirino et al., 2018; de Sá et al., 2018). Martin et al. (2017) reported increased concentrations of particles, nitrogen oxides, carbon monoxide, and hydroxyl radicals for in-plume compared to out-of-plume conditions downwind of Manaus. Liu et al. (2016) and de Sá et al. (2017) demonstrated that the Manaus pollution plume shifted the oxidation pathway of isoprene, thereby significantly affecting gasand particle-phase compositions. de Sá et al. (2018) determined that the submicron PM mass concentration increased by up to 3 -fold for polluted compared to background conditions downwind of Manaus during the wet season.

Most biomass burning in Amazonia is related to human activities (Davidson et al., 2012; Artaxo et al., 2013; Aragão et al., 2014; van Marle et al., 2017). Among the main activities are the clearing of land and the burning of waste for several agricultural purposes as well as the burning of wood as fuel (Crutzen and Andreae, 1990; van Marle et al., 2017). Burning events are most frequent in the period of August through October, corresponding to the dry season (Setzer and Pereira, 1991; Artaxo et al., 2013; Martin et al., 2016). These activities can affect the biogeochemical cycles, atmospheric chemistry, precipitation, and climate throughout Amazonia (Crutzen and Andreae, 1990; Andreae et al., 2004; Lin et al., 2006). $\mathrm{PM}_{1}$ mass concentrations typically increase by an order of magnitude between the wet and dry seasons in the Amazon, which has been commonly attributed to the increased biomass-burning emissions (Artaxo et al., 1994, 2013; Holben et al., 1996; Martin et al., 2010b, and references therein). Related increases in $b_{\text {abs }}$ by 1 order of magnitude have also been attributed to biomass burning (Rizzo et al., 2011, 2013; Artaxo et al., 2013). Although black carbon is usually the main light-absorbing component for atmospheric particles smaller than $1 \mu \mathrm{m}\left(\mathrm{PM}_{1}\right)$, absorption by the organic $\mathrm{BrC}$ component of $\mathrm{PM}_{1}$ could also be significant (Rizzo et al., 2013; Wang et al., 2016; Saturno et al., 
2017). Palm et al. (2018) showed that the formation potential of secondary organic $\mathrm{PM}_{1}$ increased by a factor of 1.7 in the dry season compared to the wet season, although biomassburning gases were not dominant precursors in either season. An understanding of the types and optical properties of organic components that may affect $\mathrm{PM}_{1}$ light absorption in the Amazon and elsewhere is still emerging (Laskin et al., 2015).

The study herein investigates the contributions of biomass burning, urban emissions, and biogenic emissions to the composition and optical properties of organic $\mathrm{PM}_{1}$ in central Amazonia during the dry season. Positive-matrix factorization (PMF) of organic mass spectra measured by an aerosol mass spectrometer (AMS) was used to identify component classes of the organic $\mathrm{PM}_{1}$. A fuzzy $c$-means clustering analysis of pollution indicators was employed to identify different conditions at the measurement site, as influenced by biomass-burning and urban emissions. Connections are made between the optical properties of organic $\mathrm{PM}_{1}$, including $b_{\mathrm{abs}, \mathrm{BrC}}$ and $E_{\mathrm{abs}}$, and its component classes. Taken together, these three pieces of analysis allow for insights into the changes in particle concentration, composition, and optical properties associated with the influences of biomassburning and urban pollution downwind of Manaus.

\section{Methodology}

\subsection{Research sites and measurements}

The primary site of this study was called "T3", located $70 \mathrm{~km}$ to the west of Manaus, Brazil, in central Amazonia (Martin et al., 2016; inset of Fig. 1a). The pollution plume from Manaus was primarily westerly in the dry season and was modeled to intercept the T3 site about $60 \%$ of the time (Martin et al., 2017). Analyses of observational data sets have labeled pollution episodes for at least 15 to $30 \%$ of the time (Thalman et al., 2017; Cirino et al., 2018). Auxiliary sites "T0a" and "T2" served as references for background and urban-polluted conditions, respectively, in relation to T3. The T0a site was located at the Amazon Tall Tower Observatory (Andreae et al., 2015), about $150 \mathrm{~km}$ to the northeast of Manaus, and the air masses were typically upwind of the urban region without the influence of Manaus pollution. The T2 site was located $8 \mathrm{~km}$ to the west of Manaus, directly downwind of the city, and air masses were therefore typically heavily polluted at this site. During the dry season, the three sites were also affected by both nearby and long-range-transported biomass-burning emissions. The study period from 15 August to 15 October 2014 corresponded to the second Intensive Operating Period (IOP2) of the GoAmazon2014/5 experiment (Martin et al., 2016).
At the T3 site, mass concentrations of non-refractory $\mathrm{PM}_{1}$ components (organic, sulfate, ammonium, nitrate, and chloride) were measured by a high-resolution time-of-flight AMS (DeCarlo et al., 2006; Sueper, 2018). A detailed description of operation was provided in de Sá et al. (2017). In brief, the AMS was deployed inside a temperature-controlled research container, and ambient data were collected every other $4 \mathrm{~min}$. Data analysis was performed using SQUIRREL (1.56D) and PIKA (1.14G) of the AMS software suite (DeCarlo et al., 2006). The mean composition-dependent collection efficiency was 0.51 (Sect. S1; Fig. S1 in the Supplement) (Middlebrook et al., 2012). Organic and inorganic nitrate concentrations were estimated from the AMS measurements based on the ratio of the signal intensity of $\mathrm{NO}_{2}^{+}$to that of $\mathrm{NO}^{+}$(Sect. S1, Fig. S2 in the Supplement) (Fry et al., 2009, 2013; Farmer et al., 2010). Sulfate measured by the AMS includes contributions from organosulfates (Farmer et al., 2010; Glasius et al., 2018). The oxygen-to-carbon (O : C) and hydrogen-to-carbon $(\mathrm{H}: \mathrm{C})$ ratios of the organic $\mathrm{PM}_{1}$ were calculated following the methods of Canagaratna et al. (2015).

Several other instruments complemented the AMS measurements. Gas- and particle-phase semi-volatile tracers were obtained by a semi-volatile thermal desorption aerosol gas chromatograph (SV-TAG) (Isaacman-VanWertz et al., 2016; Yee et al., 2018), and NMVOCs were obtained by a proton-transfer-reaction time-of-flight mass spectrometer (PTR-ToF-MS) (Jordan et al., 2009; Liu et al., 2016). In addition, measurements of $\mathrm{NO}_{y}, \mathrm{O}_{3}$, particle number, and $\mathrm{CO}$ concentrations were employed in the analyses (Martin et al., 2016). Refractory black carbon (rBC) concentrations were measured by a single particle soot photometer (SP2). Meteorological variables, including temperature, relative humidity, and solar irradiance were also measured. Particle absorption coefficients, $b_{\text {abs }}(\lambda)$, were obtained by a seven-wavelength aethalometer (370, 430, 470, 520, 565, 700, and $880 \mathrm{~nm}$; Magee Scientific, model AE-31) following the methods and corrections of Rizzo et al. (2011). Additional measurements of non-refractory particle composition and concentration from the T0a and T2 sites were made by an aerosol chemical speciation monitor (ACSM) at each site (Ng et al., 2011; Andreae et al., 2015; Martin et al., 2016).

Air-mass back-trajectories were estimated using Hybrid Single-Particle Lagrangian Integrated Trajectory (HYSPLIT4; Draxler and Hess, 1998). Data sets of the S-band radar of the System for Amazon Protection (SIPAM) in Manaus (Machado et al., 2014) provided precipitation data, which allowed to filter out trajectories that intercepted precipitation. The HYSPLIT4 simulations started at $100 \mathrm{~m}$ above T3 and were calculated up to $2 \mathrm{~d}$ back in time for every $12 \mathrm{~min}$ to match with the radar data. Input meteorological data to the simulations were obtained on a grid of $0.5^{\circ} \times 0.5^{\circ}$ from the Global Data Assimilation System (GDAS). Additional information on the back-trajectory calculations and on the radar were described in de Sá et al. (2018). 
(a)

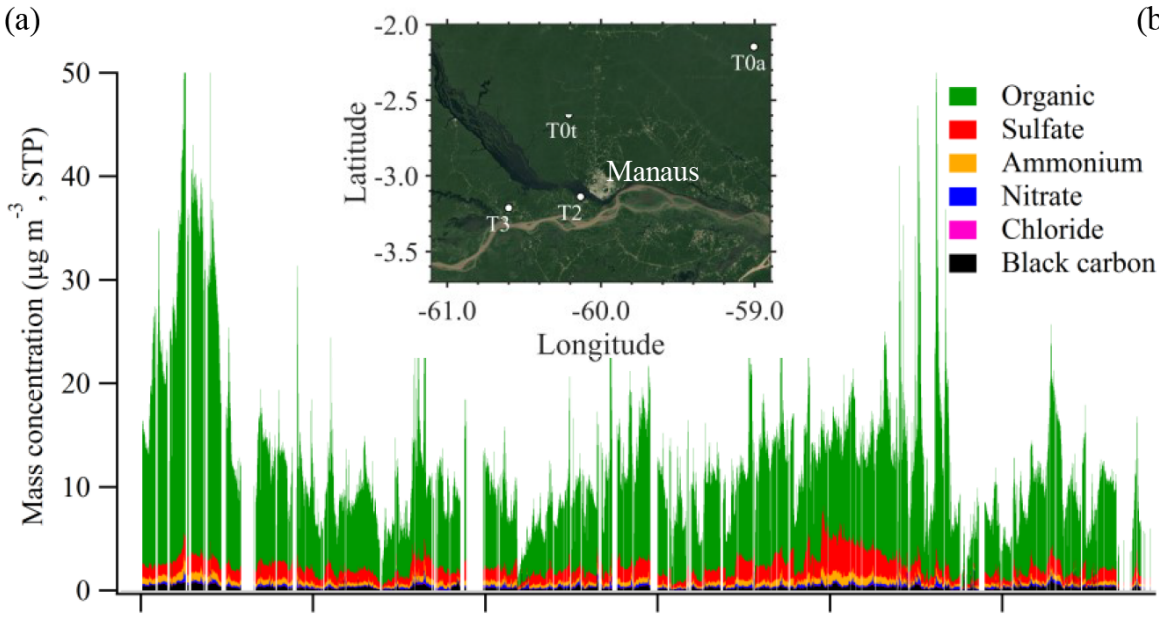

18 Aug 201428 Aug $2014 \quad 7$ Sep $2014 \quad$ 17 Sep $2014 \quad 27$ Sep $2014 \quad 7$ Oct 2014 (b)

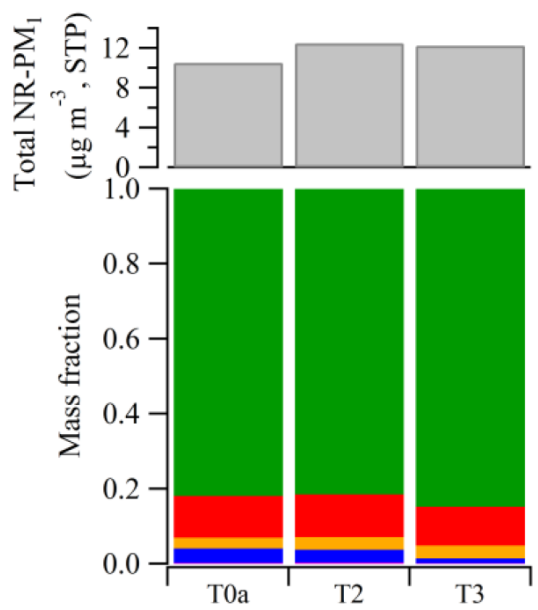

Figure 1. $\mathrm{PM}_{1}$ composition during the dry season from 15 August to 15 October 2014, representing the second Intensive Operating Period (IOP2) of the GoAmazon2014/5 experiment. Results are shown for measurements at T3 in comparison to other sites. (a) $\mathrm{PM}_{1}$ mass concentrations of non-refractory AMS organic, sulfate, ammonium, nitrate, and chloride. Mass concentrations of SP2 refractory black carbon (rBC) are also plotted. rBC refers to the carbon content of graphite-like components that are strongly light absorbing (Pöschl, 2003). (b) Summed mass concentrations (top) and segregated mass fractions (bottom) of the non-refractory species at the T0a, T2, and T3 sites. The inset of panel (a) shows the locations of the relevant research sites for this study. A larger map is shown in Fig. 3. T0a is the Amazon Tall Tower Observatory (Andreae et al., 2015). T2 is a site $8 \mathrm{~km}$ downwind of Manaus, just across the Black River ("Rio Negro") (Cirino et al., 2018). Measurements at T0a and T2 were made by an aerosol chemical speciation monitor (ACSM). Concentrations in both panels were adjusted to standard temperature $(273.15 \mathrm{~K})$ and pressure $\left(10^{5} \mathrm{~Pa}\right)(\mathrm{STP})$.

\subsection{Brown carbon light absorption}

The analysis partitioned the total absorption $b_{\mathrm{abs}}(\lambda)$ measured by the aethalometer between $\mathrm{BrC}$ and $\mathrm{BC}$ contributions as follows:

$b_{\mathrm{abs}}=b_{\mathrm{abs}, \mathrm{BrC}}+b_{\mathrm{abs}, \mathrm{BC}}$.

The dependence on wavelength was expressed by the absorption Ångström exponent $\left(\stackrel{\circ}{a}_{\text {abs }}\right)$ as follows:

$\stackrel{\circ}{a b s}_{\text {abs }}\left(\lambda_{1}, \lambda_{2}\right)=-\frac{\log _{10}\left[b_{\mathrm{abs}}\left(\lambda_{1}\right) / b_{\mathrm{abs}}\left(\lambda_{2}\right)\right]}{\log _{10}\left(\lambda_{1} / \lambda_{2}\right)}$.

For the characterization of $\mathrm{BrC}$ absorption, the value of at $370 \mathrm{~nm}$ was sought. To calculate $b_{\mathrm{abs}, \mathrm{BrC}}(370)$, an assumption has to be made about the spectral dependency of $\mathrm{BC}$

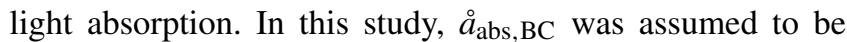
wavelength independent, and $\stackrel{\circ}{a b s, B C}_{\text {abs }}(700,880)$ was calculated for each sample based on $b_{\mathrm{abs}}$ at the wavelengths 700 and $880 \mathrm{~nm}$ (Eq. 2), assuming absorption to be insignificant for $\mathrm{BrC}$ and dominated by $\mathrm{BC}$ in this spectral range. Calculations of $b_{\mathrm{abs}, \mathrm{BrC}}(370)$ using alternative treatments to retrieve $\stackrel{\circ}{a}_{\text {abs,BC }}$ were also carried out. These treatments

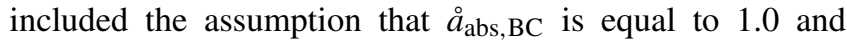
wavelength-independent (e.g., Yang et al., 2009), or the assumption that $\stackrel{\circ}{a}_{\mathrm{abs}, \mathrm{BC}}$ has a spectral dependency itself (Wang et al., 2016; Saturno et al., 2018a). The results from these different treatments correlated with one another $\left(R^{2}>0.9\right)$, and the $b_{\mathrm{abs}, \mathrm{BrC}}$ estimate used in this study and detailed in the steps below represented a lower bound among the differing assumptions (Sect. S4).

For each point in time, $b_{\mathrm{abs}, \mathrm{BrC}}(370)$ was estimated by the following steps: (1) $b_{\mathrm{abs}, \mathrm{BC}}(700)=b_{\mathrm{abs}}(700)$ and $b_{\mathrm{abs}, \mathrm{BC}}(880)=b_{\mathrm{abs}}(880)$ assuming that $b_{\mathrm{abs}, \mathrm{BrC}}=0$ at red wavelengths (e.g., Andreae and Gelencsér, 2006; Wang et al., 2016); (2) $\stackrel{\circ}{a}_{\text {abs, BC }}(700,880)$ was calculated from Eq. (2) using $b_{\mathrm{abs}, \mathrm{BC}}(700)$ and $b_{\mathrm{abs}, \mathrm{BC}}(880)$; (3) $b_{\mathrm{abs}, \mathrm{BC}}(370)$ was calculated from Eq. (2), using $b_{\mathrm{abs}, \mathrm{BC}}(880)$ and $\stackrel{\circ}{a b s, \mathrm{BC}}(370,880)=\stackrel{\circ}{\mathrm{abs}, \mathrm{BC}}_{(700,880)}$ under the assumption that $\stackrel{\circ}{a}_{\text {abs, BC }}$ was independent of wavelength (e.g., Andreae and Gelencsér, 2006; Moosmüller et al., 2009); and finally (4) $b_{\mathrm{abs}, \mathrm{BrC}}(370)$ was obtained by Eq. (1) using $b_{\mathrm{abs}, \mathrm{BC}}(370)$ and $b_{\mathrm{abs}}(370)$. The value of $b_{\mathrm{abs}, \mathrm{BrC}}$ at $430 \mathrm{~nm}$ was also obtained by the same process. Based on $b_{\mathrm{abs}}(370)$ and $b_{\text {abs }}(430), \stackrel{\circ}{a b s}_{\text {abs }}(370,430)$ was estimated. Hereafter, $b_{\text {abs }}$ and $b_{\mathrm{abs}, \mathrm{BrC}}$ refer to $370 \mathrm{~nm}$, and $\stackrel{\circ}{a}$ abs refers to the range of 370 to $430 \mathrm{~nm}$.

The aethalometer, like other filter-based measurement schemes (e.g., PSAP, TAP, or MAAP), is prone to artifacts. These artifacts may originate from light scattering by the filter media itself, the influence of the filter media on the microphysical properties of the collected particle (e.g., potential change in hygroscopic particle size), and the impact of the multiple scattered photons on the measured optical extinction (e.g., enhanced particle absorption as discussed by Nakayama et al., 2010). While several correction schemes 
have been developed to address these artifacts, the individual schemes do not approach these problems in the same way, which may lead to different results among them (Weingartner et al., 2003; Schmid et al., 2006; Collaud Coen et al., 2010; Rizzo et al., 2011; Ammerlaan et al., 2017). For the present analysis, the correction scheme used was described by Rizzo et al. (2011). The potential impact of the different correction schemes on the analysis interpretation was not examined.

\section{Results and discussion}

\subsection{Contributions of biomass-burning and urban emissions to fine-mode PM}

\subsubsection{Comparison of PM concentration and composition across sites}

A comparison between the T3 site and the upwind sites can provide a first-order estimate of the effects of Manaus urban pollution on $\mathrm{PM}_{1}$ concentration and composition (de Sá et al., 2018). During the dry season of 2014, organic compounds dominated the composition at $\mathrm{T} 3$, contributing $83 \pm 6 \%$ (mean \pm 1 standard deviation) of the non-refractory $\mathrm{PM}_{1}\left(\mathrm{NR}-\mathrm{PM}_{1}\right)$, followed by sulfate $(11 \pm 5 \%)$ (Fig. 1a). Mean NR-PM 1 mass concentrations and relative compositions at T3 and at T0a and T2 are represented in Fig. 1b for comparison. Organic material consistently constituted $80 \%$ to $85 \%$ of NR-PM 1 across all three sites. By comparison, the contribution of organic material to NR-PM 1 typically ranged from $70 \%$ to $80 \%$ during the wet season (de Sá et al., 2018).

The NR-PM 1 mass concentrations across the three sites differed slightly (Fig. 1b, top panel). The mean concentration at the T0a site upwind of Manaus was $10.5 \mu \mathrm{g} \mathrm{m}^{-3}$. The mean concentrations at the $\mathrm{T} 2$ site just downwind of Manaus and at the T3 site further downwind were 12.5 and $12.2 \mu \mathrm{g} \mathrm{m}^{-3}$, respectively, representing an increase of about $20 \%$ relative to the upwind site. By comparison, increases of $200 \%$ to $300 \%$ relative to the upwind site were observed during the wet season (de Sá et al., 2018). In absolute mass concentration, however, the difference between upwind and downwind sites of 1 to $2 \mu \mathrm{g} \mathrm{m}^{-3}$ was similar between seasons, suggesting contributions from urban pollution of the same order of magnitude in both seasons. The larger percent increase for the wet season is explained by background concentrations of $1 \mu \mathrm{g} \mathrm{m}^{-3}$, which are an order of magnitude lower compared to the dry season.

The time series of organic mass concentrations across the three sites were well correlated across the 2 months when considering the timescale of a day (Fig. 2a; $0.55<R<$ $0.85)$. Similar behavior was observed for sulfate mass concentrations (Fig. 2b; $0.86<R<0.93$ ). The T0a and T3 sites were separated by $215 \mathrm{~km}$. This result shows that sources and processes of $\mathrm{PM}_{1}$ production at a regional scale were important during the dry season. The data also show that for timescales of an hour the sites were less correlated $(0.70<$ $R<0.80$ for sulfate, and $0.38<R<0.75$ for organic mass concentrations). The large spikes in organic mass concentrations observed at T3 but generally smaller at T2 and absent at T0a could be explained by episodic fires along the Solimões River, especially during nighttime (Fig. 3).

In addition to the widespread and frequent occurrence of fires in the Amazon basin during the dry season (Fig. 3), meteorological conditions may also favor a regional reach of events (Sect. S3). For example, high organic concentrations were observed during the period of 17 to 23 August. During that week, widespread biomass-burning activity in the basin (beyond the scale of Fig. 3), in conjunction with a lack of precipitation events, clear skies, and temperatures of $35^{\circ} \mathrm{C}$ during daytime, allowed for intense photochemical activity and buildup of $\mathrm{PM}_{1}$. There appeared to be an offset in $\mathrm{PM}_{1}$ concentrations by $1 \mathrm{~d}$ between T0a and T3 during that time, which would be consistent with the transport across $215 \mathrm{~km}$ from T0a to T3 for typical easterlies averaging $3 \mathrm{~m} \mathrm{~s}^{-1}$ over the course of a day. In short, a combination of regional-scale biomass-burning activity and meteorological conditions greatly influenced the mass concentration of $\mathrm{PM}_{1}$ at the three sites.

The diel variability of organic and sulfate mass concentrations for the three sites is shown in Fig. 4. Organic mass concentrations were slightly higher at the T2 and T3 sites compared to the T0a site, as expected. The variability was larger at the T2 and T3 sites, especially at night. These two sites are closer to populated areas along the path of the Solimões River and thus are also closer to local biomassburning sources. Activities include burning of crops and trash in houses and farms as well burning of wood in brick kilns (Martin et al., 2016; Cirino et al., 2018). Stagnant air and a shallow boundary layer during the night might explain how variable biomass-burning emissions lead to larger organic mass concentrations and variability at night compared to the day.

The influence of anthropogenic emissions on daytime chemistry is apparent in the diel trends of the sulfate mass concentrations. Sulfate concentrations had low variability throughout the day at T0a, indicating a prevalence of diffuse regional sources that had variations dampened after many hours or days of transport. Possible sources include the atmospheric oxidation of biogenic emissions (DMS, $\mathrm{H}_{2} \mathrm{~S}$ ) from the upwind forest and ocean, as well as long-range transport of fossil fuel combustion emissions from cities in northeastern Brazil and of biomass burning and volcanic emissions from Africa (Andreae et al., 1990; Martin et al., 2010a; Saturno et al., 2018b). Biomass burning can be an important source of sulfate and its precursors (Andreae and Merlet, 2001; Fiedler et al., 2011). For the T2 and T3 sites, sulfate concentrations increased in the morning hours and peaked in the afternoon. The Manaus sulfate source consists of the burning of heavy fuel oil for electricity production, refinery operations, and more diffuse traffic sources, and these emis- 
(a)

(b)
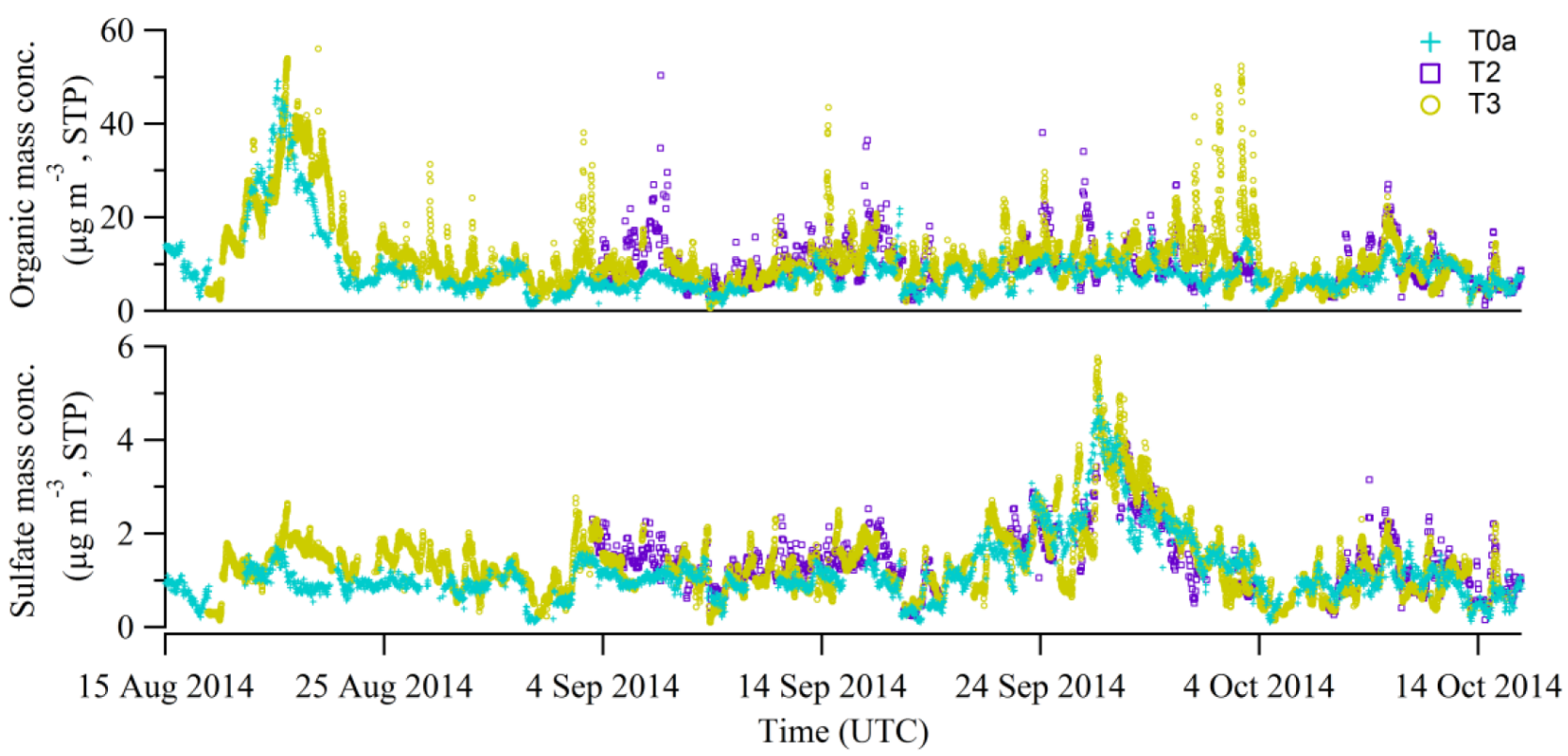

Figure 2. Time series of (a) organic and (b) sulfate mass concentrations at the T0a, T2, and T3 sites. Concentrations were adjusted to standard temperature $(273.15 \mathrm{~K})$ and pressure $\left(10^{5} \mathrm{~Pa}\right)$.

sions reach the $\mathrm{T} 3$ site in the afternoon, when $\mathrm{OH}$ levels are also the highest (de Sá et al., 2017). In addition, biomassburning emissions around $\mathrm{T} 2$ and $\mathrm{T} 3$ might also have contributed to the increase in sulfate concentrations during the afternoons.

\subsubsection{Comparison of PM concentration and composition across clusters for the $\mathrm{T} 3$ site}

A second approach to investigate the changes in concentrations and compositions of the PM with pollution influences employed a combination of PMF and fuzzy $c$-means (FCM) clustering. The PMF analysis was applied to the organic mass spectra to separate the organic $\mathrm{PM}_{1}$ into representative component classes (Sect. "Classification of organic $\mathrm{PM}_{1}$ by positive-matrix factorization"). The FCM clustering algorithm was applied to auxiliary measurements to identify times of urban and biomass-burning influences at the T3 site (Sect. "Cluster analysis"). The results of the FCM analysis were crossed with the findings of the PMF analysis for further insights into pollution-related variability of PM concentration and composition (Sect. "Comparison of $\mathrm{PM}_{1}$ composition among clusters").

\section{Classification of organic $\mathrm{PM}_{1}$ by positive-matrix factorization}

The organic mass spectra recorded by the AMS at the T3 site were analyzed by PMF (Ulbrich et al., 2009). Details and diagnostics of the PMF analysis are presented in the Supplement (Sect. S1). Following the nomenclature used in de
Sá et al. (2018), "mass spectrum" and "mass concentration" refer to the direct AMS measurements, while "factor profile" and "factor loading" are their counterpart mathematical products obtained from the PMF analysis. A six-factor solution was obtained, and the factor profiles, diel trends of the factor loadings, and the time series of the factor loadings and other related measurements are plotted in Fig. 5. The correlations of factor loadings with co-located measurements of gas- and particle-phase species are presented in Fig. 6.

The factors were interpreted considering the mass spectral characteristics of the factor profiles and the correlations between factor loading and mass concentrations of colocated measurements. Three resolved factors interpreted as secondary production and processing closely matched the counterpart profiles of the wet season $(R \geq 0.99$; Table 1) (de Sá et al., 2018). These three factors consisted of a moreoxidized oxygenated factor ("MO-OOA"), a less-oxidized oxygenated factor ("LO-OOA"), and an isoprene epoxydiolsderived factor ("IEPOX-SOA"). Temporal correlations with external tracers and oxidation characteristics were also similar to those of the wet season, corresponding to the first Intensive Operating Period (IOP1) (Fig. 6; Table 1; de Sá et al., 2018). Although a hydrocarbon-like factor ("HOA") was analogous to its counterpart in IOP1 $(R=0.94)$, it also had characteristics of an IOP1 anthropogenic-dominated factor ("ADOA") tied to other urban sources including cooking. The HOA factor of IOP2 therefore represented a mix of the HOA and ADOA factors of IOP1, which could not be separated by PMF in IOP2 due to their lower relative contributions. The interpretation of the HOA, IEPOX-SOA, LOOOA, and MO-OOA factors follows that of IOP1, as pre- 
(a)

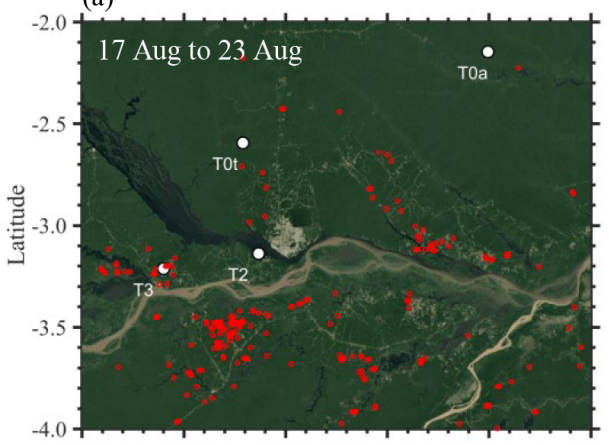

(c)

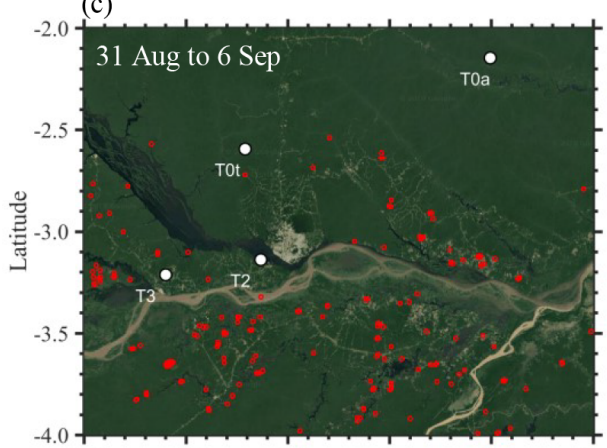

(e)

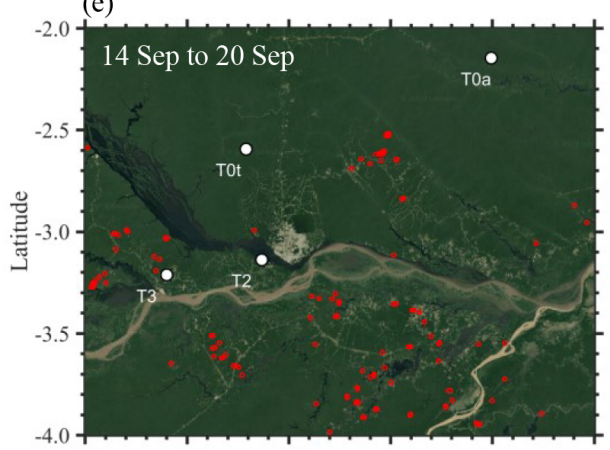

(g)

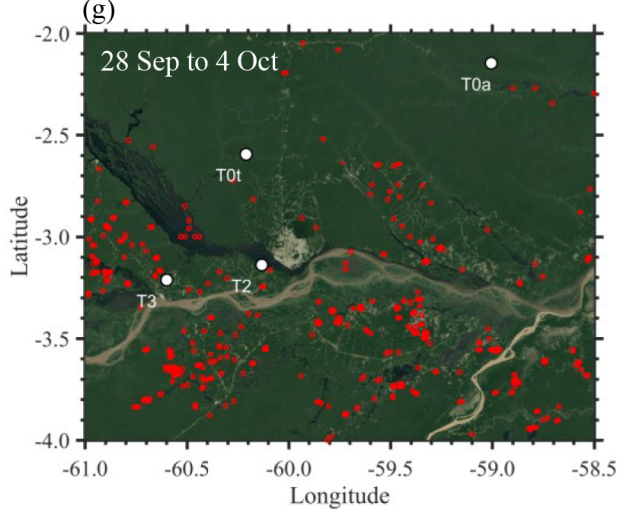

(b)
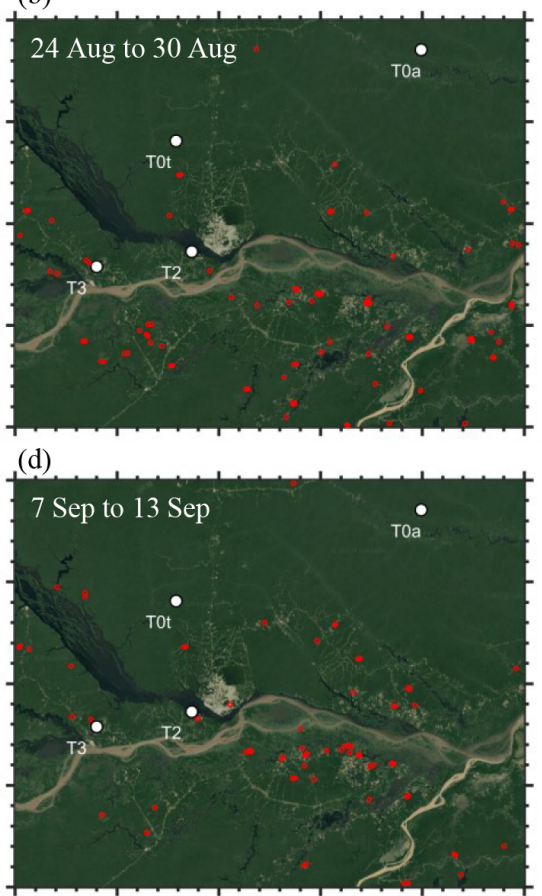

(f)

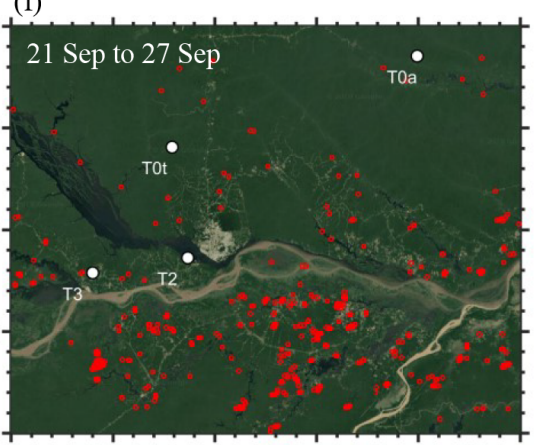

(h)

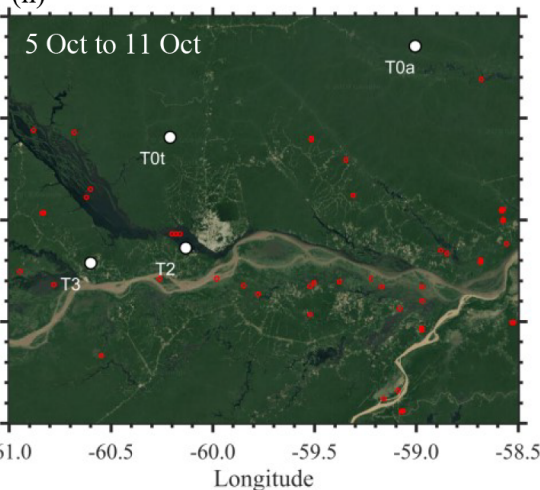

Figure 3. Fire locations in the upwind region of the T3 site for each week of IOP2. Transport times from the fires to the T3 site represent up to $15 \mathrm{~h}$ at the scale of this figure and typical wind speeds. The plotted data were obtained from the fire database of the Brazilian National Institute of Spatial Research (INPE, 2018). Underlying image: Google Maps. 
T0a

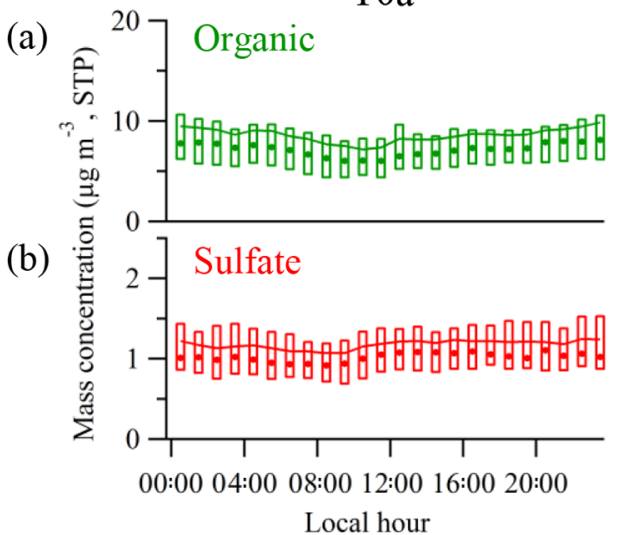

$\mathrm{T} 2$

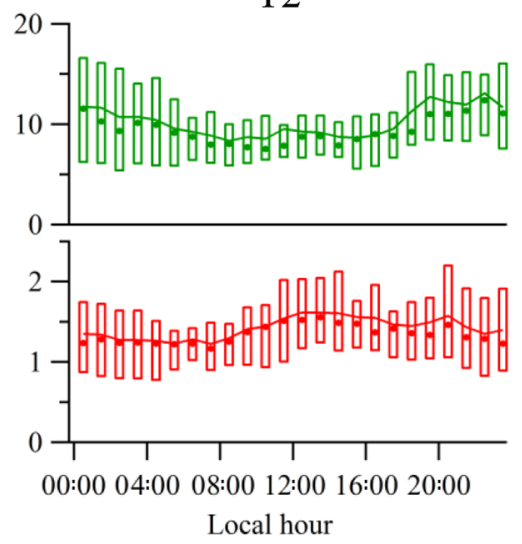

T3

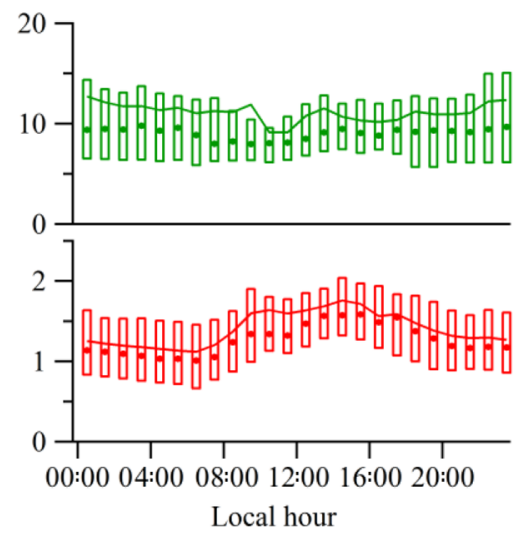

Figure 4. Diel trends of (a) organic and (b) sulfate mass concentrations at the T0a, T2, and T3 sites. Lines represent means, solid markers show medians, and boxes span interquartile ranges. Local time is UTC minus $4 \mathrm{~h}$. Concentrations were adjusted to standard temperature $(273.15 \mathrm{~K})$ and pressure $\left(10^{5} \mathrm{~Pa}\right)$.

sented in de Sá et al. (2018). The following discussion focuses on the two biomass-burning factors of IOP2.

A less-oxidized factor ("LO-BBOA") and a more-oxidized factor ("MO-BBOA") were resolved for IOP2. For IOP1, a single "BBOA" factor was resolved, and it accounted for $9 \%$ of the organic $\mathrm{PM}_{1}$ mass concentration. For IOP2, there were enough differences in mass spectral features and temporal contributions, as well as larger overall contributions of biomass burning, that the PMF analysis identified two different factors. The MO-BBOA and LO-BBOA factors, respectively, accounted for $18 \%$ and $12 \%$ of the mean organic $\mathrm{PM}_{1}$ mass concentration. Therefore, the relative contribution of biomass burning to organic $\mathrm{PM}_{1}$ during the dry season was at least a factor of 3 higher compared to the wet season (a more detailed discussion is presented at the end of this section).

The LO-BBOA and MO-BBOA factor profiles had a distinct peak at nominal $m / z 60\left(\mathrm{C}_{2} \mathrm{H}_{4} \mathrm{O}_{2}^{+}\right)$(Fig. 5a). The fractional intensity $f_{60}$ at $m / z 60$ was larger for LO-BBOA (0.051) than for MO-BBOA (0.013). A peak at $m / z 73$ $\left(\mathrm{C}_{3} \mathrm{H}_{5} \mathrm{O}_{2}^{+}\right)$was also present in both profiles, although its intensity was 3-4 times smaller than that at $m / z 60$. The peaks at $m / z 60$ and 73 are attributed to fragments of levoglucosan and other anhydrous sugars that are produced by the pyrolysis of biomass (Schneider et al., 2006; Cubison et al., 2011). Accordingly, the loadings of both factors correlated with the concentrations of several biomass-burning tracers in the particle phase, including levoglucosan, vanillin, 4-nitrocatechol, syringol, mannosan, syringaldehyde, sinapaldehyde, and long-chain alkanoic acids $\left(\mathrm{C}_{20}, \mathrm{C}_{22}, \mathrm{C}_{24}\right)$ and of tracers in the gas phase (acetonitrile) (Fig. 6). The loadings also correlated with less-specific tracers, including $\mathrm{CO}$ concentration and particle number concentration. The Pearson $R$ correlations were typically higher for the LO-BBOA factor than for the MO-BBOA factor.
The LO-BBOA profile had the greatest ratio of signal intensity of the $\mathrm{C}_{2} \mathrm{H}_{3} \mathrm{O}^{+}$ion $(\mathrm{m} / z 43)$ to that of the $\mathrm{CO}_{2}^{+}$ion $(\mathrm{m} / \mathrm{z} 44)$ compared to all other factors (Fig. 5a). In comparison, the MO-BBOA profile had a high intensity for the $\mathrm{CO}_{2}^{+}$ion and a low intensity for the $\mathrm{C}_{2} \mathrm{H}_{3} \mathrm{O}^{+}$ion. The MOBBOA and LO-BBOA factors had $\mathrm{O}: \mathrm{C}$ ratios of $0.70 \pm 0.07$ and $0.53 \pm 0.04$, respectively. In addition, the LO-BBOA factor loading had higher correlation with the estimated inorganic nitrate concentrations than with the total nitrate concentrations, whereas the MO-BBOA factor did not (Fig. 6; Sect. S1 in the Supplement describes the nitrate estimates). Taken together, these results point to a less-oxidized, highervolatility character of the LO-BBOA factor and a moreoxidized, lower-volatility character of the MO-BBOA factor, both with biomass-burning characteristics (Jimenez et al., 2009; Cubison et al., 2011; Gilardoni et al., 2016; Zhou et al., 2017).

The extent of the biomass-burning influence and atmospheric oxidation on the composition of organic $\mathrm{PM}_{1}$ can be visualized in a scatter plot of $f_{44}$ and $f_{60}$ (Fig. 7a) (Cubison et al., 2011). A background $f_{60}$ value of $0.3 \% \pm 0.06 \%$ (vertical black dashed line) indicates a threshold for negligible or completely oxidized biomass-burning $\mathrm{PM}_{1}$. Points in the lower right of the $f_{44}-f_{60}$ representation usually characterize $\mathrm{PM}_{1}$ tied to recent biomass-burning emissions. For IOP1 (blue markers), all points lie on or close to the background value suggested by Cubison et al. (2011), indicating the absence of a strong influence from biomass burning. During the wet season, biomass burning was limited to local sources or to sources far enough away such as Africa that the $\mathrm{PM}_{1}$ was extensively oxidized by arrival in central Amazonia (de Sá et al., 2018). For IOP2 (red markers), the $f_{60}$ values are greater for most observations, showing that for most times T3 was influenced to some extent by biomass burning (see Sect. "Comparison of PM1 composition among clusters"). This finding is in line with the widespread occur- 
(a)

a)

䓮

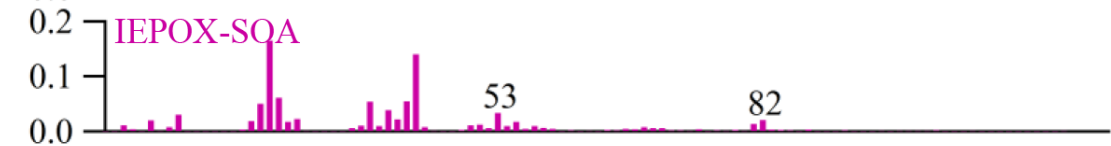

$0.167 \mathrm{MO}-\mathrm{BBOA} \quad 44$
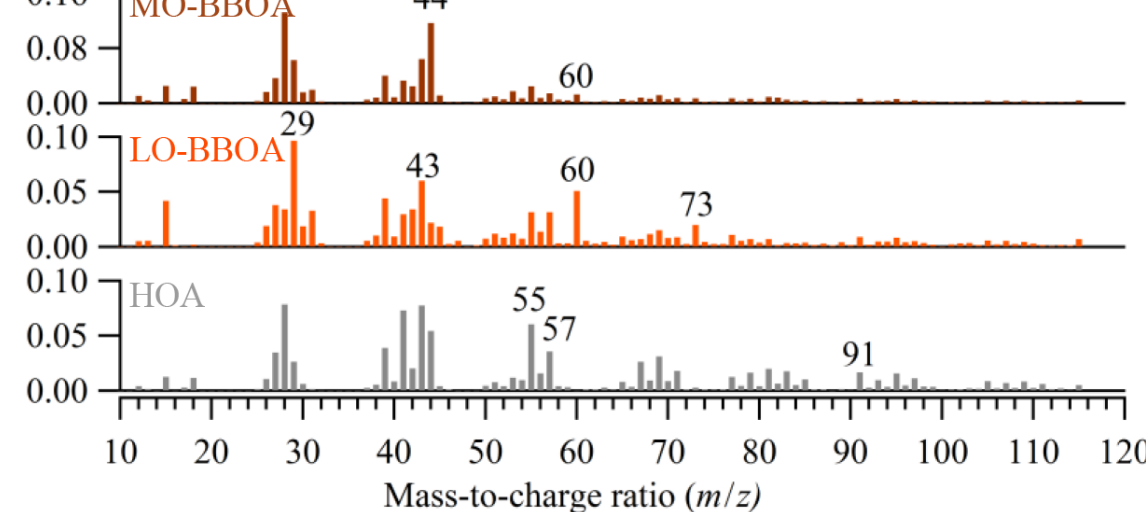

(b)
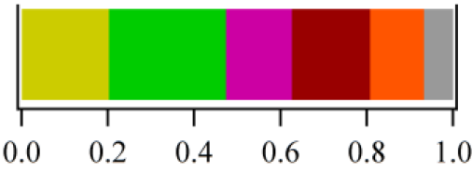

Mean mass fraction

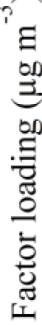
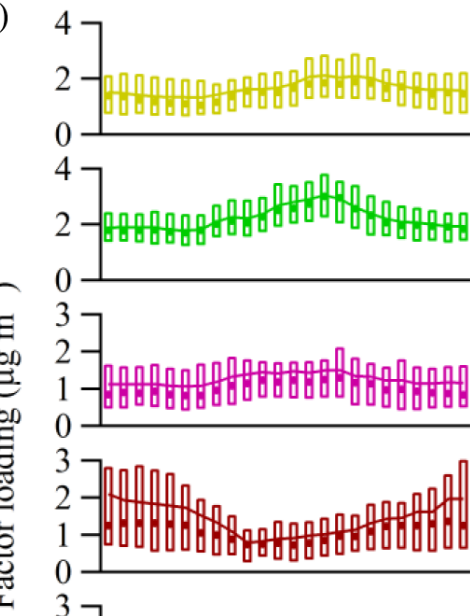

3

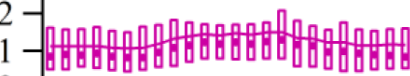

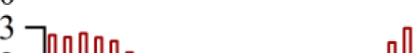

3

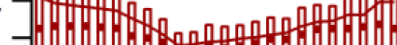

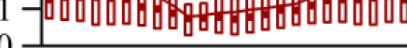

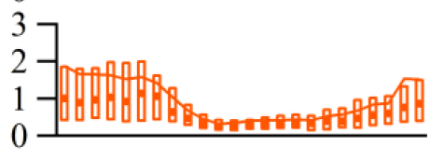

3

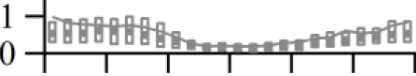

$\begin{array}{lllllll}0 & 4 & 8 & 12 & 16 & 20 & 24\end{array}$

Local hour

(c)

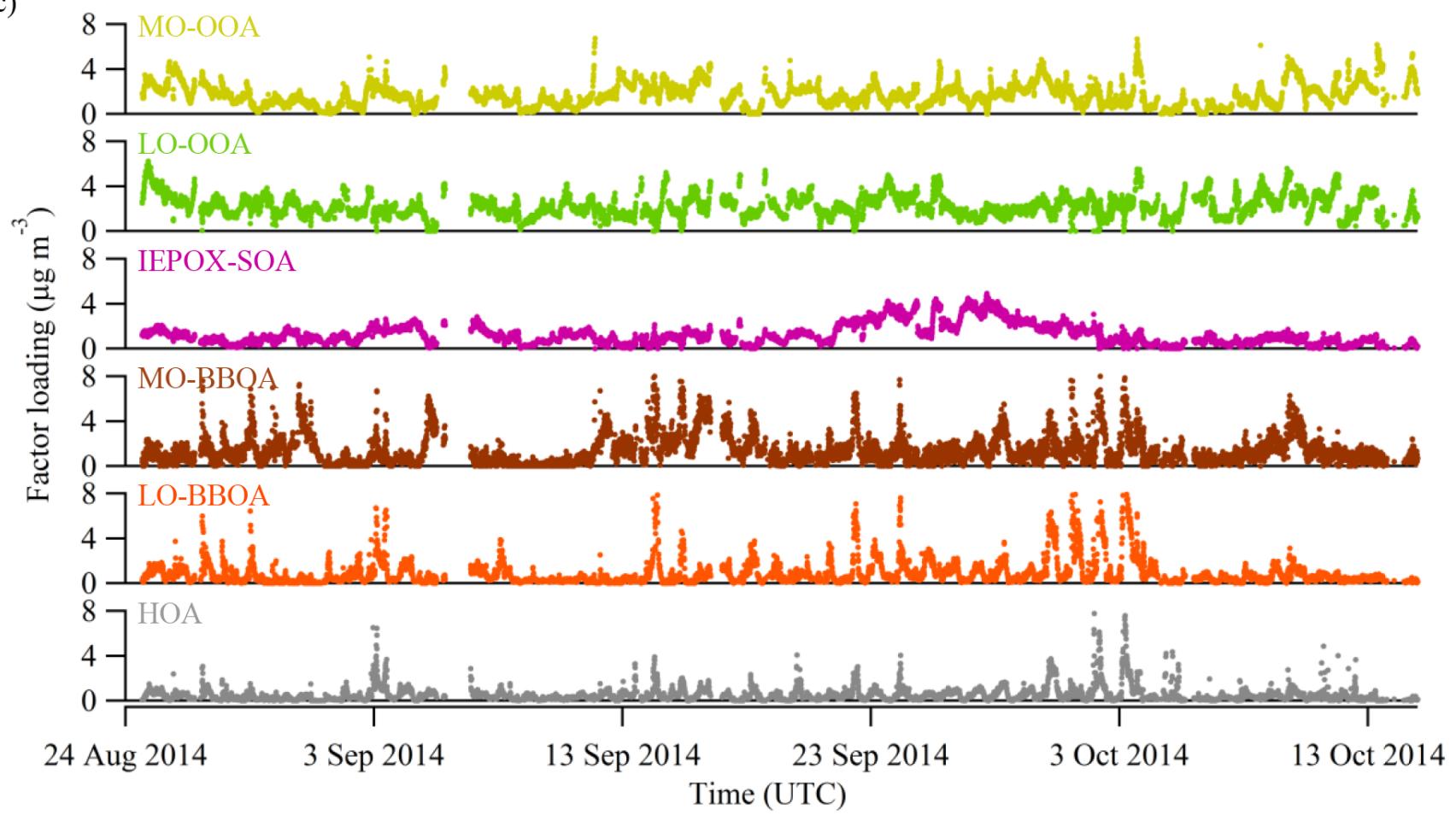

Figure 5. PMF analysis of the time series of AMS organic mass spectra collected at the T3 site. (a) Mass spectral profile of each factor represented at unit mass resolution. The inset shows the mean fractional loading of each factor. The factor profiles are shown in more detail, colored by ion families, in Fig. S5. (b) Diel trends for the loadings of each PMF factor. Local time is UTC minus $4 \mathrm{~h}$. Lines represent means, solid markers show medians, and boxes span interquartile ranges. (c) Time series of the factor loadings. 


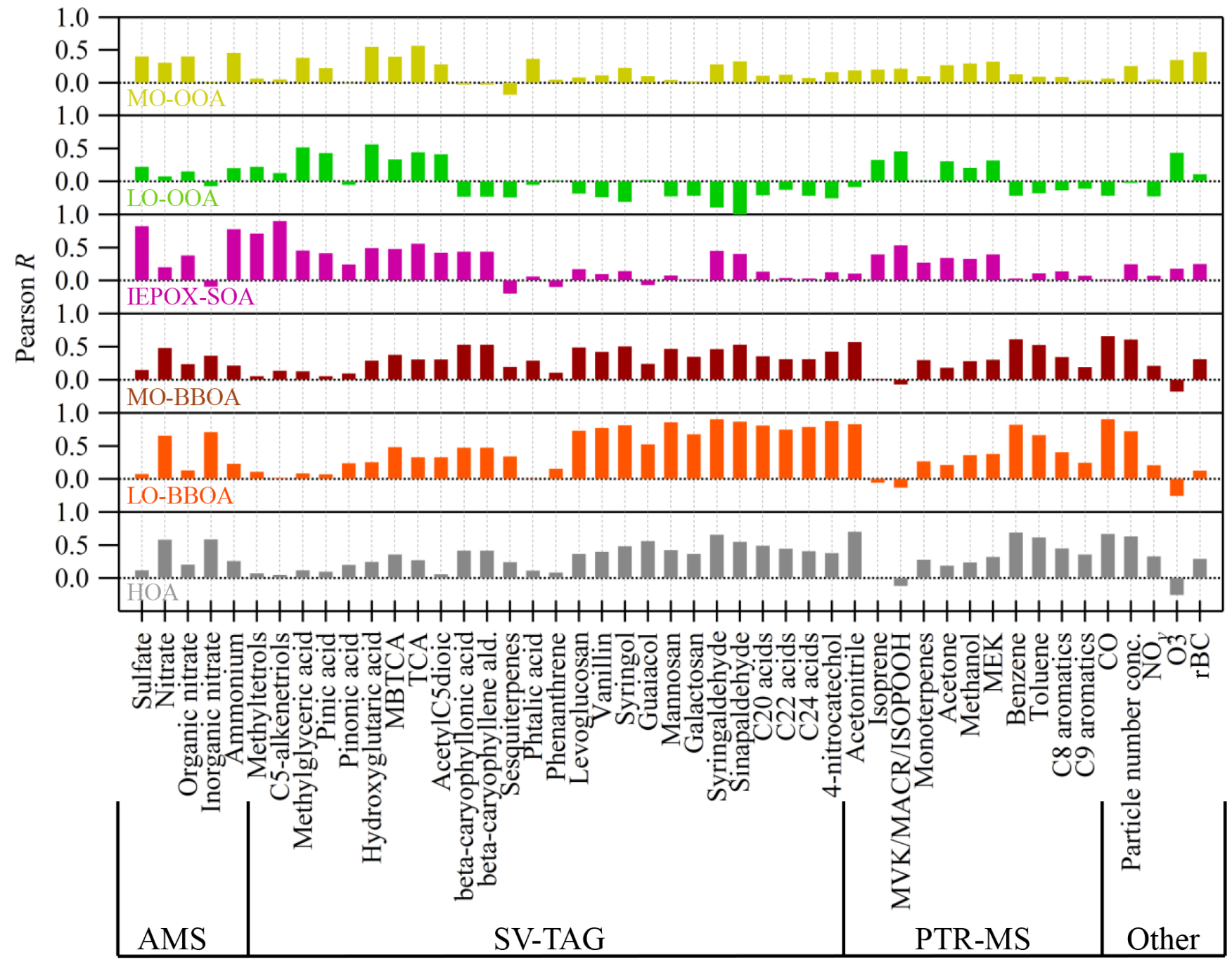

Figure 6. Pearson $R$ correlations between the loading of each PMF factor and concentrations of selected measurements at the T3 site. Abbreviations include tricarballylic acid (TCA), methyl-butyl-tricarboxylic acid (MBTCA), methyl vinyl ketone (MVK), methacrolein (MACR), isoprene hydroxyhydroperoxides (ISOPOOH), and rBC. SV-TAG measurements refer to particle-phase concentrations, except for sesquiterpenes which refer to total concentrations and mostly occurred in the gas phase. The $\mathrm{C}_{8}$ and $\mathrm{C}_{9}$ aromatics include the xylene and trimethylbenzene isomers, respectively. The $\mathrm{C}_{20}, \mathrm{C}_{22}$, and $\mathrm{C}_{24}$ acids include eicosanoic, docosanoic, and tetracosanoic acids, respectively.

rence of fires during the dry season (Fig. 3). As suggested by the robust trend in Fig. 7a, the $f_{44}$ value increases and the $f_{60}$ value decreases from the bottom right to the upper left as the organic $\mathrm{PM}_{1}$ emitted by biomass burning is oxidized in the atmosphere. The $f_{60}$ and $f_{44}$ values of the LO-BBOA and MO-BBOA profiles, plotted as diamonds, lie on the linear trend.

The LO-BBOA factor of high $f_{60} / f_{44}$ and low $\mathrm{O}$ : $\mathrm{C}$ thus appears associated with primary $\mathrm{PM}_{1}$ emitted by biomass burning. The MO-BBOA factor, characterized by low $f_{60} / f_{44}$ and high $\mathrm{O}: \mathrm{C}$, may represent a combination of primary $\mathrm{PM}_{1}$ of higher oxygen content as well as secondary $\mathrm{PM}_{1}$ tied to biomass burning in its early stages of atmospheric processing (Cubison et al., 2011; Gilardoni et al., 2016). These secondary pathways could include (i) the heterogeneous oxidation of primary $\mathrm{PM}_{1}$, such as that represented by the LO-BBOA factor, and (ii) the oxidation of gas-phase biomass-burning emissions or of species evaporated from primary $\mathrm{PM}_{1}$, followed by the condensation of the gas-phase products onto the $\mathrm{PM}_{1}$.

The LO-BBOA and MO-BBOA factor loadings had greater magnitude and variability at night compared to during the day (Fig. 5b). Their summed loading, represented as "BBOA ${ }_{\mathrm{T}}$ ", accounted for $40 \%$ and $13 \%$ of the organic $\mathrm{PM}_{1}$ during night and day, respectively. Overall, they accounted for $30 \%$ of the organic $\mathrm{PM}_{1}$. This result reflects the importance of fire activity during all times of day and during the entirety of IOP2 (Fig. 3). The surface concentrations were 
Table 1. Characteristics of the PMF factor profiles. Listed are $f_{44}$ and $f_{60}$, corresponding to the organic signal fraction at $m / z 44$ and 60 , respectively, as well as the oxygen-to-carbon $(\mathrm{O}: \mathrm{C})$ and hydrogen-to-carbon $(\mathrm{H}: \mathrm{C})$ ratios. Values and uncertainties were calculated by running the PMF analysis in "bootstrap mode" (Ulbrich et al., 2009). The Pearson $R$ correlations between the factor profiles of IOP2 and their counterparts in IOP1 are also listed (i.e., dry season compared to wet season). "n/a" means "not applicable". Elemental ratios were calibrated by the "improved-ambient" method, which has an estimated uncertainty of $12 \%$ for O : C and 4\% for $\mathrm{H}: \mathrm{C}$ (Canagaratna et al., 2015).

\begin{tabular}{lrrrrr}
\hline PMF factor & $f_{44}$ & $f_{60}$ & $\mathrm{O}: \mathrm{C}$ & $\mathrm{H}: \mathrm{C}$ & $\begin{array}{r}\text { Pearson } R \\
\text { against IOP1 } \\
\text { counterpart }\end{array}$ \\
\hline MO-OOA & $0.24 \pm 0.01$ & $<0.001$ & $1.20 \pm 0.10$ & $1.25 \pm 0.08$ & 1.00 \\
LO-OOA & $0.15 \pm 0.01$ & $0.001 \pm 0.001$ & $0.86 \pm 0.08$ & $1.51 \pm 0.06$ & 0.99 \\
IEPOX-SOA & $0.14 \pm 0.01$ & $<0.001$ & $0.74 \pm 0.02$ & $1.51 \pm 0.01$ & 0.99 \\
MO-BBOA & $0.13 \pm 0.01$ & $0.011 \pm 0.003$ & $0.70 \pm 0.07$ & $1.59 \pm 0.11$ & $\mathrm{n} / \mathrm{a}$ \\
LO-BBOA & $0.02 \pm 0.01$ & $0.05 \pm 0.01$ & $0.53 \pm 0.04$ & $1.79 \pm 0.06$ & $\mathrm{n} / \mathrm{a}$ \\
HOA & $0.05 \pm 0.01$ & $0.001 \pm 0.001$ & $0.22 \pm 0.03$ & $1.82 \pm 0.03$ & 0.94 \\
\hline
\end{tabular}

lower during the day because biomass-burning emissions are diluted with the development of the planetary boundary layer (PBL) and with the increased wind speeds as compared to the stagnant air and shallower PBL at night. The occurrence of significant dilution indicates that the emission sources were at least in part within a day of transport, meaning a distance on the order of a few hundred kilometers. The fractional contribution of the MO-BBOA factor to $\mathrm{BBOA}_{\mathrm{T}}$ shifted from 0.7 to 0.5 from day to night, while that of LO-BBOA correspondingly shifted from 0.3 to 0.5 (Fig. 7b). This result is consistent with an additional secondary contribution to the MOBBOA loading during daytime, including from LO-BBOA oxidation and possibly tied to photochemical processing, on top of a primary source from biomass burning.

Although the footprint of biomass burning is geographically more widespread throughout the basin compared to the urban footprint of nearby Manaus, fire incidence and large-scale emissions have historically concentrated in a region known as the arc of deforestation along the southern rim of the forest (Fuzzi et al., 2007; Artaxo et al., 2013). Several campaigns have focused on the effects of biomass burning during the dry season at locations that are highly affected by fires, usually in the states of Rondônia or Mato Grosso, within the arc of deforestation (SCAR-B, Kaufman et al., 1998; LBA-SMOCC, Fuzzi et al., 2007; LBAEUSTACH, Andreae et al., 2002; TROFEE, Yokelson et al., 2007; SAMBBA, Morgan et al., 2013). At a ground site in Porto Velho, Rondônia, a PMF analysis of ACSM data showed that $70 \%$ of the organic $\mathrm{PM}_{1}$ could be attributed to biomass burning (Brito et al., 2014). Compared to the present study, in which at least $30 \%$ of the organic $\mathrm{PM}_{1}$ can be directly attributed to biomass burning, the contributions of fires to $\mathrm{PM}_{1}$ in the arc of deforestation region are considerably larger.

The combined contribution of $30 \%$ by MO-BBOA and LO-BBOA at T3 represents a lower bound of biomassburning influence because more-oxidized material from biomass burning could be accounted for by the MO-OOA factor. In the limiting assumption that all MO-OOA loadings originated from BBOA loadings, an upper limit of $50 \%$ can be established for the mean contribution of biomass burning to organic $\mathrm{PM}_{1}$ concentrations at $\mathrm{T} 3$. Considering that all organic $\mathrm{PM}_{1}$ components have been observed to age into MOOOA at similar rates (Jimenez et al., 2009), a more likely estimate of $38 \%$ can be derived by assuming that all factors contribute to MO-OOA proportionally to their ambient concentrations.

An important implication of these results, together with those of the wet season, is that although $\mathrm{PM}_{1}$ concentrations increase on average by a factor of 8.5 between seasons, not all of the increase is due to biomass burning, which has been a common assumption in previous studies (Artaxo et al., 1994, 2002, 2013; Holben et al., 1996; Echalar et al., 1998; Maenhaut et al., 1999; Andreae et al., 2002; Mace et al., 2003; Martin et al., 2010b; Rizzo et al., 2013; Brito et al., 2014; Pöhlker et al., 2016). In absolute mass concentrations, the contribution from biomass burning increased from $0.12 \mu \mathrm{g} \mathrm{m}^{-3}$ in the wet season to $3.4 \mu \mathrm{g} \mathrm{m}^{-3}$ in the dry season, which represents a 30 -fold increase. This result corresponds to a change in percentage contribution to organic $\mathrm{PM}_{1}$ from $9 \%$ to $30 \%$ (not counting with the mass presumably present in MO-OOA). Nevertheless, the contribution from secondary biogenic sources (and their anthropogenically affected processes), as represented by the LO-OOA and IEPOX-SOA factors, also increased by around 8-fold from 0.6 to $4.8 \mu \mathrm{g} \mathrm{m}^{-3}$. In absolute terms, this mass increase (of $4.2 \mu \mathrm{g} \mathrm{m}^{-3}$ ) is comparable to the one associated with biomass burning $\left(3.3 \mu \mathrm{g} \mathrm{m}^{-3}\right)$. Because the 8 -fold mass increase of LO-OOA and IEPOX-SOA was similar to the 8.5 -fold increase in total organic $\mathrm{PM}_{1}$, these factors show a similar mass percentage contribution of $42 \%$ to organic $\mathrm{PM}_{1}$ for both seasons. The MO-OOA factor loadings increased by 6 -fold from 0.4 to $2.3 \mu \mathrm{g} \mathrm{m}^{-3}$. Because this relative increase was smaller than that of the total organic $\mathrm{PM}_{1}$, the MO-OOA factor had a 
(a)

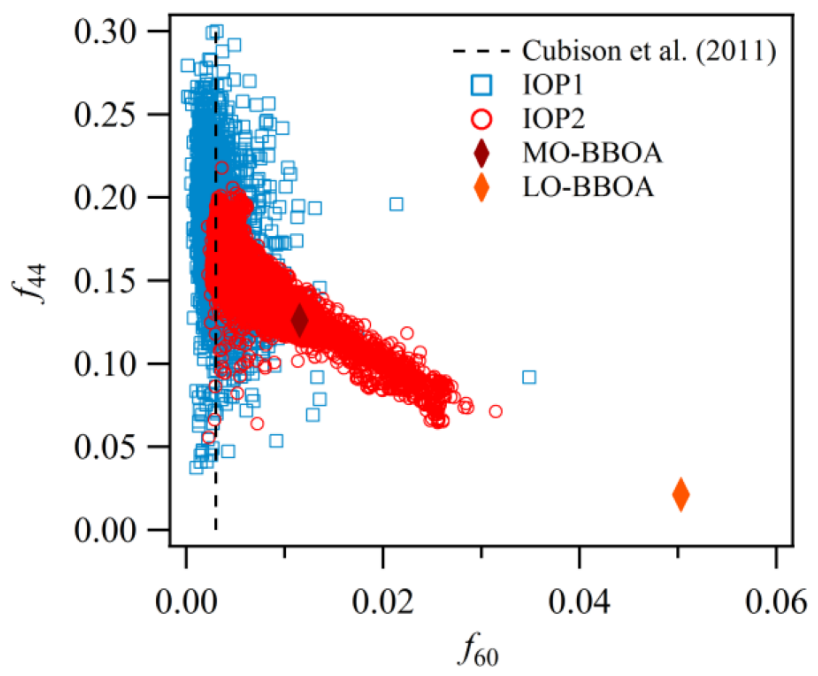

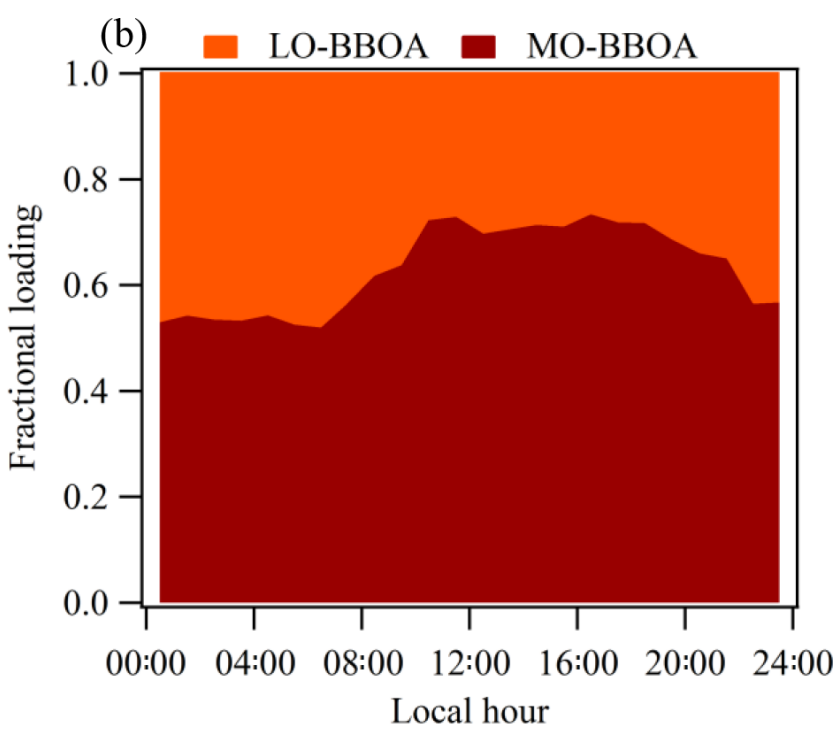

Figure 7. Analysis of the organic $\mathrm{PM}_{1}$ sampled at the $\mathrm{T} 3$ site in relation to biomass burning. (a) Scatter plot of the AMS signal fraction at $m / z 44\left(f_{44}\right)$ against that at $m / z 60\left(f_{60}\right)$. Red circles represent measurements during the dry season (IOP2), and blue squares represent measurements at the same site during the wet season (IOP1) (de Sá et al., 2018). Diamonds represent the MO-BBOA and LO-BBOA factors of IOP2. The dashed line represents a reference for negligible influence by biomass burning based on several field studies (Cubison et al., 2011). (b) Diel trends of the fractional loadings of the MO-BBOA and LO-BBOA factors relative to their sum BBOAT. Local time is UTC minus $4 \mathrm{~h}$.

decrease from $30 \%$ to $20 \%$ of contribution to organic $\mathrm{PM}_{1}$. The contribution from urban sources, as represented by the HOA and ADOA factors, increased by 3 -fold between seasons, from 0.24 to $0.76 \mu \mathrm{g} \mathrm{m} \mathrm{m}^{-3}$, representing a decrease in mass percentage contribution from $18 \%$ to $7 \%$.

Therefore, reasons other than increased biomass burning in the dry season must have played a role in increasing organic $\mathrm{PM}_{1}$ concentrations. Importantly, the mass concentrations of sulfate and ammonium also increased by 6 -fold between seasons (Fig. S10), indicating that atmospheric physical processes governing particle mass concentrations possibly played an important role. In this context, reduced wet deposition due to reduced convection in the dry season may be one important contributor to the organic $\mathrm{PM}_{1}$ increases (Machado et al., 2004; Nunes et al., 2016; Chakraborty et al., 2018). Another aspect is that biogenic NMVOC (BVOC) emissions are typically higher in the dry season (YáñezSerrano et al., 2015; Alves et al., 2016), which might partly explain the increases in LO-OOA, IEPOX-SOA, and MOOOA factors. In addition, the directly measured biogenic (total) secondary organic $\mathrm{PM}_{1}$ formation potential of ambient air increased by a factor of 2.4 (1.7) between seasons (Palm et al., 2018). Increased organic mass available for partitioning may account for another factor of 2 (Palm et al., 2018). As a consequence of increased $\mathrm{PM}_{1}$ mass concentrations, the lifetime of semi-volatile gases may also be increased, since lifetime against dry deposition is much larger for particles than for gases (Knote et al., 2015). Increased oxidant levels during the dry season could also be a contributing factor
(Rummel et al., 2007; Artaxo et al., 2013; Andreae et al., 2015; Yáñez-Serrano et al., 2015; Fuentes et al., 2016).

\section{Cluster analysis}

The time series of the afternoon concentrations of particle number, $\mathrm{NO}_{y}$, ozone, $\mathrm{rBC}$, carbon monoxide, and sulfate were analyzed by fuzzy $c$-means clustering at the time resolution of the AMS measurements. The algorithm attributed degrees of cluster membership to each data point based on similarity in the sets of input concentrations (Sect. S2). The scope was restricted to data sets for which $10 \mathrm{~h}$ air-mass back-trajectories did not intersect precipitation. The scope also excluded data sets tied to the lowest $10 \%$ of solar irradiance averaged over the previous $4 \mathrm{~h}$ at T3 (Sect. S2 in the Supplement). This approach aimed to capture fair-weather conditions and thereby minimize the role of otherwise confounding processes that influence mass concentrations, such as boundary layer dynamics and wet deposition.

Three clusters, labeled "baseline," "event," and "urban," were identified based on a combination of minimization of the FCM objective function and an assessment of meaningfulness of the resolved set of clusters. Illustrative examples of the obtained degrees of membership ( 0 to 1$)$ are plotted in Fig. 8a for several time windows. The concentrations of the input and additional species are plotted in Fig. $8 \mathrm{~b}$ and c. The PMF results of Sect. "Classification of organic PM by positive-matrix factorization" are plotted for comparison in Fig. 8d. Air-mass back-trajectories are plotted in Fig. 9 for 
time windows predominantly associated with only one cluster.

All three clusters reflected, albeit to different degrees, some influence of biomass burning. For the wet season, de Sá et al. (2018) identified clusters representing background conditions, which were characterized by low concentrations of particle number, $\mathrm{NO}_{y}$, and $\mathrm{O}_{3}$. For the dry season, no similar cluster was identified. As shown in Fig. 3, there were fires in the region at all times (cf. Martin et al., 2017).

The baseline cluster had the lowest concentrations of pollutant indicators, representing influences of far-field biomass burning on top of natural (i.e., biogenic) emissions and atmospheric processing. The cluster centroid corresponded to $1.3 \mathrm{ppb} \mathrm{NO}_{y}, 30 \mathrm{ppb}$ ozone, and 2000 particles $\mathrm{cm}^{-3}$ (Table S1 in the Supplement). Results for 27 August, $28 \mathrm{Au}-$ gust, and 9 September illustrate these lower concentrations compared to the other days (Fig. 8). The back-trajectories associated with the baseline cluster did not intersect the urban area of Manaus, especially the southern region of presumed higher emissions (Fig. 9a; de Sá et al., 2018).

The event cluster referred to conditions of increased influence from biomass burning and long-range transport of volcanic emissions from Africa. The cluster corresponded to a $10 \mathrm{~d}$ period from 22 September to 1 October in which biomass burning intensified in the surroundings of T3 as well as more broadly in the Amazon basin (Fig. 3f and g). Coincidentally, plumes carrying emissions from the NyamuragiraNyiragongo volcanoes in Africa were also observed to reach central Amazonia during that time period, as demonstrated by Saturno et al. (2018b). This cluster was characterized by higher concentrations of all species in relation to the baseline cluster (Table S1). In particular, the sulfate concentrations $\left(2.3 \mu \mathrm{g} \mathrm{m}^{-3}\right.$ at the centroid) were the highest among the three clusters. Results for 23, 27, and 28 September illustrate these findings for $\mathrm{T} 3$, with sulfate concentrations reaching $4 \mu \mathrm{g} \mathrm{m}^{-3}$ (Fig. 8). This trend in sulfate concentrations was consistent across all three sites (Fig. 2). The back-trajectories associated with the event cluster were variable, passing to the north, directly over, and to the south of Manaus, although always with an east component (Fig. 9b). The long-range transport and increased regional fire count during the event period thus appeared more important in defining this cluster than did the directions of the back-trajectories in a smaller scale, making Manaus emissions of secondary importance.

The urban cluster had the highest centroid concentrations of $\mathrm{NO}_{y}(2.6 \mathrm{ppb})$, ozone (56.4 ppb), and particle number $\left(4600 \mathrm{~cm}^{-3}\right)$ among the three clusters (Table S1). It represented conditions for which both biomass-burning and urban emissions were relevant, and these emissions may have interacted before reaching the T3 site. The results for 24 August, 11 September, 14 September, and 8 October illustrate the high pollutant concentrations (Fig. 8). The back-trajectories associated with the urban cluster consistently passed over Manaus and, more specifically, over the southern region where human activities were more concentrated (Fig. 9c).

\section{Comparison of $\mathrm{PM}_{1}$ composition among clusters}

Species mass concentrations and PMF factor loadings associated with the cluster centroids were determined (Sect. S2). The resulting organic, sulfate, ammonium, nitrate, and chloride mass concentrations associated with each cluster are represented in Fig. 10a. The PMF factor loadings associated with each cluster are likewise represented in Fig. 10b.

The summed NR-PM 1 mass concentrations for the centroids of the event and urban clusters were both $12.3 \mu \mathrm{g} \mathrm{m}^{-3}$. This concentration was $33 \%$ higher than that representing the baseline cluster $\left(9.2 \mu \mathrm{g} \mathrm{m}^{-3}\right)$. This result thus agrees with that based on direct comparison of $\mathrm{PM}_{1}$ mass concentrations between the T3 and the T0a sites (Sect. 3.1.1). Therefore, the overall effect of Manaus pollution was to add 1 to $3 \mu \mathrm{g} \mathrm{m}^{-3}$ on top of the upwind concentrations. Increases in the organic mass concentration dominated the overall increase in $\mathrm{PM}_{1}$ mass concentration because organic species dominated the composition for all three clusters. The increases in organic mass concentration for the event and urban clusters relative to the baseline cluster were $26 \%$ and $33 \%$, respectively (Fig. 10a).

Sulfate concentrations also increased relative to the baseline cluster, corresponding to $65 \%$ for the event cluster and $31 \%$ for the urban cluster. This result indicates that strong biomass-burning emissions reaching areas downwind of Manaus as well as long-range transport of volcanic emissions from as far away as Africa may increase sulfate concentrations in those areas beyond the sulfate values driven by the anthropogenic activities in the city. In other words, there were several other in-basin as well as out-of-basin sources of sulfate besides Manaus that could sustain relatively high sulfate concentrations (Chen et al., 2009; de Sá et al., 2017; Saturno et al., 2018b).

The relationship between clusters and PMF factors is represented in Fig. 10b. All three clusters were associated with an organic $\mathrm{PM}_{1}$ composition dominated by secondary production. The baseline cluster was largely dominated by the LO-OOA factor $(40 \%)$. By comparison, the event cluster had significant increases in the LO-BBOA, MO-BBOA, and IEPOX-SOA factor loadings. The increase in LO-BBOA and MO-BBOA loadings $(40 \%)$ can be associated with the increased contributions of primary and secondary particle components from biomass burning, respectively. The LO-BBOA factor had the highest loading $\left(0.5 \mu \mathrm{g} \mathrm{m}^{-3}\right)$ for the event cluster, consistent with the high incidence of fires during the period represented by this cluster. The increase of $65 \%$ in IEPOX-SOA loading can be explained by the disproportionally higher increase of $65 \%$ in the sulfate concentration (which favors higher IEPOX-SOA loadings), accompanied by the relatively moderate increase of $34 \%$ in $\mathrm{NO}_{y}$ concentration (which suppresses IEPOX-SOA loadings), leading to a net increase in IEPOX-SOA loadings (Table S1; de Sá et al., 2017). 
(a)

(b)

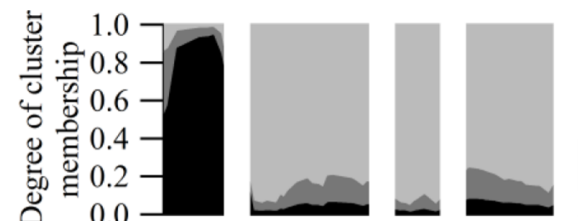

(d)

(c)
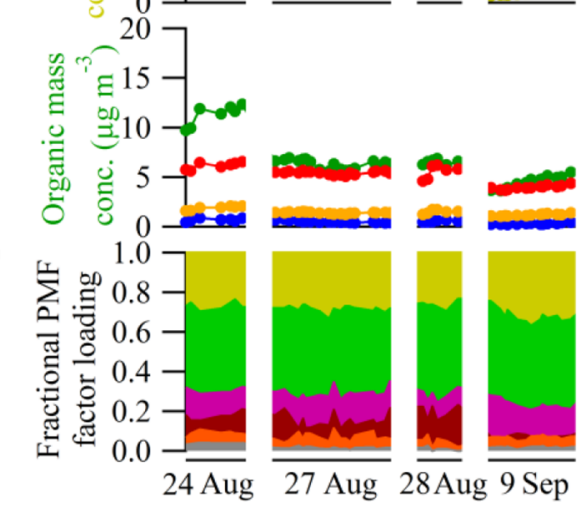

0
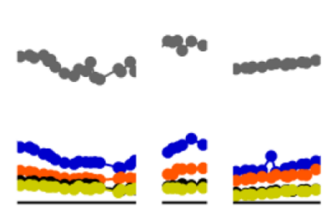
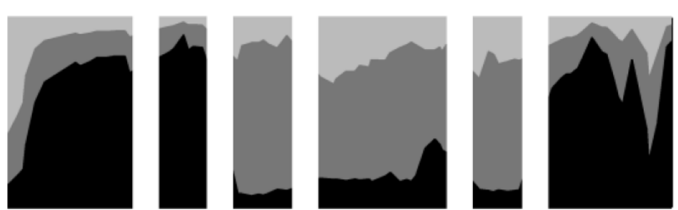

Baseline
Event
- Urban
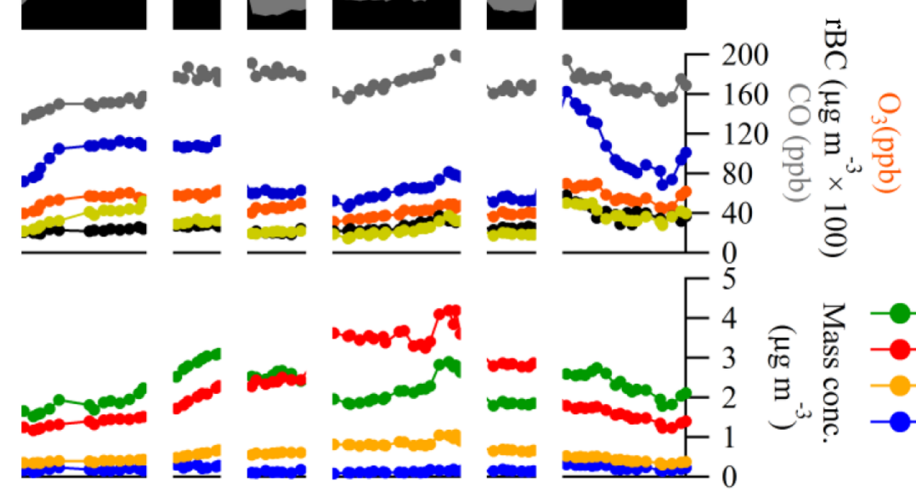

$3-0$ - Organic

言

$\Xi$ \& $\rightarrow$ Ammonium

¿山 $\rightarrow$ Nitrate

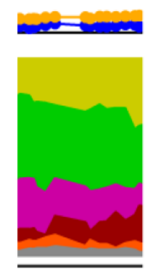

11 Sep

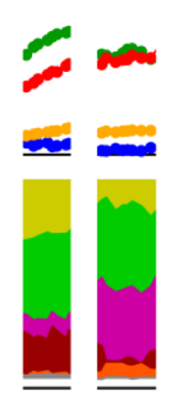

$14 \mathrm{Sep} 23 \mathrm{Sep}$

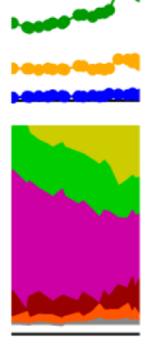

$27 \mathrm{Sep} 28$

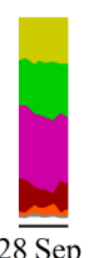

$28 \mathrm{Sep}$

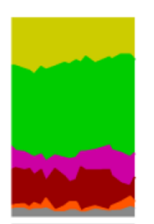

8 Oct

Figure 8. Results of the cluster analysis by FCM clustering for afternoon periods (12:00 to 16:00 LT) presented by several case studies. The shown case studies represent $30 \%$ of the FCM results. (a) Degree of membership in each of the three clusters. The sum of degrees of membership across all clusters is unity. (b) Pollution indicators: concentrations of $\mathrm{NO}_{y}, \mathrm{O}_{3}, \mathrm{CO}, \mathrm{rBC}$, and particle number count are plotted. (c) $\mathrm{PM}_{1}$ mass concentrations for organic, sulfate, nitrate, and ammonium species. (d) Fractional contribution of each factor to the $\mathrm{PM}_{1}$ organic mass concentration.

The composition of the organic $\mathrm{PM}_{1}$ associated with the urban cluster differed from that of the two other clusters, as indicated by the factor contributions (Fig. 10). Compared to the baseline cluster, the loadings of all factors except IEPOXSOA increased. An increase in HOA loading is consistent with emissions in the city, including from vehicles and power plants. An increase in the loadings associated with secondary processes, as represented by the MO-OOA, LO-OOA, and MO-BBOA factors, can be explained by the accelerated oxidation cycle in the plume. In brief, an increase in the concentrations of both precursors and oxidants provided by urban emissions accelerates the production of secondary $\mathrm{PM}_{1}$ and thereby increases the $\mathrm{PM}_{1}$ concentrations downwind of the city (Martin et al., 2017; de Sá et al., 2018).

The similarity in IEPOX-SOA factor loading for the baseline and the urban clusters may be explained by the following aspects. First, the lifetime of IEPOX-derived PM in the boundary layer is thought to be around 2 weeks (Hu et al., 2016). Therefore, a substantial fraction of this component observed at T3 will be formed upwind of the Manaus plume. Second, favored conditions for IEPOX production and uptake are low $\mathrm{NO}$ concentrations (i.e., $\mathrm{HO}_{2}$-dominant pathway for the ISOPOO radical) and high sulfate concentrations (de Sá et al., 2017). Sulfate concentrations increased by $31 \%$, and $\mathrm{NO}_{y}$ concentrations, used as an indicator for exposure of the air mass to NO concentrations, increased by $100 \%$ for the urban compared to the baseline cluster. These two changes work against one another with respect to IEPOX production and uptake. For the wet season, de Sá et al. (2017) reported that the IEPOX-SOA factor loading was more sensitive to changes in $\mathrm{NO}_{y}$ concentration for $1 \mathrm{ppb}$ and less. By comparison, $\mathrm{NO}_{y}$ concentrations in the dry season were consistently greater than this value. Due to this lower sensitivity, large increases in $\mathrm{NO}_{y}$ may not be tied to large decreases in IEPOXSOA factor loading in the dry season. In sum, the opposite roles of sulfate and $\mathrm{NO}_{y}$ concentrations can explain the net zero change in IEPOX-SOA factor loadings between baseline and urban clusters. Because all of the loadings for other factors increased, the fractional loading of IEPOX-SOA decreased from $26 \%$ to $15 \%$.

\subsection{Contributions of biomass-burning and urban emissions to brown carbon}

\subsubsection{Brown carbon light absorption}

The diel trends of $b_{\mathrm{abs}}, b_{\mathrm{abs}, \mathrm{BrC}}, b_{\mathrm{abs}, \mathrm{BrC}} / b_{\mathrm{abs}}$, and $\stackrel{\circ}{\mathrm{abs}}_{\text {are }}$ shown in Fig. 11. Both $b_{\mathrm{abs}}$ and $b_{\mathrm{abs}, \mathrm{BrC}}$ were larger and had greater variability at night compared to day. The variability 

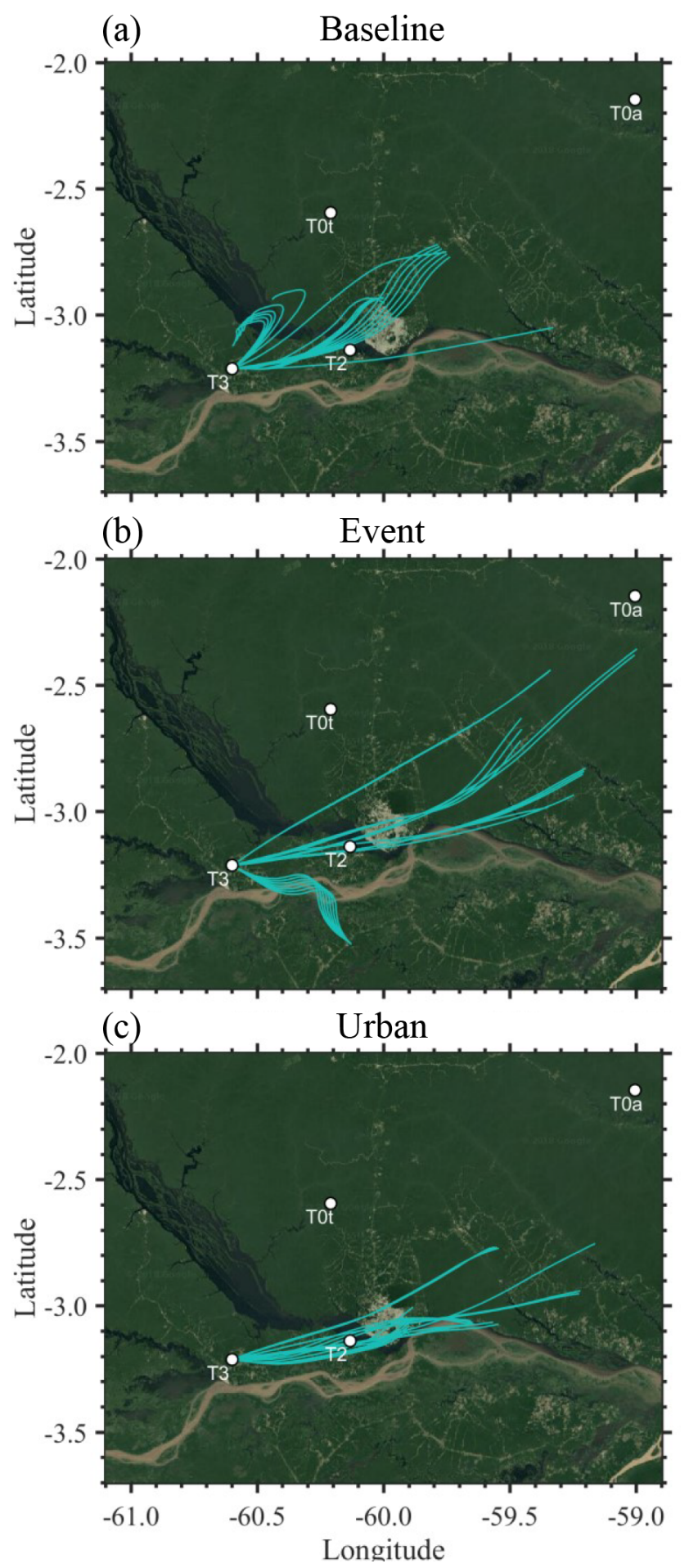

Figure 9. Air-mass back-trajectories associated with the three clusters of the FCM analysis. Trajectories were calculated using HYSPLIT4 in steps of $12 \mathrm{~min}$ and are shown for $10 \mathrm{~h}$ (Draxler and Hess, 1998). A total of 20 trajectories are plotted for each cluster, corresponding to the times of highest degree of membership to that cluster.

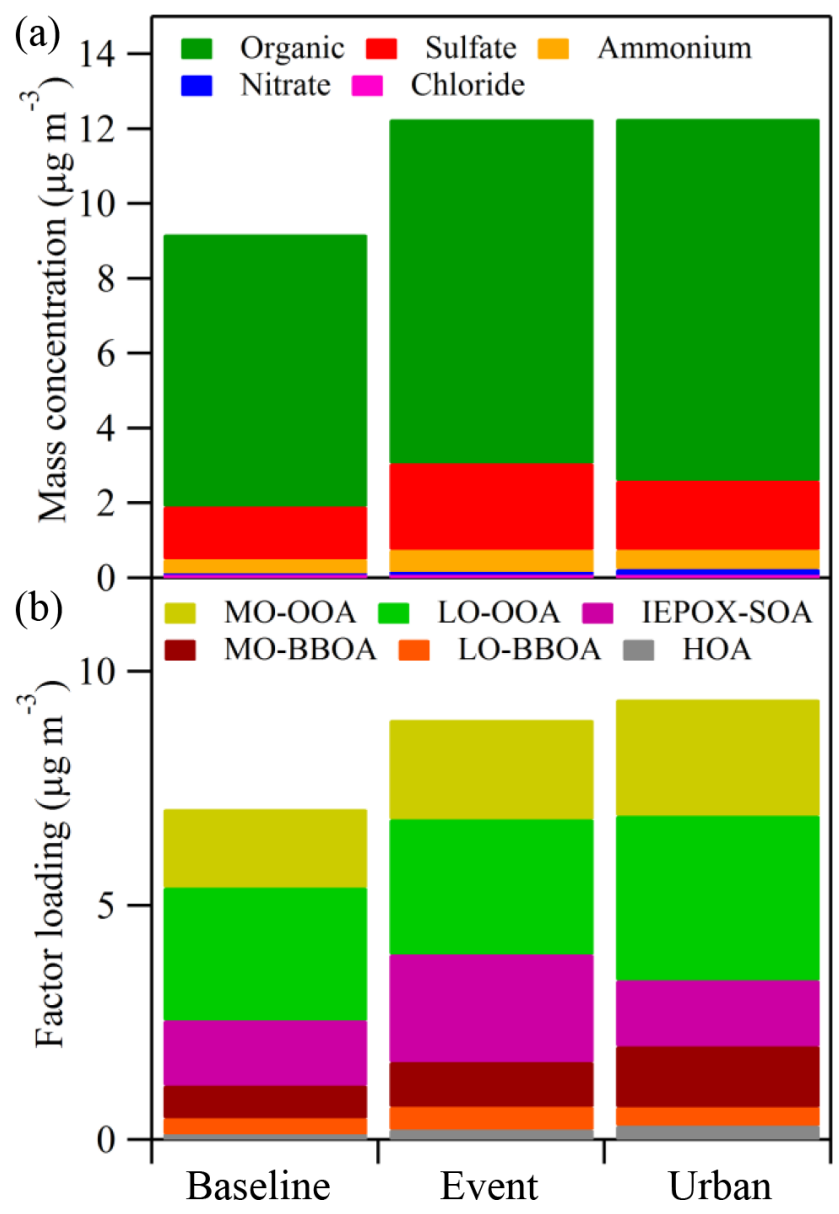

Figure 10. $\mathrm{PM}_{1}$ characterization represented by the centroids of the FCM clusters. (a) Mass concentrations of AMS species. (b) PMF factor loadings. Results are for afternoon time periods. Table S1 lists the values presented in this figure.

of the fractional contribution of $\mathrm{BrC}$ to the total absorption, represented by $b_{\mathrm{abs}, \mathrm{BrC}} / b_{\mathrm{abs}}$, was smaller than the variability of its components $b_{\mathrm{abs}}$ and $b_{\mathrm{abs}, \mathrm{BrC}}$ (i.e., Fig. 11c compared to Fig. 11a-b). The absorptive contributions of $\mathrm{BC}$ and $\mathrm{BrC}$ thus co-varied to some extent, suggesting a partial overlap in sources, which is consistent with previous studies (Collier et al., 2016; Jen et al., 2019). Furthermore, the fractional contribution $b_{\mathrm{abs}, \mathrm{BrC}} / b_{\mathrm{abs}}$ increased from 0.2 in the day to 0.4 at night. The absorption Ångström exponent $\stackrel{\circ}{a b s}_{\text {abs }}$ followed a similar diel trend, on average ranging from 2 during the day to 3 during the night (Fig. 11d). Compared to the diel trends of the six PMF factor loadings, the diel trends of the absorption properties were most similar to those of the MO-BBOA, LO-BBOA, and HOA factors (Fig. 5b).

Figure 12 illustrates connections between $b_{\mathrm{abs}, \mathrm{BrC}}$ and the organic $\mathrm{PM}_{1}$ chemical composition. $\mathrm{BrC}$ light absorption decreases for increases in the $\mathrm{O}: \mathrm{C}$ ratio (Fig. 12a). Conversely, light absorption increases for decreases in the concentration of nitrogen-containing species, as represented by the 

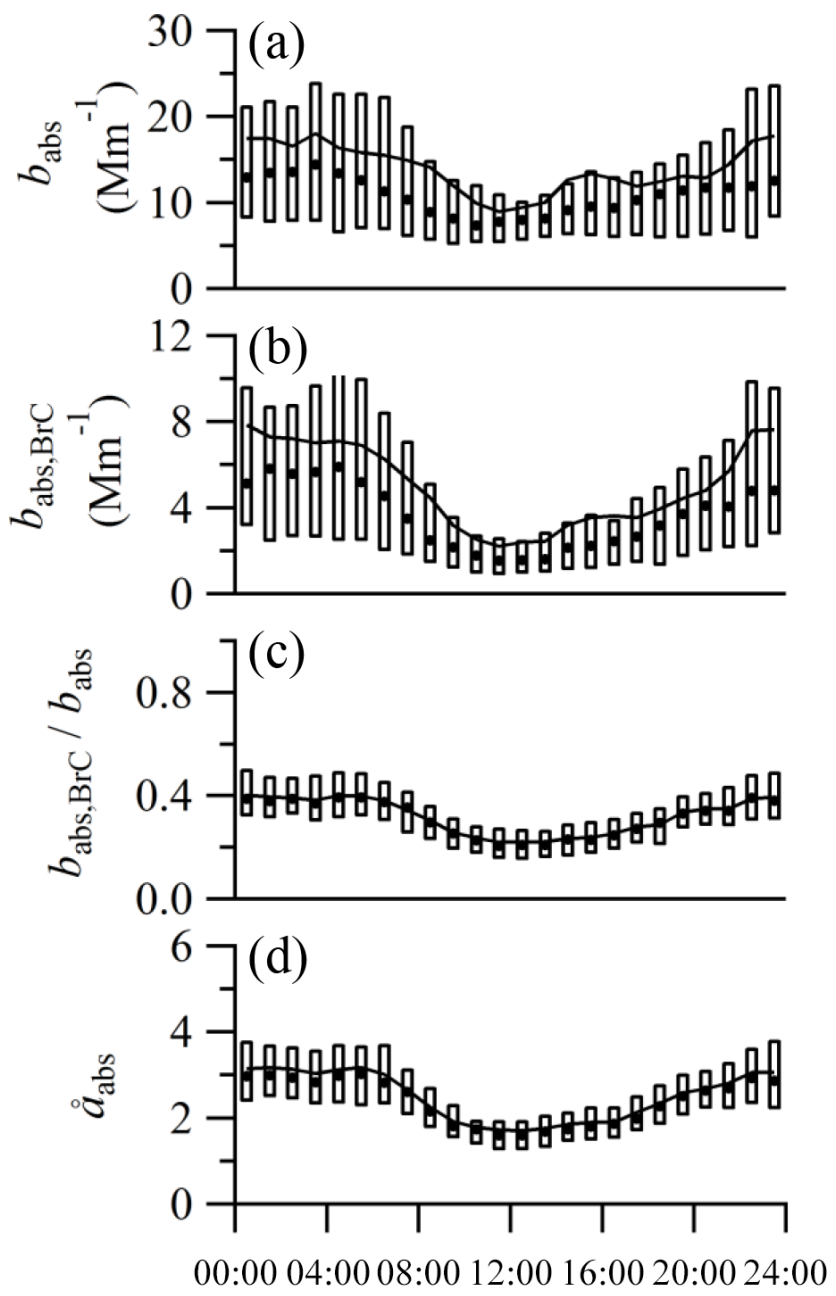

Local hour

Figure 11. Diel trends of $\mathrm{PM}_{1}$ optical properties. (a) Total absorption coefficient $b_{\mathrm{abs}}(370 \mathrm{~nm})$. (b) Absorption coefficient $b_{\mathrm{abs}, \mathrm{BrC}}$ of brown carbon $(370 \mathrm{~nm})$. (c) Fractional contribution of $b_{\mathrm{abs}, \mathrm{BrC}}$ to $b_{\text {abs }}$. (d) Absorption Ångström exponent $\stackrel{\circ}{a}_{\text {abs }}$ from 370 to $430 \mathrm{~nm}$. Local time is UTC minus $4 \mathrm{~h}$.

$\mathrm{C}_{x} \mathrm{H}_{y} \mathrm{O}_{z} \mathrm{~N}_{p}^{+}$family (Fig. 12b). In addition, light absorption increases as the fractional contribution of the $\mathrm{C}_{x} \mathrm{H}_{y} \mathrm{O}_{z} \mathrm{~N}_{p}^{+}$ family to organic $\mathrm{PM}_{1}$ increases and that of the $\mathrm{C}_{x} \mathrm{H}_{y} \mathrm{O}_{z}^{+}$ family decreases (Fig. S14). The diel trends of Fig. 11 and the $\mathrm{O}: \mathrm{C}$ ratios of Fig. 12a support an association of $\mathrm{BrC}$ light absorption with HOA and LO-BBOA factor loadings. These factors had the lowest $\mathrm{O}: \mathrm{C}$ values (Table 1), and they are associated with recent urban and biomass-burning emissions, which are typically important sources of brown carbon (Laskin et al., 2015, and references therein).

The decrease in $b_{\mathrm{abs}, \mathrm{BrC}}$ as $\mathrm{O}: \mathrm{C}$ increases suggests that the atmospheric processing of organic material bleaches the $\mathrm{BrC}$ components under the conditions of central Amazonia. This behavior has been observed in several laboratory studies: $\mathrm{BrC}$ species and thus their optical properties can be mod- ified through atmospheric processing, which may involve reactions at the gas-particle interface, reactions in the aqueous phase of particle and cloud droplets, and photolysis driven by sunlight (Laskin et al., 2015; Zhao et al., 2015; Sumlin et al., 2017; Lee et al., 2014; Romonosky et al., 2015). In addition, Saleh et al. (2014) provided evidence that both primary and secondary material from biomass burning may absorb light, and that the secondary component may be less absorptive than the primary component in the visible spectral range. Lin et al. (2016) found that the absorbance at $300 \mathrm{~nm}$ by biomassburning particles decayed with a half-life of approximately $16 \mathrm{~h}$ against photolysis under typical atmospheric conditions. Forrister et al. (2015) followed plumes from wildfires aboard an aircraft during the 2013 NASA SEAC4RS mission over the continental US and estimated a half-life of 9 to $15 \mathrm{~h}$ for the decay of $\mathrm{BrC}$ light absorption in the plumes.

An important contribution of nitrogen-containing organic molecules to $b_{\mathrm{abs}, \mathrm{BrC}}$ is suggested by the relationship in Fig. 12b. The percent contribution of the $\mathrm{C}_{x} \mathrm{H}_{y} \mathrm{O}_{z} \mathrm{~N}_{p}^{+}$family to each PMF factor profile is listed in Table 2 and is highest for the HOA and LO-BBOA factors. The correlations of factor loadings with the $\mathrm{C}_{x} \mathrm{H}_{y} \mathrm{O}_{z} \mathrm{~N}_{p}^{+}$mass concentrations as well as with the $b_{\text {abs, } \mathrm{BrC}}$ values are highest for these two factors ( $R>0.8$ and $R>0.6$, respectively) (Table 2). The correlations of the MO-BBOA factor loading with these two parameters are lower but still significant. By comparison, the corresponding correlations for the IEPOX-SOA, LO-OOA, and MO-OOA factor loadings are all lower than 0.5. These results further support that the HOA and LO-BBOA factors to a larger extent and the MO-BBOA factor to a lesser extent were tightly associated with nitrogen-containing, lightabsorbing organic molecules.

In contrast to the $\mathrm{C}_{x} \mathrm{H}_{y} \mathrm{O}_{z} \mathrm{~N}_{p}^{+}$family, the correlations between PMF factor loadings and mass concentrations of organic nitrates are low $(R<0.4$, Table 2; Fig. S12). For the HOA, LO-OOA, and MO-OOA factors associated with $\mathrm{BrC}$ light absorption, the correlations are small $(R<0.25)$. The implication could be that the $\mathrm{C}_{x} \mathrm{H}_{y} \mathrm{O}_{z} \mathrm{~N}_{p}^{+}$family is closely tied to $\mathrm{PM}_{1}$ constituted by reduced nitrogen compounds and nitrogen-aromatic compounds. By comparison, organic nitrates are more strongly tied to photochemical production of secondary $\mathrm{PM}_{1}$ and represent more-oxidized forms of nitrogen, including in aliphatic molecules.

Several studies have suggested that nitrogen-containing organic molecules are important absorbers in organic PM (Sun et al., 2007; Lin et al., 2016). Claeys et al. (2012) characterized humic-like substances (HULIS) present in PM collected during the biomass-burning season in Amazonia and identified nitro-aromatic catechols and aromatic carboxylic acids among the main constituents. Nitrophenol derivatives have been identified as major $\mathrm{BrC}$ components in several other urban and rural locations worldwide (Kitanovski et al., 2012; Desyaterik et al., 2013; Kahnt et al., 2013; Mohr et al., 2013). Importantly, Lin et al. (2016) further verified that compounds that are usually interpreted as secondary, such as 

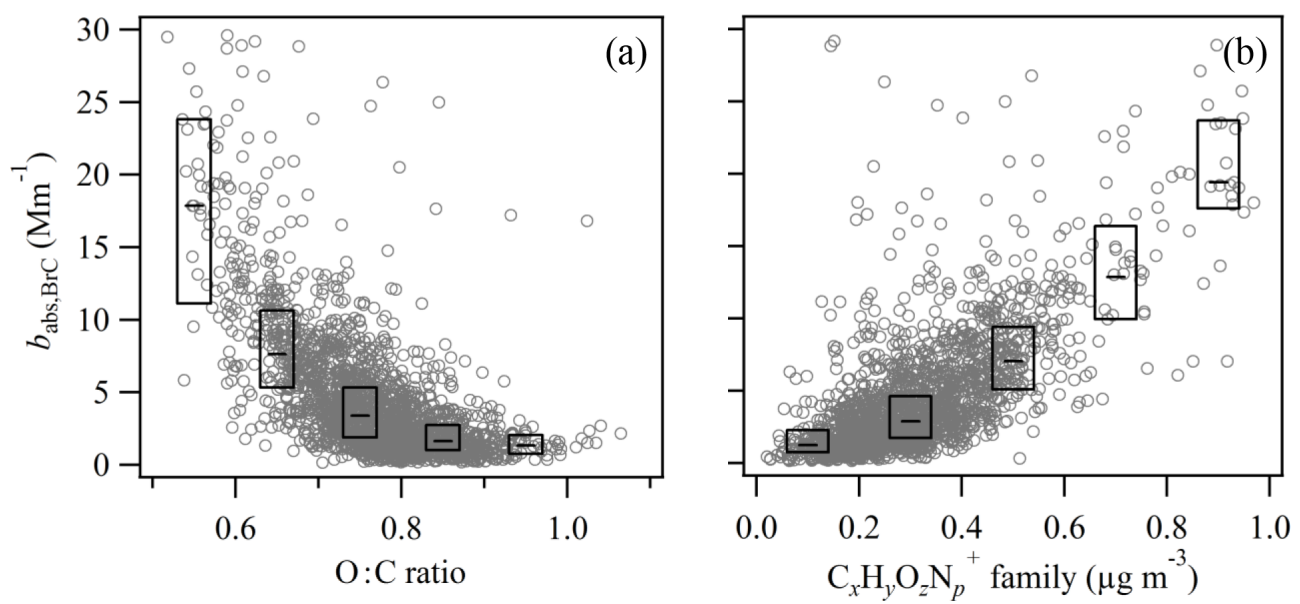

Figure 12. Relationships between the $\mathrm{BrC}$ absorption coefficient and the organic $\mathrm{PM}_{1}$ composition. Scatter plots of $b_{\text {abs, } \mathrm{BrC}}$ against (a) the $\mathrm{O}: \mathrm{C}$ ratio and (b) the mass concentration of the nitrogen-containing $\mathrm{C}_{x} \mathrm{H}_{y} \mathrm{O}_{z} \mathrm{~N}_{p}^{+}$family. For the $\mathrm{C}_{x} \mathrm{H}_{y} \mathrm{O}_{z} \mathrm{~N}_{p}^{+}$family, all ions contain at least one $\mathrm{C}$ atom and one $\mathrm{N}$ atom, meaning $x>0, y \geq 0, z \geq 0$, and $p>0$. Boxes indicate interquartile ranges, and horizontal lines within the boxes indicate medians. For panel (a), each bin width is 0.1 , from 0.5 to 1.0 , and for panel (b), each bin width is 0.2 , from 0 to 1.0 . In complement, Fig. S14 shows the relationships between the $\mathrm{BrC}$ absorption coefficient and the fractional contributions of the $\mathrm{C}_{x} \mathrm{H}_{y} \mathrm{O}_{z}^{+}$and $\mathrm{C}_{x} \mathrm{H}_{y} \mathrm{O}_{z} \mathrm{~N}_{\mathrm{p}}^{+}$families to organic $\mathrm{PM}_{1}$.

Table 2. Relationship of PMF factors to organonitrogen characteristics. Listed for each factor are the mean loading of the time series, the percent contribution of the $\mathrm{C}_{x} \mathrm{H}_{y} \mathrm{O}_{z} \mathrm{~N}_{p}^{+}$family to the factor profile, and the mean mass concentration of the $\mathrm{C}_{x} \mathrm{H}_{y} \mathrm{O}_{z} \mathrm{~N}_{p}^{+}$family (based on multiplication of columns 2 and 3), as well as the Pearson $R$ correlation of factor loading against the mass concentration of $\mathrm{C}_{x} \mathrm{H}_{y} \mathrm{O}_{z} \mathrm{~N}_{p}^{+}$, the mass concentration of organic nitrates, and $b_{\mathrm{abs}, \mathrm{BrC}}$. The $\mathrm{C}_{x} \mathrm{H}_{y} \mathrm{O}_{z} \mathrm{~N}_{p}^{+}$family corresponds to the sum of all ions containing at least one $\mathrm{C}$ atom and one $\mathrm{N}$ atom, as measured by the AMS. Detailed family-colored spectra showing the nitrogen-containing ions for all PMF factors are presented in Fig. S6, and the most important ion fits are shown in Fig. S7. The AMS method characterizes organic nitrates through the $\mathrm{NO}^{+}$and $\mathrm{NO}_{2}^{+}$fragments, which remain distinct from the larger fragments of the $\mathrm{C}_{x} \mathrm{H}_{y} \mathrm{O}_{z} \mathrm{~N}_{p}^{+}$family (Sect. S1 and discussion therein).

\begin{tabular}{|c|c|c|c|c|c|c|}
\hline \multirow[t]{2}{*}{$\begin{array}{l}\text { PMF } \\
\text { factor }\end{array}$} & \multirow[t]{2}{*}{$\begin{array}{l}\text { Mean factor loading } \\
\qquad\left(\mu \mathrm{g} \mathrm{m}^{-3}\right)\end{array}$} & \multicolumn{2}{|c|}{$\begin{array}{l}\text { Nitrogen characteristics of } \\
\text { factor profile }\end{array}$} & \multicolumn{3}{|c|}{ Pearson $R$ of factor loading } \\
\hline & & $\begin{array}{r}\mathrm{C}_{x} \mathrm{H}_{y} \mathrm{O}_{z} \mathrm{~N}_{p}^{+} \text {family } \\
\text { contribution } \\
(\%)\end{array}$ & $\begin{array}{l}\text { Mass concentration } \\
\text { of the } \mathrm{C}_{x} \mathrm{H}_{y} \mathrm{O}_{z} \mathrm{~N}_{p}^{+} \\
\quad \text { family }\left(\mu \mathrm{g} \mathrm{m}^{-3}\right)\end{array}$ & $\begin{array}{r}\text { Against the mass } \\
\text { concentration of } \\
\mathrm{C}_{x} \mathrm{H}_{y} \mathrm{O}_{z} \mathrm{~N}_{p}^{+} \text {family }\end{array}$ & $\begin{array}{l}\text { Against the mass } \\
\text { concentration of } \\
\text { organic nitrates }\end{array}$ & $\begin{array}{l}\text { Against } \\
b_{\mathrm{abs}, \mathrm{BrC}}\end{array}$ \\
\hline MO-OOA & 1.6 & 5.7 & 0.09 & 0.33 & 0.38 & 0.17 \\
\hline LO-OOA & 2.2 & 3.7 & 0.08 & 0.10 & 0.15 & -0.19 \\
\hline IEPOX-SOA & 1.2 & 6.6 & 0.08 & 0.39 & 0.40 & 0.17 \\
\hline MO-BBOA & 1.5 & 2.9 & 0.04 & 0.65 & 0.24 & 0.53 \\
\hline LO-BBOA & 1.0 & 10.4 & 0.11 & 0.89 & 0.13 & 0.69 \\
\hline $\mathrm{HOA}$ & 0.6 & 9.0 & 0.05 & 0.82 & 0.20 & 0.68 \\
\hline
\end{tabular}

nitro-phenols and derivatives, can be produced in the heatladen, NMVOC-rich, high- $\mathrm{NO}_{x}$ conditions of the biomassburning process, being subsequently emitted as primary material. Furthermore, Yee et al. (2013) observed the quick conversion of guaiacol and syringol to nitro-guaiacol and nitrosyringol, respectively, in the presence of HONO even without heat or photo-oxidation. It is possible that $\mathrm{BrC}$ from other combustion sources could have similar characteristics based on this reasoning, helping to explain the association found in this study between BrC absorption and the LO-BBOA and HOA factors. Regarding the further atmospheric processing of these nitrogen-containing organic compounds, laboratory studies have shown that hydroxy radical oxidation of nitroaromatic species in aqueous solutions leads to fragmentation into smaller organic acids (e.g., oxalic, glycolic, malonic, and isocyanic) or, in general, reduces the size of the conjugated molecular systems, leading to a decrease in light absorption at visible wavelengths (Sumlin et al., 2017; Hems and Abbatt, 2018). These findings may help to explain the bleaching of $\mathrm{BrC}$ as the material becomes more oxidized. In the context of the PMF factors, these smaller later-generation prod- 
ucts may then be associated with the MO-OOA factor or may partition to the gas phase depending on their volatility.

Scatter plots of $\stackrel{\leftrightarrow}{a}_{\text {abs }}$ against markers of biomass burning are shown in Fig. 13. The Pearson $R$ correlations against $\log _{10}\left(f_{60} / f_{44}\right)$ and $\left(\mathrm{BBOA}_{\mathrm{T}} /\right.$ organic $\left.\mathrm{PM}_{1}\right)$ are 0.87 and 0.75 , respectively. The $f_{60} / f_{44}$ ratio is a tracer for the influence of fresh biomass burning, and an association of $\stackrel{\circ}{a b s}_{a}$ and with this quantity was also reported for Boulder, Colorado, USA (Lack et al., 2013). These relationships could be useful parameterizations to estimate $\stackrel{\AA}{a b s}_{\text {abs }}$ when optical measurements are not available but AMS/ACSM measurements are, at least during times of biomass-burning influence in central Amazonia. Worldwide, observed values of $\stackrel{a}{a b s}_{\text {abs }}$ range from $<2$ to 11 for particles tied to biomass burning (Chakrabarty et al., 2010; Saleh et al., 2014). The value of $\stackrel{\circ}{a b s}_{\text {abs }}$ reached 6 for the highest observed values of $\left(f_{60} / f_{44}\right)$. It approached 1.0 in the limit of $f_{60} / f_{44}<0.02$, which indicates little influence of proximate biomass burning (Fig. 13a; cf. upper left of Fig. 7a). Further observations elsewhere in the Amazon and on other regions are needed before the parameterizations

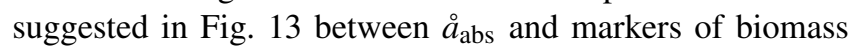
burning can be generalized with confidence.

\subsubsection{Contribution of organic PM components to BrC absorption}

Herein, advantage is taken of the representation of the organic PM in its subcomponents provided by the PMF factors to estimate a mass absorption efficiency for each of them. The absorption coefficient is the sum of the absorption coefficient of the $n$ parts of the organic PM ("Org"):

$b_{\mathrm{abs}, \mathrm{BrC}}=b_{\mathrm{abs}, \operatorname{Org}_{1}}+b_{\mathrm{abs}, \operatorname{Org}_{2}}+\ldots+b_{\mathrm{abs}, \operatorname{Org}_{n}}$.

The treatment assumes the absence of cross-interactions among the parts and holds for a single wavelength. The absorption coefficient $b_{\mathrm{abs}, i}$ of part $i$ is defined as follows:

$b_{\mathrm{abs}, i}=E_{\mathrm{abs}, i} \times C_{i}$,

where $E_{\mathrm{abs}, i}$ is the mass absorption efficiency and $C_{i}$ is the mass concentration of part $i$. Based on Eqs. (3) and (4), the following model was constructed for $b_{\mathrm{abs}, \mathrm{BrC}}$ by using the PMF factor loadings as a proxy for the mass concentrations of organic $\mathrm{PM}_{1}$ components:

$$
\begin{aligned}
b_{\mathrm{abs}, \mathrm{BrC}} & =E_{\mathrm{abs}, \mathrm{MO}-\mathrm{OOA}} G_{\mathrm{MO}-\mathrm{OOA}}+E_{\mathrm{abs}, \mathrm{LO}-\mathrm{OOA}} G_{\mathrm{LO}-\mathrm{OOA}}+ \\
& +E_{\mathrm{abs}, \mathrm{IEPOX}-\mathrm{SOA}} G_{\mathrm{IEPOX}-\mathrm{SOA}}+ \\
& +E_{\mathrm{abs}, \mathrm{MO}-\mathrm{BBOA}} G_{\mathrm{MO}-\mathrm{BBOA}}+ \\
& +E_{\mathrm{abs}, \mathrm{LO}-\mathrm{BBOA}} G_{\mathrm{LO}-\mathrm{BBOA}}+ \\
& +E_{\mathrm{abs}, \mathrm{HOA}} G_{\mathrm{HOA}}+B
\end{aligned}
$$

where $G_{i}$ correspond to loadings of factor $i$, and the unknowns are the mass absorption efficiencies $E_{\mathrm{abs}, i}$ associated with each PMF factor. An intercept $B$ was added to account for the variability not explained by the PMF factors.
Table 3. Results of the constrained linear least-squares regression analysis for the $\mathrm{BrC}$ absorption coefficient (Eq. 5). (a) Mass absorption efficiency $E_{\text {abs }}$ associated with each PMF factor. (b) Model intercept. The mean, standard error (SE), and $95 \%$ confidence interval $(\mathrm{CI})$ are listed in each panel. They were obtained through bootstrap of the regression analysis considering different samples (i.e., sets of points in time) for $10^{4}$ runs. Unit of $\mathrm{Mm}^{-1}$ represents

\begin{tabular}{|c|c|c|c|}
\hline \multirow{2}{*}{$\begin{array}{l}\text { (a) } \\
\text { PMF factors }\end{array}$} & \multicolumn{3}{|c|}{$E_{\text {abs }}\left(\mathrm{m}^{2} \mathrm{~g}^{-1}\right)$} \\
\hline & Mean & SE & CI \\
\hline MO-OOA & $0.01^{*}$ & 0.02 & {$[0.00,0.08]$} \\
\hline LO-OOA & $0.01^{*}$ & 0.02 & {$[0.00,0.08]$} \\
\hline IEPOX-SOA & 0.40 & 0.05 & {$[0.31,0.50]$} \\
\hline MO-BBOA & 0.82 & 0.04 & {$[0.75,0.90]$} \\
\hline LO-BBOA & 1.50 & 0.07 & {$[1.37,1.63]$} \\
\hline $\mathrm{HOA}$ & 2.04 & 0.14 & {$[1.76,2.31]$} \\
\hline (b) & \multicolumn{3}{|c|}{$b_{\text {abs }}\left(\mathrm{Mm}^{-1}\right)$} \\
\hline Model intercept & Mean & SE & $\mathrm{CI}$ \\
\hline$B$ & $0.13^{*}$ & 0.10 & {$[0.00,0.33]$} \\
\hline
\end{tabular}
$10^{-6} \mathrm{~m}^{-1}$. The coefficient of determination $R^{2}$ between predicted $b_{\text {abs,BrC,pred }}$ and observed $b_{\text {abs, BrC }}$ was 0.66 . The symbol “ $*$ " indicates that the estimated value was statistically not higher than zero at the significance level of $5 \%$.

Other studies have also made use of multivariate linear regression to retrieve mass absorption efficiencies (Hand and Malm, 2007; Washenfelder et al., 2015; Ealo et al., 2018).

Estimates of $E_{\mathrm{abs}, i}$ were obtained using a constrained linear least-squares algorithm applied to Eq. (5), where the inputs were the observed $b_{\mathrm{abs}, \mathrm{BrC}}$ and the factor loadings for each point in time during IOP2. The input data are represented in the scatter plots of $G_{i}$ against $b_{\mathrm{abs}, \mathrm{BrC}}$ shown in Fig. 14a to $\mathrm{f}$. A non-negative constraint on the model coefficients $E_{\mathrm{abs}, i}$ was included for physical meaning. The algorithm was applied in bootstrap with replacement of residuals for $10^{4}$ runs, and convergence of the bootstrap results was checked by varying the number of samples. The resulting estimates of mean and standard error of $E_{\text {abs }}$ for all PMF factors are listed in Table 3.

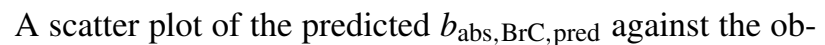
served $b_{\mathrm{abs}, \mathrm{BrC}}$ is shown in Fig. 14h. The model captured $66 \%$ of the variance in $b_{\mathrm{abs}, \mathrm{BrC}}$, and the PMF factor loadings can be considered good predictors of the BrC absorption under the study conditions. Physical factors not directly represented in this statistical model, such as the effects of mixing state, size distribution, and so on for $\mathrm{BrC}$ absorption, either have low variability under the study conditions or alternatively have co-variability also captured in the PMF factor loadings.

The highest values of $E_{\text {abs }}$ at $370 \mathrm{~nm}$ were associated with the HOA and LO-BBOA factors $(2.04 \pm 0.14$ and $1.50 \pm$ $0.07 \mathrm{~m}^{2} \mathrm{~g}^{-1}$, respectively). These results support the inter- 

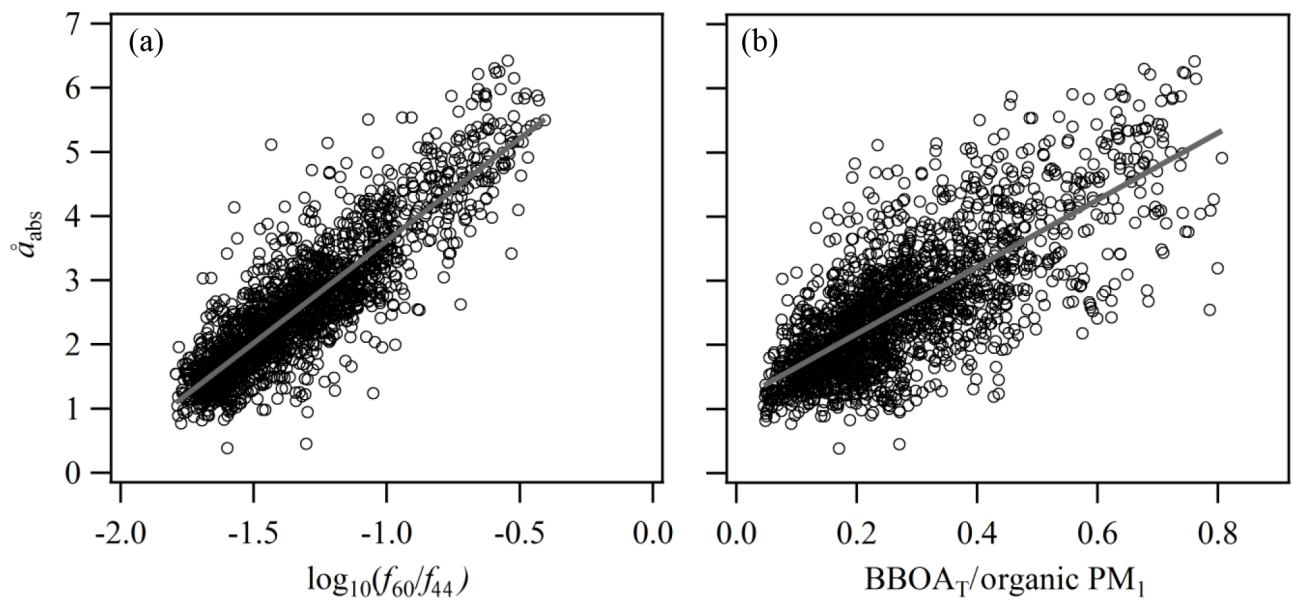

Figure 13. Relationships between the absorption Ångström exponent and indicators of biomass burning. Scatter plots of $\stackrel{\circ}{a}_{\text {abs }}$ against (a) $\log _{10}\left(f_{60} / f_{44}\right)$ of the AMS analysis $(R=0.87)$, and (b) the ratio of the $\mathrm{BBOA}_{\mathrm{T}}$ loading to the organic $\mathrm{PM}_{1} \mathrm{mass}$ concen-

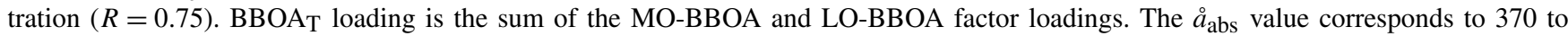
$430 \mathrm{~nm}$. In panel (a), the slope and intercept are $3.2 \pm 0.1$ and $6.8 \pm 0.1$, respectively. In panel (b), they are $5.2 \pm 0.1$ and $1.1 \pm 0.1$.

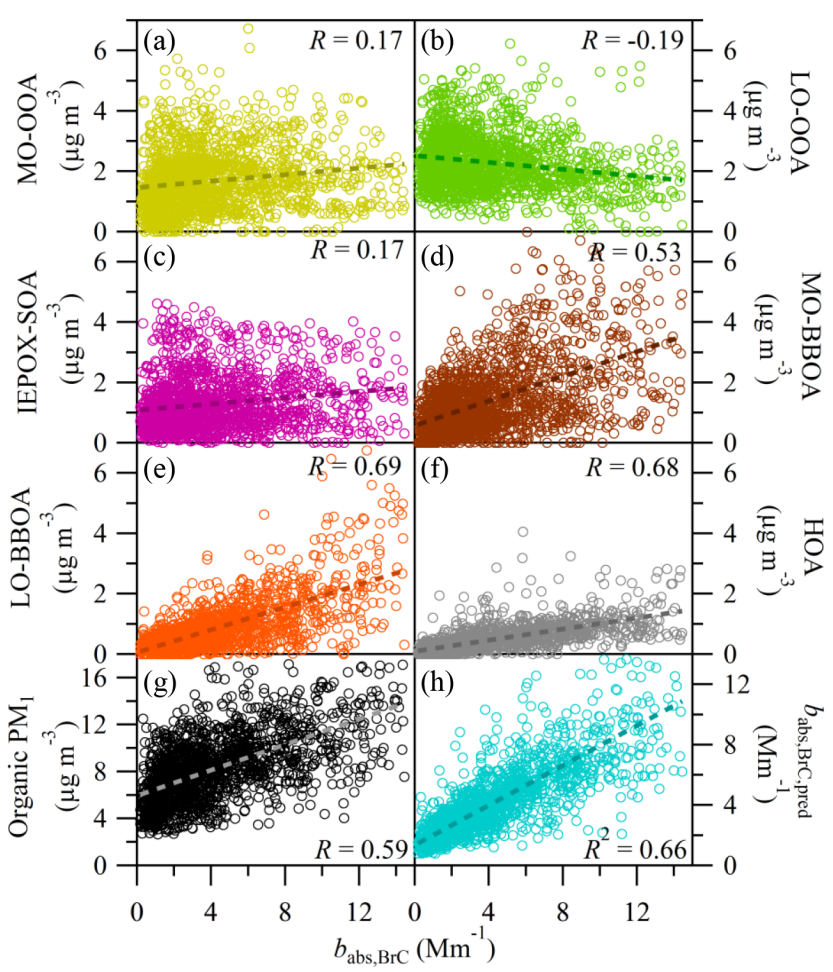

Figure 14. Scatter plots against $b_{\mathrm{abs}, \mathrm{BrC}}$ of (a)-(f) $\mathrm{PMF}$ factor load-

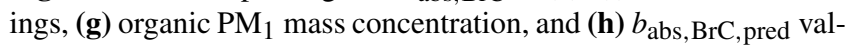
ues predicted by a multivariate linear regression model using PMF factor loadings as parameters as described by Eq. (5).

pretation presented in the previous section about the association of the HOA and LO-BBOA factors with light absorption. As a point of comparison, Ealo et al. (2018) conducted a study in the northwestern Mediterranean and found the highest mass absorption efficiencies, ranging from 0.9 to $1.7 \mathrm{~m}^{2} \mathrm{~g}^{-1}$ at $637 \mathrm{~nm}$, for traffic and industrial sources. As another point of comparison, $E_{\text {abs }}$ of 2 to $3 \mathrm{~m}^{2} \mathrm{~g}^{-1}$ at $300 \mathrm{~nm}$ was reported for HULIS extracts from $\mathrm{PM}_{2.5}$ filter samples collected under biomass-burning conditions during the Amazon dry season in Rondônia, Brazil (Hoffer et al., 2006). HULIS have been recognized as important components of $\mathrm{BrC}$ from biomass burning (Mukai and Ambe, 1986; Andreae and Gelencsér, 2006; Graber and Rudich, 2006). The $E_{\mathrm{abs}}$ value of the MO-BBOA factor was $0.82 \pm$ $0.04 \mathrm{~m}^{2} \mathrm{~g}^{-1}$. The result of $E_{\text {abs,MO-BBOA }}<E_{\text {abs,LO-BBOA }}$ is consistent with an interpretation of photochemically driven oxidation and bleaching during the atmospheric transport of biomass-burning emissions.

The $E_{\mathrm{abs}}$ value of the IEPOX-SOA factor was $0.40 \pm$ $0.05 \mathrm{~m}^{2} \mathrm{~g}^{-1}$, and the $E_{\text {abs }}$ values of the MO-OOA and LOOOA factors $\left(0.01 \pm 0.02 \mathrm{~m}^{2} \mathrm{~g}^{-1}\right)$ were not statistically different from zero. Laboratory studies suggest that biogenic PM does not appreciably absorb light in the near-UV and visible range, although this result may change with atmospheric exposure to ammonia and amines, changes in particle acidity, and other factors (Nakayama et al., 2012; Liu et al., 2013; Flores et al., 2014; Lin et al., 2014; Laskin et al., 2015). Biogenic PM is typically characterized by carbonyls, carboxyls, and hydroxyls without substantial conjugation; this composition does not have the low-energy electronic transitions relevant for $\mathrm{BrC}$ light absorption (Laskin et al., 2015). By contrast, PM produced by the photo-oxidation of aromatic NMVOCs, such as toluene, $m$-xylene, naphthalene, and trimethylbenzene, tends to absorb significantly, and the light absorption is greater for PM produced under conditions of higher $\mathrm{NO}_{x}$ concentrations because of the production of nitro-aromatic compounds (Zhong and Jang, 2011; Liu et al., 2012, 2015; Lee et al., 2014). This absorption, however, 
Table 4. Contribution of $\mathrm{PM}_{1}$ components as represented by the PMF factors to organic mass concentrations and BrC light absorption. The contribution of the model intercept to BrC light absorption is also included. Values listed are resulting means and standard deviations of the contributions calculated throughout IOP2. Small differences between the values in the second column and the values represented in the inset of Fig. 5a are due to differences in data coverage by the aethalometer and AMS.

\begin{tabular}{lrr}
\hline PMF factor & $\begin{array}{r}\text { Contribution } \\
\text { to organic mass } \\
\text { concentration }(\%)\end{array}$ & $\begin{array}{r}\text { Contribution } \\
\text { to BrC light } \\
\text { absorption }(\%)\end{array}$ \\
\hline MO-OOA & $21.1 \pm 10.0$ & $0.5 \pm 0.4$ \\
LO-OOA & $30.9 \pm 11.4$ & $0.8 \pm 0.5$ \\
IEPOX-SOA & $16.3 \pm 9.8$ & $15.7 \pm 11.2$ \\
MO-BBOA & $16.7 \pm 12.0$ & $28.9 \pm 18.0$ \\
LO-BBOA & $9.5 \pm 7.5$ & $27.8 \pm 14.3$ \\
HOA & $5.5 \pm 3.9$ & $21.7 \pm 10.5$ \\
Model intercept & $\mathrm{n} / \mathrm{a}$ & $4.6 \pm 2.6$ \\
\hline
\end{tabular}

may decrease with atmospheric processing as previously discussed for the case of biomass-burning emissions, which is also reflected in the negligible value of $E_{\text {abs }}$ for MO-OOA. In central Amazonia, the organic PM is dominated by biogenic forest precursors even in the pollution plume of Manaus, which helps to explain the negligible $E_{\text {abs }}$ value for LOOOA. It may also be that some aromatic PM is associated with the HOA factor, which has a high $E_{\text {abs }}$ value.

A comparison of the relative contributions of PMF factor loadings to organic $\mathrm{PM}_{1}$ mass concentration and to light absorption is presented in Fig. 15 ( $a$ and b, respectively). The contribution of each class of organic compounds to total absorption by organic $\mathrm{PM}_{1}$ was estimated for each point in time by multiplication of the $E_{\text {abs }}$ value and the loading of each PMF factor during IOP2. The means and standard deviations of the resulting percentage contributions are listed in Table 4. Biomass-burning and urban emissions, as represented by the BBOA and HOA factors, appeared to contribute $80 \%$ of $b_{\text {abs, } \mathrm{BrC}}$ while accounting for at least $30 \%$ of the organic $\mathrm{PM}_{1}$ mass concentration. The IEPOX-SOA factor was associated with the balance of $b_{\mathrm{abs}, \mathrm{BrC}}$ while representing $16 \%$ of the organic $\mathrm{PM}_{1}$ mass concentration. Studies with further information on black carbon size distribution, particle mixing state, and the effect of RH on particle absorption are warranted to refine the estimates of $E_{\text {abs }}$ for the components of organic $\mathrm{PM}_{1}$ and therefore their contributions to $\mathrm{BrC}$ light absorption. A similar attribution analysis to the one in Fig. 15b was carried out for the baseline, event, and urban clusters separately and is discussed in the Supplement (Fig. S15).

The BrC light absorption can have direct and indirect effects on radiative forcing, which ought to be further investigated for the Amazon region. The inclusion of $\mathrm{BrC}$ absorption in models may result in a positive direct radiative forcing

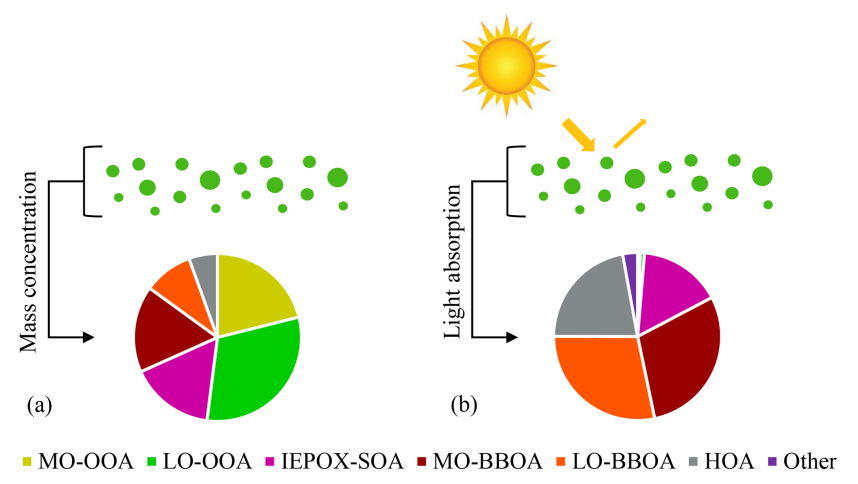

Figure 15. Comparative relationship of the relative contributions of PMF factor loadings to (a) organic $\mathrm{PM}_{1}$ mass concentration and (b) organic $\mathrm{PM}_{1}$ light absorption. Results represent means for the full data sets of IOP2. The means and standard deviations are listed in Table 4. Results are for $370 \mathrm{~nm}$. "Other" refers to the model intercept $B$ (Eq. 5).

(DRF) in regions of high $\mathrm{BrC}$ concentrations, in contrast to models that assume organic PM as a purely scattering component (Ramanathan and Carmichael, 2008; Myhre et al., 2013). Recent models have estimated the global BrC contribution to DRF to be in the range of 0.1 to $0.25 \mathrm{~W} \mathrm{~m}^{-2}$, corresponding to $10 \%$ to $25 \%$ of the DRF by BC (Feng et al., 2013). In addition, $\mathrm{BrC}$ in cloud water can absorb light and thereby facilitate water evaporation and cloud dispersion (Hansen et al., 1997). This effect may compensate the cooling that aerosol particles offer by serving as seeds for cloud droplet formation and may also provide a positive feedback as increased fire activity may provoke more fire-prone conditions by suppressing precipitation (Nepstad et al., 1999; Bevan et al., 2009; Gonçalves et al., 2015; Laskin et al., 2015). Another implication is that light absorption by $\mathrm{BrC}$ in the ultraviolet may significantly decrease photolysis rates, thereby affecting the concentrations of precursors and oxidants such as ozone and $\mathrm{OH}$ radicals in the atmosphere (Li et al., 2011; Jiang et al., 2012; Laskin et al., 2015).

\section{Summary and conclusions}

The influence of urban and biomass-burning emissions on the otherwise natural concentrations, composition, and optical properties of organic $\mathrm{PM}_{1}$ in central Amazonia were investigated during the dry season. Positive-matrix factorization was used to classify the organic PM into subcomponents. The MO-OOA, LO-OOA, and IEPOX-SOA together accounted for about $62 \%$ of the organic PM. The MO-BBOA and LOBBOA factors together accounted for $31 \%$, and HOA for the remaining $7 \%$. An important conclusion is that the 8.5 -fold increase in organic $\mathrm{PM}_{1}$ concentrations between the wet and dry seasons is not all due to biomass burning but also to a concurrent increase of biogenic secondary organic $\mathrm{PM}_{1}$ of 8fold and smaller increases in urban $\mathrm{PM}_{1}$. Reasons that pos- 
sibly played a role in such increases for the dry season are increased BVOC emissions, increased formation potential of biogenic secondary organic $\mathrm{PM}_{1}$, reduced wet and dry deposition and PBL ventilation of $\mathrm{PM}_{1}$ particles, and increased partitioning due to larger organic $\mathrm{PM}_{1}$ mass concentrations in the dry season.

The FCM clustering analysis identified the baseline, event, and urban clusters. Relative to the baseline cluster $\left(9.2 \mu \mathrm{g} \mathrm{m}^{-3}\right)$, both the event and the urban cluster had an increase of $3 \mu \mathrm{g} \mathrm{m}^{-3}$. For the event cluster, the increased sulfate concentrations together with only moderate increases in $\mathrm{NO}_{y}$, resulted in remarkable increases of almost $1 \mu \mathrm{g} \mathrm{m}^{-3}$ $(65 \%)$ in IEPOX-SOA factor loadings relative to the baseline cluster. Regarding the urban cluster, increases in the factor loadings of MO-BBOA ( $40 \%$ to $90 \%$ ) and LO-OOA (20\% to $25 \%$ ) were observed in comparison to the other two clusters. At the same time, the IEPOX-SOA contribution was either the same or lower (by $40 \%$ ) in absolute loadings and always lower in relative contribution to organic PM (15\% of organic PM compared to $20 \%-30 \%$ for the other clusters). These changes in the makeup of organic PM were consistent with the changes observed for the wet season (de Sá et al., 2017, 2018). They were attributed partly to (i) a shift in oxidation pathways from $\mathrm{HO}_{2}$ - to NO-dominant, and partly to (ii) an accelerated oxidation cycle that increases the mass concentration of secondary organic PM.

Optical properties of the $\mathrm{PM}_{1}$ were investigated, focusing on the organic component. The $\mathrm{BrC}$ absorption coefficient $\left(b_{\mathrm{abs}, \mathrm{BrC}}\right)$ had an inverse relationship with the $\mathrm{O}: \mathrm{C}$ ratio and a positive relationship with the $\mathrm{C}_{x} \mathrm{H}_{y} \mathrm{O}_{z} \mathrm{~N}_{p}^{+}$family, indicating that $\mathrm{BrC}$ light in this region was associated with less-oxidized and $\mathrm{N}$-containing organic compounds. The LO-BBOA and HOA factors had the lowest $\mathrm{O}: \mathrm{C}$ ratios and highest relative contribution of $\mathrm{C}_{x} \mathrm{H}_{y} \mathrm{O}_{z} \mathrm{~N}_{p}^{+}$family ions, suggesting that these factors represent $\mathrm{BrC}$ components. In addition, a tight relationship between $\stackrel{\circ}{a b s}_{a}$ and $\log _{10}\left(f_{60} / f_{44}\right)$ was found, corroborating the importance of BBOA factors for absorption properties of organic PM, and possibly providing a parameterization for $\stackrel{\circ}{a}_{\mathrm{abs}}$ in the region. Further analysis determined the $E_{\mathrm{abs}}$ associated with each of the PMF factors. The results implied that the MO-OOA and LO-OOA factors were associated with non-absorbing components. The MO-BBOA $\left(E_{\mathrm{abs}}=0.8 \mathrm{~m}^{2} \mathrm{~g}^{-1}\right)$, LO-BBOA $\left(1.5 \mathrm{~m}^{2} \mathrm{~g}^{-1}\right)$, and HOA $\left(2.0 \mathrm{~m}^{2} \mathrm{~g}^{-1}\right)$ factors were associated with $80 \%$ of the light absorption by organic PM in the region. The remaining absorption $(<10 \%)$ was attributed to IEPOX-SOA $\left(E_{\text {abs }}=0.4 \mathrm{~m}^{2} \mathrm{~g}^{-1}\right)$.

Given the importance of biomass burning and the increasing importance of urban pollution in the Amazon forest, light absorption by atmospheric particulate matter could become more prevalent in this region in the future. Further field, laboratory, and modeling studies are warranted to (i) more finely map the importance of both urban and biomassburning emissions at different locations in the Amazon region, (ii) characterize $\mathrm{BrC}$ components at the molecular level for structure-absorption relationships, and (iii) quantify the effects of $\mathrm{BrC}$ absorption on radiative forcing in the regional and global scales for current and future scenarios of increased human impacts.

Data availability. The data sets used in this publication are available at the ARM Climate Research Facility database for the GoAmazon2014/5 experiment (https://www.arm.gov/research/ campaigns/amf2014goamazon, last access: 1 August 2018).

Supplement. The supplement related to this article is available online at: https://doi.org/10.5194/acp-19-7973-2019-supplement.

Author contributions. SSdS, LVR, and STM defined the scientific questions and scope of this study. STM, JLJ, MLA, AHG, and PA designed, planned, and supervised the broader GoAmazon2014/5 field experiment. SSdS, BBP, PCJ, and DAD carried out the AMS measurements and data processing. AS collected and quality checked the aethalometer data. LVR performed the $\mathrm{BrC}$ calculations based on the aethalometer data. LDY, RW, GYV, JB, SC, YJL, SS, and HMJB performed auxiliary data collection/processing and simulations. SSdS carried out the scientific analysis involving PMF and FCM. SSdS prepared the paper with contributions from all co-authors.

Competing interests. The authors declare that they have no conflict of interest.

Special issue statement. This article is part of the special issue "Observations and Modeling of the Green Ocean Amazon (GoAmazon2014/5) (ACP/AMT/GI/GMD inter-journal SI)". It is not associated with a conference.

Acknowledgements. Institutional support was provided by the central office of the Large-Scale Biosphere-Atmosphere Experiment in Amazonia (LBA), the National Institute of Amazonian Research (INPA), and Amazonas State University (UEA). Suzane S. de Sá acknowledges support by the Faculty for the Future Fellowship of the Schlumberger Foundation. Brett B. Palm acknowledges a US EPA STAR graduate fellowship (FP-91761701-0). This paper has not been reviewed by EPA and no endorsement should be inferred. Data access from the Sistema de Proteção da Amazônia (SIPAM) is gratefully acknowledged. The research was conducted under scientific license 001030/2012-4 of the Brazilian National Council for Scientific and Technological Development (CNPq).

Financial support. This research has been supported by the Atmospheric Radiation Measurement (ARM) Climate Research Facility, a user facility of the United States Department of Energy (DOE, DE-SC0006680), Office of Science, sponsored by the Office of Biological and Environmental Research, and support from the Atmo- 
spheric System Research (ASR, DE-SC0011115, DE-SC0011105) program of that office. Additional funding was provided by the Amazonas State Research Foundation (FAPEAM 062.00568/2014 and FAPEAM 134/2016), the São Paulo State Research Foundation (grant nos. FAPESP 2013/05014-0, FAPESP 2017/170470, FAPESP 2013/50510-5, and FAPESP 2013/10156-8), the US National Science Foundation (grant nos. 1106400 and 1332998), and the Brazilian Scientific Mobility Program (CsF/CAPES). Brett B. Palm, Pedro Campuzano-Jost, Douglas A. Day, and Jose L. Jimenez were supported by DOE (BER/ASR (grant no. DESC0016559) and NSF (grant no. AGS-1822664)).

Review statement. This paper was edited by Thomas Karl and reviewed by two anonymous referees.

\section{References}

Alves, E. G., Jardine, K., Tota, J., Jardine, A., Yãnez-Serrano, A. M., Karl, T., Tavares, J., Nelson, B., Gu, D., Stavrakou, T., Martin, S., Artaxo, P., Manzi, A., and Guenther, A.: Seasonality of isoprenoid emissions from a primary rainforest in central Amazonia, Atmos. Chem. Phys., 16, 3903-3925, https://doi.org/10.5194/acp-16-3903-2016, 2016.

Ammerlaan, B. A. J., Holzinger, R., Jedynska, A. D., and Henzing, J. S.: Aerosol light absorption measurements with a carbon analyser - Calibration and precision estimates, Atmos. Environ., 164, 1-7, https://doi.org/10.1016/j.atmosenv.2017.05.031, 2017.

Andreae, M. O. and Gelencsér, A.: Black carbon or brown carbon? The nature of light-absorbing carbonaceous aerosols, Atmos. Chem. Phys., 6, 3131-3148, https://doi.org/10.5194/acp-63131-2006, 2006.

Andreae, M. O. and Merlet, P.: Emission of trace gases and aerosols from biomass burning, Global Biogeochem. Cy., 15, 955-966, https://doi.org/10.1029/2000GB001382, 2001.

Andreae, M. O., Berresheim, H., Bingemer, H., Jacob, D. J., Lewis, B. L., Li, S. M., and Talbot, R. W.: The atmospheric sulfur cycle over the Amazon Basin: 2. Wet season, J. Geophys. Res.-Atmos., 95, 16813-16824, https://doi.org/10.1029/JD095iD10p16813, 1990.

Andreae, M. O., Artaxo, P., Brandão, C., Carswell, F. E., Ciccioli, P., da Costa, A. L., Culf, A. D., Esteves, J. L., Gash, J. H. C., Grace, J., Kabat, P., Lelieveld, J., Malhi, Y., Manzi, A. O., Meixner, F. X., Nobre, A. D., Nobre, C., Ruivo, M. d. L. P., Silva-Dias, M. A., Stefani, P., Valentini, R., von Jouanne, J., and Waterloo, M. J.: Biogeochemical cycling of carbon, water, energy, trace gases, and aerosols in Amazonia: The LBA-EUSTACH experiments, J. Geophys. Res.-Atmos., 107, LBA 33-31-LBA 33-25, https://doi.org/10.1029/2001JD000524, 2002.

Andreae, M. O., Rosenfeld, D., Artaxo, P., Costa, A. A., Frank, G. P., Longo, K. M., and Silva-Dias, M. A. F.: Smoking rain clouds over the Amazon, Science, 303, 1337-1342, https://doi.org/10.1126/science.1092779, 2004.

Andreae, M. O., Acevedo, O. C., Araùjo, A., Artaxo, P., Barbosa, C. G. G., Barbosa, H. M. J., Brito, J., Carbone, S., Chi, X., Cintra, B. B. L., da Silva, N. F., Dias, N. L., Dias-Júnior, C. Q., Ditas, F., Ditz, R., Godoi, A. F. L., Godoi, R. H. M., Heimann, M., Hoffmann, T., Kesselmeier, J., Könemann, T., Krüger, M. L., Lavric,
J. V., Manzi, A. O., Lopes, A. P., Martins, D. L., Mikhailov, E. F., Moran-Zuloaga, D., Nelson, B. W., Nölscher, A. C., Santos Nogueira, D., Piedade, M. T. F., Pöhlker, C., Pöschl, U., Quesada, C. A., Rizzo, L. V., Ro, C.-U., Ruckteschler, N., Sá, L. D. A., de Oliveira Sá, M., Sales, C. B., dos Santos, R. M. N., Saturno, J., Schöngart, J., Sörgel, M., de Souza, C. M., de Souza, R. A. F., Su, H., Targhetta, N., Tóta, J., Trebs, I., Trumbore, S., van Eijck, A., Walter, D., Wang, Z., Weber, B., Williams, J., Winderlich, J., Wittmann, F., Wolff, S., and Yáñez-Serrano, A. M.: The Amazon Tall Tower Observatory (ATTO): overview of pilot measurements on ecosystem ecology, meteorology, trace gases, and aerosols, Atmos. Chem. Phys., 15, 10723-10776, https://doi.org/10.5194/acp-15-10723-2015, 2015.

Aragão, L. E. O. C., Poulter, B., Barlow, J. B., Anderson, L. O., Malhi, Y., Saatchi, S., Phillips, O. L., and Gloor, E.: Environmental change and the carbon balance of Amazonian forests, Biol. Rev., 89, 913-931, https://doi.org/10.1111/brv.12088, 2014.

Artaxo, P., Gerab, F., Yamasoe, M. A., and Martins, J. V.: Fine mode aerosol composition at three long-term atmospheric monitoring sites in the Amazon Basin, J. Geophys. Res.-Atmos., 99, 2285722868, https://doi.org/10.1029/94JD01023, 1994.

Artaxo, P., Martins, J. V., Yamasoe, M. A., Procópio, A. S., Pauliquevis, T. M., Andreae, M. O., Guyon, P., Gatti, L. V., and Leal, A. M. C.: Physical and chemical properties of aerosols in the wet and dry seasons in Rondônia, Amazonia, J. Geophys. Res.-Atmos., 107, LBA 49-41-LBA 49-14, https://doi.org/10.1029/2001JD000666, 2002.

Artaxo, P., Rizzo, L. V., Brito, J. F., Barbosa, H. M. J., Arana, A., Sena, E. T., Cirino, G. G., Bastos, W., Martin, S. T., and Andreae, M. O.: Atmospheric aerosols in Amazonia and land use change: from natural biogenic to biomass burning conditions, Faraday Discuss., 165, 203-235, https://doi.org/10.1039/C3FD00052D, 2013.

Bahadur, R., Praveen, P. S., Xu, Y., and Ramanathan, V.: Solar absorption by elemental and brown carbon determined from spectral observations, P. Natl. Acad. Sci. USA, 109, 17366-17371, https://doi.org/10.1073/pnas.1205910109, 2012.

Bevan, S., L., North, P. R. J., Grey, W. M. F., Los Sietse, O., and Plummer, S. E.: Impact of atmospheric aerosol from biomass burning on Amazon dry-season drought, J. Geophys. Res.Atmos., 114, D09204, https://doi.org/10.1029/2008JD011112, 2009.

Bond, T. C., Zarzycki, C., Flanner, M. G., and Koch, D. M.: Quantifying immediate radiative forcing by black carbon and organic matter with the Specific Forcing Pulse, Atmos. Chem. Phys., 11, 1505-1525, https://doi.org/10.5194/acp-11-1505-2011, 2011.

Brito, J., Rizzo, L. V., Morgan, W. T., Coe, H., Johnson, B., Haywood, J., Longo, K., Freitas, S., Andreae, M. O., and Artaxo, P.: Ground-based aerosol characterization during the South American Biomass Burning Analysis (SAMBBA) field experiment, Atmos. Chem. Phys., 14, 12069-12083, https://doi.org/10.5194/acp-14-12069-2014, 2014.

Canagaratna, M. R., Jimenez, J. L., Kroll, J. H., Chen, Q., Kessler, S. H., Massoli, P., Hildebrandt Ruiz, L., Fortner, E., Williams, L. R., Wilson, K. R., Surratt, J. D., Donahue, N. M., Jayne, J. T., and Worsnop, D. R.: Elemental ratio measurements of organic compounds using aerosol mass spectrometry: characterization, improved calibration, and implications, Atmos. Chem. Phys., 15, 253-272, https://doi.org/10.5194/acp-15-253-2015, 2015. 
Chakrabarty, R. K., Moosmüller, H., Chen, L.-W. A., Lewis, K., Arnott, W. P., Mazzoleni, C., Dubey, M. K., Wold, C. E., Hao, W. M., and Kreidenweis, S. M.: Brown carbon in tar balls from smoldering biomass combustion, Atmos. Chem. Phys., 10, 6363 6370, https://doi.org/10.5194/acp-10-6363-2010, 2010.

Chakraborty, S., Schiro, K. A., Fu, R., and Neelin, J. D.: On the role of aerosols, humidity, and vertical wind shear in the transition of shallow-to-deep convection at the Green Ocean Amazon 2014/5 site, Atmos. Chem. Phys., 18, 11135-11148, https://doi.org/10.5194/acp-18-11135-2018, 2018.

Chen, Q., Farmer, D. K., Schneider, J., Zorn, S. R., Heald, C. L., Karl, T. G., Guenther, A., Allan, J. D., Robinson, N., Coe, H., Kimmel, J. R., Pauliquevis, T., Borrmann, S., Pöschl, U., Andreae, M. O., Artaxo, P., Jimenez, J. L., and Martin, S. T.: Mass spectral characterization of submicron biogenic organic particles in the Amazon Basin, Geophys. Res. Lett., 36, L20806, https://doi.org/10.1029/2009GL039880, 2009.

Cirino, G. G., Brito, J., Barbosa, H. M. J., Rizzo, L. V., Tunved, P., de Sá, S. S., Jimenez, J. L., Palm, B. B., Carbone, S., Lavric, J., Souza, R. A. F., Wolff, S., Walter, D., Tota, J., Oliveira, M. B. L., Martin, S. T., and Artaxo, P.: Observations of Manaus urban plume evolution and interaction with biogenic emissions in GoAmazon 2014/5, Atmos. Environ., 191, 513-524, https://doi.org/10.1016/j.atmosenv.2018.08.031, 2018.

Claeys, M., Vermeylen, R., Yasmeen, F., Gómez-González, Y., Chi, X., Maenhaut, W., Mészáros, T., and Salma, I.: Chemical characterisation of humic-like substances from urban, rural and tropical biomass burning environments using liquid chromatography with UV/vis photodiode array detection and electrospray ionisation mass spectrometry, Environ. Chem., 9, 3, 273-284, https://doi.org/10.1071/EN11163, 2012.

Collaud Coen, M., Weingartner, E., Apituley, A., Ceburnis, D., Fierz-Schmidhauser, R., Flentje, H., Henzing, J. S., Jennings, S. G., Moerman, M., Petzold, A., Schmid, O., and Baltensperger, U.: Minimizing light absorption measurement artifacts of the Aethalometer: evaluation of five correction algorithms, Atmos. Meas. Tech., 3, 457-474, https://doi.org/10.5194/amt-3-4572010, 2010.

Collier, S., Zhou, S., Onasch, T. B., Jaffe, D. A., Kleinman, L., Sedlacek, A. J., Briggs, N. L., Hee, J., Fortner, E., Shilling, J. E., Worsnop, D., Yokelson, R. J., Parworth, C., Ge, X., Xu, J., Butterfield, Z., Chand, D., Dubey, M. K., Pekour, M. S., Springston, S., and Zhang, Q.: Regional influence of aerosol emissions from wildfires driven by combustion efficiency: insights from the BBOP campaign, Environ. Sci. Technol., 50, 8613-8622, https://doi.org/10.1021/acs.est.6b01617, 2016.

Crutzen, P. J. and Andreae, M. O.: Biomass burning in the tropics: impact on atmospheric chemistry and biogeochemical cycles, Science, 250, 1669-1678, https://doi.org/10.1126/science.250.4988.1669, 1990.

Cubison, M. J., Ortega, A. M., Hayes, P. L., Farmer, D. K., Day, D., Lechner, M. J., Brune, W. H., Apel, E., Diskin, G. S., Fisher, J. A., Fuelberg, H. E., Hecobian, A., Knapp, D. J., Mikoviny, T., Riemer, D., Sachse, G. W., Sessions, W., Weber, R. J., Weinheimer, A. J., Wisthaler, A., and Jimenez, J. L.: Effects of aging on organic aerosol from open biomass burning smoke in aircraft and laboratory studies, Atmos. Chem. Phys., 11, 12049-12064, https://doi.org/10.5194/acp-11-12049-2011, 2011.
Davidson, E. A., de Araújo, A. C., Artaxo, P., Balch, J. K., Brown, I. F., Bustamante, M. M. C., Coe, M. T., DeFries, R. S., Keller, M., and Longo, M.: The Amazon basin in transition, Nature, 481, 321-328, https://doi.org/10.1038/nature10717, 2012.

DeCarlo, P. F., Kimmel, J. R., Trimborn, A., Northway, M. J., Jayne, J. T., Aiken, A. C., Gonin, M., Fuhrer, K., Horvath, T., Docherty, K. S., Worsnop, D. R., and Jimenez, J. L.: Field-deployable, high-resolution, time-of-flight aerosol mass spectrometer, Anal. Chem., 78, 8281-8289, https://doi.org/10.1021/ac061249n, 2006.

De Haan, D. O., Corrigan, A. L., Tolbert, M. A., Jimenez, J. L., Wood, S. E., and Turley, J. J.: Secondary organic aerosol formation by self-reactions of methylglyoxal and glyoxal in evaporating droplets, Environ. Sci. Technol., 43, 8184-8190, https://doi.org/10.1021/es902152t, 2009.

de Sá, S. S., Palm, B. B., Campuzano-Jost, P., Day, D. A., Newburn, M. K., Hu, W., Isaacman-VanWertz, G., Yee, L. D., Thalman, R., Brito, J., Carbone, S., Artaxo, P., Goldstein, A. H., Manzi, A. O., Souza, R. A. F., Mei, F., Shilling, J. E., Springston, S. R., Wang, J., Surratt, J. D., Alexander, M. L., Jimenez, J. L., and Martin, S. T.: Influence of urban pollution on the production of organic particulate matter from isoprene epoxydiols in central Amazonia, Atmos. Chem. Phys., 17, 6611-6629, https://doi.org/10.5194/acp-17-6611-2017, 2017.

de Sá, S. S., Palm, B. B., Campuzano-Jost, P., Day, D. A., Hu, W., Isaacman-VanWertz, G., Yee, L. D., Brito, J., Carbone, S., Ribeiro, I. O., Cirino, G. G., Liu, Y., Thalman, R., Sedlacek, A., Funk, A., Schumacher, C., Shilling, J. E., Schneider, J., Artaxo, P., Goldstein, A. H., Souza, R. A. F., Wang, J., McKinney, K. A., Barbosa, H., Alexander, M. L., Jimenez, J. L., and Martin, S. T. Urban influence on the concentration and composition of submicron particulate matter in central Amazonia, Atmos. Chem. Phys., 18, 12185-12206, https://doi.org/10.5194/acp-18-121852018, 2018.

Desyaterik, Y., Sun, Y., Shen, X., Lee, T., Wang, X., Wang, T., and Collett, J. L.: Speciation of "brown" carbon in cloud water impacted by agricultural biomass burning in eastern China, J. Geophys. Res.-Atmos., 118, 7389-7399, https://doi.org/10.1002/jgrd.50561, 2013.

Draxler, R. and Hess, G.: An overview of the HYSPLIT_4 modeling system for trajectories, dispersion, and deposition, Aust. Meteorol. Mag., 47, 295-308, https://doi.org/10.5194/acp-13-86072013, 1998.

Ealo, M., Alastuey, A., Pérez, N., Ripoll, A., Querol, X., and Pandolfi, M.: Impact of aerosol particle sources on optical properties in urban, regional and remote areas in the northwestern Mediterranean, Atmos. Chem. Phys., 18, 1149-1169, https://doi.org/10.5194/acp-18-1149-2018, 2018.

Echalar, F., Artaxo, P., Martins, J. V., Yamasoe, M., Gerab, F., Maenhaut, W., and Holben, B.: Long-term monitoring of atmospheric aerosols in the Amazon Basin: Source identification and apportionment, J. Geophys. Res.-Atmos., 103, 31849-31864, https://doi.org/10.1029/98JD01749, 1998.

Farmer, D. K., Matsunaga, A., Docherty, K. S., Surratt, J. D., Seinfeld, J. H., Ziemann, P. J., and Jimenez, J. L.: Response of an aerosol mass spectrometer to organonitrates and organosulfates and implications for atmospheric chemistry, P. Natl. Acad. Sci. USA, 107, 6670-6675, https://doi.org/10.1073/pnas.0912340107, 2010. 
Feng, Y., Ramanathan, V., and Kotamarthi, V. R.: Brown carbon: a significant atmospheric absorber of solar radiation?, Atmos. Chem. Phys., 13, 8607-8621, https://doi.org/10.5194/acp13-8607-2013, 2013.

Fiedler, V., Arnold, F., Ludmann, S., Minikin, A., Hamburger, T., Pirjola, L., Dörnbrack, A., and Schlager, H.: African biomass burning plumes over the Atlantic: aircraft based measurements and implications for $\mathrm{H}_{2} \mathrm{SO}_{4}$ and $\mathrm{HNO}_{3}$ mediated smoke particle activation, Atmos. Chem. Phys., 11, 3211-3225, https://doi.org/10.5194/acp-11-3211-2011, 2011.

Flores, J. M., Washenfelder, R., Adler, G., Lee, H., Segev, L., Laskin, J., Laskin, A., Nizkorodov, S., Brown, S., and Rudich, Y.: Complex refractive indices in the near-ultraviolet spectral region of biogenic secondary organic aerosol aged with ammonia, Phys. Chem. Chem. Phys., 16, 10629-10642, https://doi.org/10.1039/C4CP01009D, 2014.

Forrister, H., Liu, J., Scheuer, E., Dibb, J., Ziemba, L., Thornhill, K. L., Anderson, B., Diskin, G., Perring, A. E., Schwarz, J. P., Campuzano-Jost, P., Day, D. A., Palm, B. B., Jimenez, J. L., Nenes, A., and Weber, R. J.: Evolution of brown carbon in wildfire plumes, Geophys. Res. Lett., 42, 4623-4630, https://doi.org/10.1002/2015GL063897, 2015.

Fry, J. L., Kiendler-Scharr, A., Rollins, A. W., Wooldridge, P. J., Brown, S. S., Fuchs, H., Dubé, W., Mensah, A., dal Maso, M., Tillmann, R., Dorn, H.-P., Brauers, T., and Cohen, R. C.: Organic nitrate and secondary organic aerosol yield from $\mathrm{NO}_{3}$ oxidation of $\beta$-pinene evaluated using a gas-phase kinetics/aerosol partitioning model, Atmos. Chem. Phys., 9, 14311449, https://doi.org/10.5194/acp-9-1431-2009, 2009.

Fry, J. L., Draper, D. C., Zarzana, K. J., Campuzano-Jost, P., Day, D. A., Jimenez, J. L., Brown, S. S., Cohen, R. C., Kaser, L., Hansel, A., Cappellin, L., Karl, T., Hodzic Roux, A., Turnipseed, A., Cantrell, C., Lefer, B. L., and Grossberg, N.: Observations of gas- and aerosol-phase organic nitrates at BEACHON-RoMBAS 2011, Atmos. Chem. Phys., 13, 85858605, https://doi.org/10.5194/acp-13-8585-2013, 2013.

Fuentes, J. D., Chamecki, M., Santos, R. M. N. d., Randow, C. V., Stoy, P. C., Katul, G., Fitzjarrald, D., Manzi, A., Gerken, T., Trowbridge, A., Freire, L. S., Ruiz-Plancarte, J., Maia, J. M. F., Tóta, J., Dias, N., Fisch, G., Schumacher, C., Acevedo, O., Mercer, J. R., and Yañez-Serrano, A. M.: Linking meteorology, turbulence, and air chemistry in the Amazon rain forest, B. Am. Meteorol. Soc., 97, 2329-2342, https://doi.org/10.1175/bams-d15-00152.1, 2016.

Fuzzi, S., Decesari, S., Facchini, M. C., Cavalli, F., Emblico, L., Mircea, M., Andreae, M. O., Trebs, I., Hoffer, A. s., Guyon, P., Artaxo, P., Rizzo, L. V., Lara, L. L., Pauliquevis, T., Maenhaut, W., Raes, N., Chi, X., Mayol-Bracero, O. L., Soto-García, L. L., Claeys, M., Kourtchev, I., Rissler, J., Swietlicki, E., Tagliavini, E., Schkolnik, G., Falkovich, A. H., Rudich, Y., Fisch, G., and Gatti, L. V.: Overview of the inorganic and organic composition of size-segregated aerosol in Rondonia, Brazil, from the biomassburning period to the onset of the wet season, J. Geophys. Res.Atmos., 112, D01201, https://doi.org/10.1029/2005JD006741, 2007.

Gilardoni, S., Massoli, P., Paglione, M., Giulianelli, L., Carbone, C., Rinaldi, M., Decesari, S., Sandrini, S., Costabile, F., Gobbi, G. P., Pietrogrande, M. C., Visentin, M., Scotto, F., Fuzzi, S., and Facchini, M. C.: Direct observa- tion of aqueous secondary organic aerosol from biomassburning emissions, P. Natl. Acad. Sci. USA, 113, 10013-10018, https://doi.org/10.1073/pnas.1602212113, 2016.

Glasius, M., Bering, M. S., Yee, L. D., de Sá, S. S., IsaacmanVanWertz, G., Wernis, R. A., Barbosa, H. M. J., Alexander, M. L., Palm, B. B., Hu, W., Campuzano-Jost, P., Day, D. A., Jimenez, J. L., Shrivastava, M., Martin, S. T., and Goldstein, A. H.: Organosulfates in aerosols downwind of an urban region in central Amazon, Environ. Sci.-Proc. Imp., 20, 1546-1558, https://doi.org/10.1039/C8EM00413G, 2018.

Gonçalves, W. A., Machado, L. A. T., and Kirstetter, P.-E.: Influence of biomass aerosol on precipitation over the Central Amazon: an observational study, Atmos. Chem. Phys., 15, 6789-6800, https://doi.org/10.5194/acp-15-6789-2015, 2015.

Graber, E. R. and Rudich, Y.: Atmospheric HULIS: How humiclike are they? A comprehensive and critical review, Atmos. Chem. Phys., 6, 729-753, https://doi.org/10.5194/acp-6-7292006, 2006.

Hand, J. L. and Malm, W. C.: Review of aerosol mass scattering efficiencies from ground-based measurements since 1990, J. Geophys. Res.-Atmos., 112, D16203, https://doi.org/10.1029/2007JD008484, 2007.

Hansen, J., Sato, M., and Ruedy, R.: Radiative forcing and climate response, J. Geophys. Res.-Atmos., 102, 6831-6864, https://doi.org/10.1029/96JD03436, 1997.

Hems, R. F. and Abbatt, J. P. D.: Aqueous phase photo-oxidation of brown carbon nitrophenols: reaction kinetics, mechanism, and evolution of light absorption, ACS Earth Space Chem., 2, 225234, https://doi.org/10.1021/acsearthspacechem.7b00123, 2018.

Hoffer, A., Gelencsér, A., Guyon, P., Kiss, G., Schmid, O., Frank, G. P., Artaxo, P., and Andreae, M. O.: Optical properties of humiclike substances (HULIS) in biomass-burning aerosols, Atmos. Chem. Phys., 6, 3563-3570, https://doi.org/10.5194/acp-6-35632006, 2006.

Holben, B. N., Setzer, A., Eck, T. F., Pereira, A., and Slutsker, I.: Effect of dry-season biomass burning on Amazon basin aerosol concentrations and optical properties, 1992-1994, J. Geophys. Res.-Atmos., 101, 19465-19481, https://doi.org/10.1029/96JD01114, 1996.

Hu, W., Palm, B. B., Day, D. A., Campuzano-Jost, P., Krechmer, J. E., Peng, Z., de Sá, S. S., Martin, S. T., Alexander, M. L., Baumann, K., Hacker, L., Kiendler-Scharr, A., Koss, A. R., de Gouw, J. A., Goldstein, A. H., Seco, R., Sjostedt, S. J., Park, J.-H., Guenther, A. B., Kim, S., Canonaco, F., Prévôt, A. S. H., Brune, W. H., and Jimenez, J. L.: Volatility and lifetime against $\mathrm{OH}$ heterogeneous reaction of ambient isoprene-epoxydiolsderived secondary organic aerosol (IEPOX-SOA), Atmos. Chem. Phys., 16, 11563-11580, https://doi.org/10.5194/acp-16-115632016, 2016.

INPE: Instituto Nacional de Pesquisas Espaciais: Banco de dados de queimadas, available at: http://www.inpe.br/queimadas/ bdqueimadas/, last access: 1 February 2018.

IPCC: Summary for policymakers, in: Climate Change 2013 - The Physical Science Basis. Contribution of Working Group I to the Fifth Assessment Report of the Intergovernmental Panel on Climate Change, edited by: Stocker, T. F., Qin, D., Plattner, G.-K., Tignor, M., Allen, S. K., Boschung, J., Nauels, A., Xia, Y., Bex, V., and Midgley, P. M., Cambridge University Press, Cambridge, UK, and New York, NY, USA, Cambridge, 2013. 
Isaacman-VanWertz, G., Yee, L. D., Kreisberg, N. M., Wernis, R., Moss, J. A., Hering, S. V., de Sá, S. S., Martin, S. T., Alexander, M. L., Palm, B. B., Hu, W., Campuzano-Jost, P., Day, D. A., Jimenez, J. L., Riva, M., Surratt, J. D., Viegas, J., Manzi, A., Edgerton, E., Baumann, K., Souza, R., Artaxo, P., and Goldstein, A. H.: Ambient gas-particle partitioning of tracers for biogenic oxidation, Environ. Sci. Technol., 50, 9952-9962, https://doi.org/10.1021/acs.est.6b01674, 2016.

Jen, C. N., Hatch, L. E., Selimovic, V., Yokelson, R. J., Weber, R., Fernandez, A. E., Kreisberg, N. M., Barsanti, K. C., and Goldstein, A. H.: Speciated and total emission factors of particulate organics from burning western US wildland fuels and their dependence on combustion efficiency, Atmos. Chem. Phys., 19, 1013-1026, https://doi.org/10.5194/acp-19-1013-2019, 2019.

Jiang, X., Wiedinmyer, C., and Carlton, A. G.: Aerosols from fires: an examination of the effects on ozone photochemistry in the western United States, Environ. Sci. Technol., 46, 11878-11886, https://doi.org/10.1021/es301541k, 2012.

Jimenez, J. L., Canagaratna, M. R., Donahue, N. M., Prevot, A. S. H., Zhang, Q., Kroll, J. H., DeCarlo, P. F., Allan, J. D., Coe, H., Ng, N. L., Aiken, A. C., Docherty, K. S., Ulbrich, I. M., Grieshop, A. P., Robinson, A. L., Duplissy, J., Smith, J. D., Wilson, K. R., Lanz, V. A., Hueglin, C., Sun, Y. L., Tian, J., Laaksonen, A., Raatikainen, T., Rautiainen, J., Vaattovaara, P., Ehn, M., Kulmala, M., Tomlinson, J. M., Collins, D. R., Cubison, M. J., Dunlea, J., Huffman, J. A., Onasch, T. B., Alfarra, M. R., Williams, P. I., Bower, K., Kondo, Y., Schneider, J., Drewnick, F., Borrmann, S., Weimer, S., Demerjian, K., Salcedo, D., Cottrell, L., Griffin, R., Takami, A., Miyoshi, T., Hatakeyama, S., Shimono, A., Sun, J. Y., Zhang, Y. M., Dzepina, K., Kimmel, J. R., Sueper, D., Jayne, J. T., Herndon, S. C., Trimborn, A. M., Williams, L. R., Wood, E. C., Middlebrook, A. M., Kolb, C. E., Baltensperger, U., and Worsnop, D. R.: Evolution of organic aerosols in the atmosphere, Science, 326, 1525-1529, https://doi.org/10.1126/science.1180353, 2009.

Jordan, A., Haidacher, S., Hanel, G., Hartungen, E., Märk, L., Seehauser, H., Schottkowsky, R., Sulzer, P., and Märk, T. D.: A high resolution and high sensitivity proton-transfer-reaction time-offlight mass spectrometer (PTR-TOF-MS), Int. J. Mass Spectrom., 286, 122-128, https://doi.org/10.1016/j.ijms.2009.07.005, 2009.

Kahnt, A., Behrouzi, S., Vermeylen, R., Safi Shalamzari, M., Vercauteren, J., Roekens, E., Claeys, M., and Maenhaut, W.: One-year study of nitro-organic compounds and their relation to wood burning in $\mathrm{PM}_{10}$ aerosol from a rural site in Belgium, Atmos. Environ., 81, 561-568, https://doi.org/10.1016/j.atmosenv.2013.09.041, 2013.

Kaufman, Y. J., Hobbs, P. V., Kirchhoff, V. W. J. H., Artaxo, P., Remer, L. A., Holben, B. N., King, M. D., Ward, D. E., Prins, E. M., Longo, K. M., Mattos, L. F., Nobre, C. A., Spinhirne, J. D., Ji, Q., Thompson, A. M., Gleason, J. F., Christopher, S. A., and Tsay, S. C.: Smoke, Clouds, and Radiation-Brazil (SCARB) experiment, J. Geophys. Res.-Atmos., 103, 31783-31808, https://doi.org/10.1029/98JD02281, 1998.

Kitanovski, Z., Grgić, I., Vermeylen, R., Claeys, M., and Maenhaut, W.: Liquid chromatography tandem mass spectrometry method for characterization of monoaromatic nitro-compounds in atmospheric particulate matter, J. Chromatogr. A, 1268, 35-43, https://doi.org/10.1016/j.chroma.2012.10.021, 2012.
Knote, C., Hodzic, A., and Jimenez, J. L.: The effect of dry and wet deposition of condensable vapors on secondary organic aerosols concentrations over the continental US, Atmos. Chem. Phys., 15, 1-18, https://doi.org/10.5194/acp-15-1-2015, 2015.

Kuhn, U., Ganzeveld, L., Thielmann, A., Dindorf, T., Schebeske, G., Welling, M., Sciare, J., Roberts, G., Meixner, F. X., Kesselmeier, J., Lelieveld, J., Kolle, O., Ciccioli, P., Lloyd, J., Trentmann, J., Artaxo, P., and Andreae, M. O.: Impact of Manaus City on the Amazon Green Ocean atmosphere: ozone production, precursor sensitivity and aerosol load, Atmos. Chem. Phys., 10, 9251-9282, https://doi.org/10.5194/acp-10-9251-2010, 2010.

Lack, D. A., Bahreini, R., Langridge, J. M., Gilman, J. B., and Middlebrook, A. M.: Brown carbon absorption linked to organic mass tracers in biomass burning particles, Atmos. Chem. Phys., 13, 2415-2422, https://doi.org/10.5194/acp-132415-2013, 2013.

Laskin, A., Laskin, J., and Nizkorodov, S. A.: Chemistry of atmospheric brown carbon, Chem. Rev., 115, 4335-4382, https://doi.org/10.1021/cr5006167, 2015.

Lee, A. K. Y., Zhao, R., Li, R., Liggio, J., Li, S.-M., and Abbatt, J. P. D.: Formation of light absorbing organo-nitrogen species from evaporation of droplets containing glyoxal and ammonium sulfate, Environ. Sci. Technol., 47, 12819-12826, https://doi.org/10.1021/es402687w, 2013.

Lee, H. J., Aiona, P. K., Laskin, A., Laskin, J., and Nizkorodov, S. A.: Effect of solar radiation on the optical properties and molecular composition of laboratory proxies of atmospheric brown carbon, Environ. Sci. Technol., 48, 10217-10226, https://doi.org/10.1021/es502515r, 2014.

Li, G., Bei, N., Tie, X., and Molina, L. T.: Aerosol effects on the photochemistry in Mexico City during MCMA2006/MILAGRO campaign, Atmos. Chem. Phys., 11, 51695182, https://doi.org/10.5194/acp-11-5169-2011, 2011.

Lin, J. C., Matsui, T., Pielke, R. A., and Kummerow, C.: Effects of biomass-burning-derived aerosols on precipitation and clouds in the Amazon Basin: a satellite-based empirical study, J. Geophys. Res.-Atmos., 111, D19204, https://doi.org/10.1029/2005JD006884, 2006.

Lin, P., Aiona, P. K., Li, Y., Shiraiwa, M., Laskin, J., Nizkorodov, S. A., and Laskin, A.: Molecular characterization of brown carbon in biomass burning aerosol particles, Environ. Sci. Technol., 50, 11815-11824, https://doi.org/10.1021/acs.est.6b03024, 2016.

Lin, Y.-H., Budisulistiorini, S. H., Chu, K., Siejack, R. A., Zhang, H., Riva, M., Zhang, Z., Gold, A., Kautzman, K. E., and Surratt, J. D.: Light-absorbing oligomer formation in secondary organic aerosol from reactive uptake of isoprene epoxydiols, Environ. Sci. Technol., 48, 12012-12021, https://doi.org/10.1021/es503142b, 2014.

Liu, P., Zhang, Y., and Martin, S. T.: Complex refractive indices of thin films of secondary organic materials by spectroscopic ellipsometry from 220 to $1200 \mathrm{~nm}$, Environ. Sci. Technol., 47, 13594-13601, https://doi.org/10.1021/es403411e, 2013.

Liu, P. F., Abdelmalki, N., Hung, H.-M., Wang, Y., Brune, W. H., and Martin, S. T.: Ultraviolet and visible complex refractive indices of secondary organic material produced by photooxidation of the aromatic compounds toluene and $m$-xylene, Atmos. Chem. Phys., 15, 1435-1446, https://doi.org/10.5194/acp15-1435-2015, 2015. 
Liu, S., Shilling, J. E., Song, C., Hiranuma, N., Zaveri, R. A., and Russell, L. M.: Hydrolysis of organonitrate functional groups in aerosol particles, Aerosol Sci. Tech., 46, 1359-1369, https://doi.org/10.1080/02786826.2012.716175, 2012.

Liu, Y., Brito, J., Dorris, M. R., Rivera-Rios, J. C., Seco, R., Bates, K. H., Artaxo, P., Duvoisin, S., Keutsch, F. N., Kim, S., Goldstein, A. H., Guenther, A. B., Manzi, A. O., Souza, R. A. F., Springston, S. R., Watson, T. B., McKinney, K. A., and Martin, S. T.: Isoprene photochemistry over the Amazon rain forest, P. Natl. Acad. Sci. USA, 113, 6125-6130, https://doi.org/10.1073/pnas.1524136113, 2016.

Ma, L. and Thompson, J. E.: Optical properties of dispersed aerosols in the near ultraviolet $(355 \mathrm{~nm})$ : measurement approach and initial data, Anal. Chem., 84, 5611-5617, https://doi.org/10.1021/ac3005814, 2012

Mace, K. A., Artaxo, P., and Duce, R. A.: Water-soluble organic nitrogen in Amazon Basin aerosols during the dry (biomass burning) and wet seasons, J. Geophys. Res.-Atmos., 108, 4512, https://doi.org/10.1029/2003JD003557, 2003.

Machado, L. A. T., Laurent, H., Dessay, N., and Miranda, I.: Seasonal and diurnal variability of convection over the Amazonia: a comparison of different vegetation types and large scale forcing, Theor. App. Climatol., 78, 61-77, https://doi.org/10.1007/s00704-004-0044-9, 2004.

Machado, L. A. T., Dias, M. A. F. S., Morales, C., Fisch, G., Vila, D., Albrecht, R., Goodman, S. J., Calheiros, A. J. P., Biscaro, T., Kummerow, C., Cohen, J., Fitzjarrald, D., Nascimento, E. L., Sakamoto, M. S., Cunningham, C., Chaboureau, J.-P., Petersen, W. A., Adams, D. K., Baldini, L., Angelis, C. F., Sapucci, L. F., Salio, P., Barbosa, H. M. J., Landulfo, E., Souza, R. A. F., Blakeslee, R. J., Bailey, J., Freitas, S., Lima, W. F. A., and Tokay, A.: The Chuva Project: how does convection vary across Brazil?, B. Am. Meteorol. Soc., 95, 1365-1380, https://doi.org/10.1175/bams-d-13-00084.1, 2014.

Maenhaut, W., Fernández-Jiménez, M. T., and Artaxo, P.: Longterm study of atmospheric aerosols in Cuiabá, Brazil: multielemental composition, sources and source apportionment, J. Aerosol Sci., 30, S259-S260, https://doi.org/10.1016/S00218502(99)80141-4, 1999.

Martin, S. T., Andreae, M. O., Artaxo, P., Baumgardner, D., Chen, Q., Goldstein, A. H., Guenther, A., Heald, C. L., Mayol-Bracero, O. L., McMurry, P. H., Pauliquevis, T., Pöschl, U., Prather, K. A., Roberts, G. C., Saleska, S. R., Dias, M. A. S., Spracklen, D. V., Swietlicki, E., and Trebs, I.: Sources and properties of Amazonian aerosol particles, Rev. Geophys., 48, RG2002, https://doi.org/10.1029/2008RG000280, 2010a.

Martin, S. T., Andreae, M. O., Althausen, D., Artaxo, P., Baars, H., Borrmann, S., Chen, Q., Farmer, D. K., Guenther, A., Gunthe, S. S., Jimenez, J. L., Karl, T., Longo, K., Manzi, A., Müller, T., Pauliquevis, T., Petters, M. D., Prenni, A. J., Pöschl, U., Rizzo, L. V., Schneider, J., Smith, J. N., Swietlicki, E., Tota, J., Wang, J., Wiedensohler, A., and Zorn, S. R.: An overview of the Amazonian Aerosol Characterization Experiment 2008 (AMAZE-08), Atmos. Chem. Phys., 10, 1141511438, https://doi.org/10.5194/acp-10-11415-2010, $2010 \mathrm{~b}$.

Martin, S. T., Artaxo, P., Machado, L. A. T., Manzi, A. O., Souza, R. A. F., Schumacher, C., Wang, J., Andreae, M. O., Barbosa, H. M. J., Fan, J., Fisch, G., Goldstein, A. H., Guenther, A., Jimenez, J. L., Pöschl, U., Silva Dias, M. A., Smith, J. N., and Wendisch, M.:
Introduction: Observations and Modeling of the Green Ocean Amazon (GoAmazon2014/5), Atmos. Chem. Phys., 16, 47854797, https://doi.org/10.5194/acp-16-4785-2016, 2016.

Martin, S. T., Artaxo, P., Machado, L., Manzi, A. O., Souza, R. A. F., Schumacher, C., Wang, J., Biscaro, T., Brito, J., Calheiros, A., Jardine, K., Medeiros, A., Portela, B., Sá, S. S. d., Adachi, K., Aiken, A. C., Albrecht, R., Alexander, L., Andreae, M. O., Barbosa, H. M. J., Buseck, P., Chand, D., Comstock, J. M., Day, D. A., Dubey, M., Fan, J., Fast, J., Fisch, G., Fortner, E., Giangrande, S., Gilles, M., Goldstein, A. H., Guenther, A., Hubbe, J., Jensen, M., Jimenez, J. L., Keutsch, F. N., Kim, S., Kuang, C., Laskin, A., McKinney, K., Mei, F., Miller, M., Nascimento, R., Pauliquevis, T., Pekour, M., Peres, J., Petäjä, T., Pöhlker, C., Pöschl, U., Rizzo, L., Schmid, B., Shilling, J. E., Dias, M. A. S., Smith, J. N., Tomlinson, J. M., Tóta, J., and Wendisch, M.: The Green Ocean Amazon Experiment (GoAmazon2014/5) observes pollution affecting gases, aerosols, clouds, and rainfall over the rain forest, B. Am. Meteorol. Soc., 98, 981-997, https://doi.org/10.1175/bams-d-15-00221.1, 2017.

Middlebrook, A. M., Bahreini, R., Jimenez, J. L., and Canagaratna, M. R.: Evaluation of composition-dependent collection efficiencies for the aerodyne aerosol mass spectrometer using field data, Aerosol Sci. Tech., 46, 258-271, https://doi.org/10.1080/02786826.2011.620041, 2012.

Mohr, C., Lopez-Hilfiker, F. D., Zotter, P., Prévôt, A. S. H., Xu, L., Ng, N. L., Herndon, S. C., Williams, L. R., Franklin, J. P., Zahniser, M. S., Worsnop, D. R., Knighton, W. B., Aiken, A. C., Gorkowski, K. J., Dubey, M. K., Allan, J. D., and Thornton, J. A.: Contribution of nitrated phenols to wood burning brown carbon light absorption in Detling, United Kingdom during Winter time, Environ. Sci. Technol., 47, 6316-6324, https://doi.org/10.1021/es400683v, 2013.

Moosmüller, H., Chakrabarty, R. K., and Arnott, W. P.: Aerosol light absorption and its measurement: A review, J. Quant. Spectrosc. Ra., 110, 844-878, https://doi.org/10.1016/j.jqsrt.2009.02.035, 2009.

Morgan, W. T., Allan, J. D., Flynn, M., Darbyshire, E., Hodgson, A., Johnson, B. T., Haywood, J. M., Freitas, S., Longo, K., Artaxo, P., and Coe, H.: Overview of the South American biomass burning analysis (SAMBBA) field experiment, AIP Conf. Proc., 1527, 587-590, https://doi.org/10.1063/1.4803339, 2013.

Mukai, H. and Ambe, Y.: Characterization of a humic acidlike brown substance in airborne particulate matter and tentative identification of its origin, Atmos. Environ., 20, 813-819, https://doi.org/10.1016/0004-6981(86)90265-9, 1986.

Myhre, G., Samset, B. H., Schulz, M., Balkanski, Y., Bauer, S., Berntsen, T. K., Bian, H., Bellouin, N., Chin, M., Diehl, T., Easter, R. C., Feichter, J., Ghan, S. J., Hauglustaine, D., Iversen, T., Kinne, S., Kirkevåg, A., Lamarque, J.-F., Lin, G., Liu, X., Lund, M. T., Luo, G., Ma, X., van Noije, T., Penner, J. E., Rasch, P. J., Ruiz, A., Seland, Ø., Skeie, R. B., Stier, P., Takemura, T., Tsigaridis, K., Wang, P., Wang, Z., Xu, L., Yu, H., Yu, F., Yoon, J.-H., Zhang, K., Zhang, H., and Zhou, C.: Radiative forcing of the direct aerosol effect from AeroCom Phase II simulations, Atmos. Chem. Phys., 13, 1853-1877, https://doi.org/10.5194/acp13-1853-2013, 2013.

Nakayama, T., Kondo, Y., Moteki, N., Sahu, L. K., Kinase, T., Kita, K., and Matsumi, Y.: Size-dependent correction factors for absorption measurements using filter-based photome- 
ters: PSAP and COSMOS, J. Aerosol Sci., 41, 333-343, https://doi.org/10.1016/j.jaerosci.2010.01.004, 2010.

Nakayama, T., Sato, K., Matsumi, Y., Imamura, T., Yamazaki, A., and Uchiyama, A.: Wavelength dependence of refractive index of secondary organic aerosols generated during the ozonolysis and photooxidation of $\alpha$-pinene, SOLA, 8, 119-123, https://doi.org/10.2151/sola.2012-030, 2012.

Nepstad, D. C., Verssimo, A., Alencar, A., Nobre, C., Lima, E., Lefebvre, P., Schlesinger, P., Potter, C., Moutinho, P., Mendoza, E., Cochrane, M., and Brooks, V.: Large-scale impoverishment of Amazonian forests by logging and fire, Nature, 398, 505-508, https://doi.org/10.1038/19066, 1999.

Ng, N. L., Herndon, S. C., Trimborn, A., Canagaratna, M. R., Croteau, P. L., Onasch, T. B., Sueper, D., Worsnop, D. R., Zhang, Q., Sun, Y. L., and Jayne, J. T.: An Aerosol Chemical Speciation Monitor (ACSM) for routine monitoring of the composition and mass concentrations of ambient aerosol, Aerosol Sci. Tech., 45, 780-794, https://doi.org/10.1080/02786826.2011.560211, 2011.

Nguyen, T. B., Lee, P. B., Updyke, K. M., Bones, D. L., Laskin, J., Laskin, A., and Nizkorodov, S. A.: Formation of nitrogen- and sulfur-containing light-absorbing compounds accelerated by evaporation of water from secondary organic aerosols, J. Geophys. Res.-Atmos., 117, D01207, https://doi.org/10.1029/2011JD016944, 2012.

Nozière, B., Dziedzic, P., and Córdova, A.: Formation of secondary light-absorbing "fulvic-like" oligomers: A common process in aqueous and ionic atmospheric particles?, Geophys. Res. Lett., 34, L21812, https://doi.org/10.1029/2007GL031300, 2007.

Nunes, A. M. P., Silva Dias, M. A. F., Anselmo, E. M., and Morales, C. A.: Severe Convection Features in the Amazon Basin: A TRMM-Based 15-Year Evaluation, Front. Earth Sci., 4, 37, https://doi.org/10.3389/feart.2016.00037, 2016.

Palm, B. B., de Sá, S. S., Day, D. A., Campuzano-Jost, P., Hu, W., Seco, R., Sjostedt, S. J., Park, J.-H., Guenther, A. B., Kim, S., Brito, J., Wurm, F., Artaxo, P., Thalman, R., Wang, J., Yee, L. D., Wernis, R., Isaacman-VanWertz, G., Goldstein, A. H., Liu, Y., Springston, S. R., Souza, R., Newburn, M. K., Alexander, M. L., Martin, S. T., and Jimenez, J. L.: Secondary organic aerosol formation from ambient air in an oxidation flow reactor in central Amazonia, Atmos. Chem. Phys., 18, 467-493, https://doi.org/10.5194/acp-18-467-2018, 2018.

Pöhlker, M. L., Pöhlker, C., Ditas, F., Klimach, T., Hrabe de Angelis, I., Araújo, A., Brito, J., Carbone, S., Cheng, Y., Chi, X., Ditz, R., Gunthe, S. S., Kesselmeier, J., Könemann, T., Lavriç, J. V., Martin, S. T., Mikhailov, E., Moran-Zuloaga, D., Rose, D., Saturno, J., Su, H., Thalman, R., Walter, D., Wang, J., Wolff, S., Barbosa, H. M. J., Artaxo, P., Andreae, M. O., and Pöschl, U.: Longterm observations of cloud condensation nuclei in the Amazon rain forest - Part 1: Aerosol size distribution, hygroscopicity, and new model parametrizations for CCN prediction, Atmos. Chem. Phys., 16, 15709-15740, https://doi.org/10.5194/acp-16-157092016, 2016.

Pöschl, U.: Aerosol particle analysis: challenges and progress, Anal. Bioanal. Chem., 375, 30-32, https://doi.org/10.1007/s00216002-1611-5, 2003.

Powelson, M. H., Espelien, B. M., Hawkins, L. N., Galloway, M. M., and De Haan, D. O.: Brown carbon formation by aqueous-phase carbonyl compound reactions with amines and ammonium sulfate, Environ. Sci. Technol., 48, 985-993, https://doi.org/10.1021/es4038325, 2014.

Ramanathan, V. and Carmichael, G.: Global and regional climate changes due to black carbon, Nat. Geosci., 1, 221, https://doi.org/10.1038/ngeo156, 2008.

Ramanathan, V., Li, F., Ramana, M. V., Praveen, P. S., Kim, D., Corrigan, C. E., Nguyen, H., Stone, E. A., Schauer, J. J., Carmichael, G. R., Adhikary, B., and Yoon, S. C.: Atmospheric brown clouds: Hemispherical and regional variations in long-range transport, absorption, and radiative forcing, J. Geophys. Res.-Atmos., 112, D22S21, https://doi.org/10.1029/2006JD008124, 2007.

Rizzo, L. V., Correia, A. L., Artaxo, P., Procópio, A. S., and Andreae, M. O.: Spectral dependence of aerosol light absorption over the Amazon Basin, Atmos. Chem. Phys., 11, 8899-8912, https://doi.org/10.5194/acp-11-8899-2011, 2011.

Rizzo, L. V., Artaxo, P., Müller, T., Wiedensohler, A., Paixão, M., Cirino, G. G., Arana, A., Swietlicki, E., Roldin, P., Fors, E. O., Wiedemann, K. T., Leal, L. S. M., and Kulmala, M.: Long term measurements of aerosol optical properties at a primary forest site in Amazonia, Atmos. Chem. Phys., 13, 2391-2413, https://doi.org/10.5194/acp-13-2391-2013, 2013.

Romonosky, D. E., Laskin, A., Laskin, J., and Nizkorodov, S. A.: High-resolution mass spectrometry and molecular characterization of aqueous photochemistry products of common types of secondary organic aerosols, J. Phys. Chem. A, 119, 2594-2606, https://doi.org/10.1021/jp509476r, 2015.

Rummel, U., Ammann, C., Kirkman, G. A., Moura, M. A. L., Foken, T., Andreae, M. O., and Meixner, F. X.: Seasonal variation of ozone deposition to a tropical rain forest in southwest Amazonia, Atmos. Chem. Phys., 7, 5415-5435, https://doi.org/10.5194/acp7-5415-2007, 2007.

Saleh, R., Robinson, E. S., Tkacik, D. S., Ahern, A. T., Liu, S., Aiken, A. C., Sullivan, R. C., Presto, A. A., Dubey, M. K., Yokelson, R. J., Donahue, N. M., and Robinson, A. L.: Brownness of organics in aerosols from biomass burning linked to their black carbon content, Nat. Geosci., 7, 647, https://doi.org/10.1038/ngeo2220, 2014.

Saturno, J., Pöhlker, C., Massabò, D., Brito, J., Carbone, S., Cheng, Y., Chi, X., Ditas, F., Hrabě de Angelis, I., Morán-Zuloaga D., Pöhlker, M. L., Rizzo, L. V., Walter, D., Wang, Q., Artaxo, P., Prati, P., and Andreae, M. O.: Comparison of different Aethalometer correction schemes and a reference multiwavelength absorption technique for ambient aerosol data, Atmos. Meas. Tech., 10, 2837-2850, https://doi.org/10.5194/amt10-2837-2017, 2017.

Saturno, J., Holanda, B. A., Pöhlker, C., Ditas, F., Wang, Q., Moran-Zuloaga, D., Brito, J., Carbone, S., Cheng, Y., Chi, X., Ditas, J., Hoffmann, T., Hrabe de Angelis, I., Könemann, T., Lavrič, J. V., Ma, N., Ming, J., Paulsen, H., Pöhlker, M. L., Rizzo, L. V., Schlag, P., Su, H., Walter, D., Wolff, S., Zhang, Y., Artaxo, P., Pöschl, U., and Andreae, M. O.: Black and brown carbon over central Amazonia: long-term aerosol measurements at the ATTO site, Atmos. Chem. Phys., 18, 1281712843, https://doi.org/10.5194/acp-18-12817-2018, 2018 a.

Saturno, J., Ditas, F., Penning de Vries, M., Holanda, B. A., Pöhlker, M. L., Carbone, S., Walter, D., Bobrowski, N., Brito, J., Chi, X., Gutmann, A., Hrabe de Angelis, I., Machado, L. A. T., Moran-Zuloaga, D., Rüdiger, J., Schneider, J., Schulz, C., Wang, Q., Wendisch, M., Artaxo, P., Wagner, T., Pöschl, U., Andreae, 
M. O., and Pöhlker, C.: African volcanic emissions influencing atmospheric aerosols over the Amazon rain forest, Atmos. Chem. Phys., 18, 10391-10405, https://doi.org/10.5194/acp-18-103912018, 2018b.

Schmid, O., Artaxo, P., Arnott, W. P., Chand, D., Gatti, L. V., Frank, G. P., Hoffer, A., Schnaiter, M., and Andreae, M. O.: Spectral light absorption by ambient aerosols influenced by biomass burning in the Amazon Basin. I: Comparison and field calibration of absorption measurement techniques, Atmos. Chem. Phys., 6, 3443-3462, https://doi.org/10.5194/acp-6-3443-2006, 2006.

Schneider, J., Weimer, S., Drewnick, F., Borrmann, S., Helas, G., Gwaze, P., Schmid, O., Andreae, M. O., and Kirchner, U.: Mass spectrometric analysis and aerodynamic properties of various types of combustion-related aerosol particles, Int. J. Mass Spectrom., 258, 37-49, https://doi.org/10.1016/j.ijms.2006.07.008, 2006.

Sena, E. T., Artaxo, P., and Correia, A. L.: Spatial variability of the direct radiative forcing of biomass burning aerosols and the effects of land use change in Amazonia, Atmos. Chem. Phys., 13, 1261-1275, https://doi.org/10.5194/acp-13-1261-2013, 2013.

Setzer, A. W. and Pereira, M. C.: Amazonia biomass burnings in 1987 and an estimate of their tropospheric emissions, Ambio, 20, 19-22, 1991.

Sueper, D.: ToF-AMS Data Analysis Software Webpage, available at: http://cires1.colorado.edu/jimenez-group/wiki/index.php/ ToF-AMS_Analysis_Software, last access: August 2018.

Sumlin, B. J., Pandey, A., Walker, M. J., Pattison, R. S., Williams, B. J., and Chakrabarty, R. K.: Atmospheric Photooxidation Diminishes Light Absorption by Primary Brown Carbon Aerosol from Biomass Burning, Environ. Sci. Tech. Let., 4, 540-545, https://doi.org/10.1021/acs.estlett.7b00393, 2017.

Sun, H., Biedermann, L., and Bond, T. C.: Color of brown carbon: A model for ultraviolet and visible light absorption by organic carbon aerosol, Geophys. Res. Lett., 34, L17813, https://doi.org/10.1029/2007GL029797, 2007.

Thalman, R., de Sá, S. S., Palm, B. B., Barbosa, H. M. J., Pöhlker, M. L., Alexander, M. L., Brito, J., Carbone, S., Castillo, P., Day, D. A., Kuang, C., Manzi, A., Ng, N. L., Sedlacek III, A. J., Souza, R., Springston, S., Watson, T., Pöhlker, C., Pöschl, U., Andreae, M. O., Artaxo, P., Jimenez, J. L., Martin, S. T., and Wang, J.: CCN activity and organic hygroscopicity of aerosols downwind of an urban region in central Amazonia: seasonal and diel variations and impact of anthropogenic emissions, Atmos. Chem. Phys., 17, 11779-11801, https://doi.org/10.5194/acp-1711779-2017, 2017.

Ulbrich, I. M., Canagaratna, M. R., Zhang, Q., Worsnop, D. R., and Jimenez, J. L.: Interpretation of organic components from Positive Matrix Factorization of aerosol mass spectrometric data, Atmos. Chem. Phys., 9, 2891-2918, https://doi.org/10.5194/acp-92891-2009, 2009.

van Marle, M. J. E., Field, R. D., Werf, G. R., Estrada de Wagt, I. A., Houghton, R. A., Rizzo, L. V., Artaxo, P., and Tsigaridis, K.: Fire and deforestation dynamics in Amazonia (1973-2014), Global Biogeochem. Cy., 31, 24-38, https://doi.org/10.1002/2016GB005445, 2017.

Wang, X., Heald, C. L., Sedlacek, A. J., de Sá, S. S., Martin, S. T., Alexander, M. L., Watson, T. B., Aiken, A. C., Springston, S. R., and Artaxo, P.: Deriving brown carbon from multiwavelength absorption measurements: method and application to AERONET and Aethalometer observations, Atmos. Chem. Phys., 16, 12733 12752, https://doi.org/10.5194/acp-16-12733-2016, 2016.

Washenfelder, R. A., Attwood, A. R., Brock, C. A., Guo, H., Xu, L., Weber, R. J., Ng, N., Allen, H. M., Ayres, B. R., Karsten, B., Cohen, R. C., Draper, D. C., Duffey, K. C., Edgerton, E., Fry, J. L., Hu, W., Jimenez, J. L., Palm, B. B., Romer, P., and Brown, S.: Biomass burning dominates brown carbon absorption in the rural southeastern United States, Geophys. Res. Lett., 42, 653664, https://doi.org/10.1002/2014GL062444, 2015.

Weingartner, E., Saathoff, H., Schnaiter, M., Streit, N., Bitnar, B., and Baltensperger, U.: Absorption of light by soot particles: determination of the absorption coefficient by means of aethalometers, J. Aerosol Sci., 34, 1445-1463, https://doi.org/10.1016/S0021-8502(03)00359-8, 2003.

Yáñez-Serrano, A. M., Nölscher, A. C., Williams, J., Wolff, S., Alves, E., Martins, G. A., Bourtsoukidis, E., Brito, J., Jardine, K., Artaxo, P., and Kesselmeier, J.: Diel and seasonal changes of biogenic volatile organic compounds within and above an Amazonian rainforest, Atmos. Chem. Phys., 15, 3359-3378, https://doi.org/10.5194/acp-15-3359-2015, 2015.

Yang, M., Howell, S. G., Zhuang, J., and Huebert, B. J.: Attribution of aerosol light absorption to black carbon, brown carbon, and dust in China - interpretations of atmospheric measurements during EAST-AIRE, Atmos. Chem. Phys., 9, 2035-2050, https://doi.org/10.5194/acp-9-2035-2009, 2009.

Yee, L. D., Kautzman, K. E., Loza, C. L., Schilling, K. A., Coggon, M. M., Chhabra, P. S., Chan, M. N., Chan, A. W. H., Hersey, S. P., Crounse, J. D., Wennberg, P. O., Flagan, R. C., and Seinfeld, J. H.: Secondary organic aerosol formation from biomass burning intermediates: phenol and methoxyphenols, Atmos. Chem. Phys., 13, 8019-8043, https://doi.org/10.5194/acp13-8019-2013, 2013.

Yee, L. D., Isaacman-VanWertz, G., Wernis, R. A., Meng, M., Rivera, V., Kreisberg, N. M., Hering, S. V., Bering, M. S., Glasius, M., Upshur, M. A., Gray Bé, A., Thomson, R. J., Geiger, F. M., Offenberg, J. H., Lewandowski, M., Kourtchev, I., Kalberer, M., de Sá, S., Martin, S. T., Alexander, M. L., Palm, B. B., Hu, W., Campuzano-Jost, P., Day, D. A., Jimenez, J. L., Liu, Y., McKinney, K. A., Artaxo, P., Viegas, J., Manzi, A., Oliveira, M. B., de Souza, R., Machado, L. A. T., Longo, K., and Goldstein, A. H.: Observations of sesquiterpenes and their oxidation products in central Amazonia during the wet and dry seasons, Atmos. Chem. Phys., 18, 10433-10457, https://doi.org/10.5194/acp-18-104332018, 2018.

Yokelson, R. J., Karl, T., Artaxo, P., Blake, D. R., Christian, T. J., Griffith, D. W. T., Guenther, A., and Hao, W. M.: The Tropical Forest and Fire Emissions Experiment: overview and airborne fire emission factor measurements, Atmos. Chem. Phys. 7, 5175-5196, https://doi.org/10.5194/acp-7-5175-2007, 2007.

Zhao, R., Lee, A. K. Y., Huang, L., Li, X., Yang, F., and Abbatt, J. P. D.: Photochemical processing of aqueous atmospheric brown carbon, Atmos. Chem. Phys., 15, 6087-6100, https://doi.org/10.5194/acp-15-6087-2015, 2015.

Zhong, M. and Jang, M.: Light absorption coefficient measurement of SOA using a UV-Visible spectrometer connected with an integrating sphere, Atmos. Environ., 45, 4263-4271, https://doi.org/10.1016/j.atmosenv.2011.04.082, 2011.

Zhou, S., Collier, S., Jaffe, D. A., Briggs, N. L., Hee, J., Sedlacek III, A. J., Kleinman, L., Onasch, T. B., and Zhang, Q. 
Regional influence of wildfires on aerosol chemistry in the western US and insights into atmospheric aging of biomass burning organic aerosol, Atmos. Chem. Phys., 17, 2477-2493, https://doi.org/10.5194/acp-17-2477-2017, 2017. 